University of Louisville

ThinkIR: The University of Louisville's Institutional Repository

8-2021

\title{
Economic and sociological factors associate with first-year African American students' enrollment in historically Black Colleges and Universities.
}

Vickie Gale Bridgeman

University of Louisville

Follow this and additional works at: https://ir.library.louisville.edu/etd

Part of the Educational Assessment, Evaluation, and Research Commons, Educational Leadership Commons, Educational Methods Commons, Higher Education Commons, and the Secondary Education Commons

\section{Recommended Citation}

Bridgeman, Vickie Gale, "Economic and sociological factors associate with first-year African American students' enrollment in historically Black Colleges and Universities." (2021). Electronic Theses and Dissertations. Paper 3602.

https://doi.org/10.18297/etd/3602

This Doctoral Dissertation is brought to you for free and open access by ThinkIR: The University of Louisville's Institutional Repository. It has been accepted for inclusion in Electronic Theses and Dissertations by an authorized administrator of ThinkIR: The University of Louisville's Institutional Repository. This title appears here courtesy of the author, who has retained all other copyrights. For more information, please contact thinkir@louisville.edu. 
ECONOMIC AND SOCIOLOGICAL FACTORS ASSOCIATE WITH FIRST-YEAR AFRICAN AMERICAN STUDENTS' ENROLLMENT IN HISTORICALLY BLACK COLLEGES AND UNIVERSITIES

\author{
By \\ Vickie Gale Bridgeman \\ B.S., University of Louisville, 1985 \\ M.S., University of Louisville, 1993 \\ M.A., University of Louisville, 2002

\begin{abstract}
A Dissertation submitted to the faculty of the
College of Education and Human Development of the

University of Louisville in partial fulfillment of the

Requirements for the degree of
\end{abstract}

Doctor of Philosophy in Educational Leadership and Organizational Development

Department of Educational Leadership, Evaluation and Organizational Development

University of Louisville

Louisville, Kentucky

May 2021 

ECONOMIC AND SOCIOLOGICAL FACTORS ASSOCIATE WITH FIRST-YEAR AFRICAN AMERICAN STUDENTS' ENROLLMENT IN HISTORICALLY BLACK COLLEGES AND UNIVERSITIES

By

Vickie Gale Bridgeman

B.S., University of Louisville, 1985

M.S., University of Louisville, 1993

M.A., University of Louisville, 2002

A Dissertation Approved on

April 23, 2021

by the following Dissertation Committee:

Jacob Gross, Ph.D.

Amy Hirschy, Ph.D.

Ishwanzya Rivers, Ph.D.

Jeffrey Sun, Ph.D. 


\section{ACKNOWLEDGEMENTS}

Philippians 4:13 reminds me that "I can do all things through Christ who strengthens me.” I thank God for bringing me to this point in my life. The journey has been difficult, but through it all I have become a stronger person. I give thanks to Dr. Gross and to Dr. Hirschy for agreeing to serve as co-advisors for my dissertation and for their continued support throughout the last few years. They pushed me to think beyond the present. I also thank Dr. Sun and Dr. Rivers for serving on my committee and for offering me needed feedback.

I am especially grateful to my husband Alphonzo and to my daughters Shawnda and Chelsee for their continued support and encouragement. I give special thanks to Philip Ardery for editing, reading and keeping me on track, and to Stephen Leach and Dr. Gross for helping me with my statistical analysis. I thank all my family, friends and church family for your prayers, phone calls, encouragement, and support throughout this long dissertation journey. Finally, I thank my mother and father. I felt your presence each and every day, I miss you, and I know you are smiling up in heaven for your firstgeneration college graduate. 


\begin{abstract}
ECONOMIC AND SOCIOLOGICAL FACTORS ASSOCIATE WITH FIRST-YEAR AFRICAN AMERICAN STUDENTS’ ENROLLMENT IN HISTORICALLY BLACK COLLEGES AND UNIVERSITIES
\end{abstract}

\author{
Vickie Gale Bridgeman
}

April 23, 2021

Despite the long struggle to gain access, African Americans always have valued education. Historically Black colleges and universities (HBCUs) were established to educate Blacks. The racial integration of predominately White institutions (non-HBCUs) in the 1960s led to decreased enrollments in HBCUs and challenged their relevance. The purpose of this study is to discover what factors influence African American students to choose an HBCU today.

Quantitative, secondary survey data methods were used to conduct the study.

African American students at HBCUs and non-HBCUs participated in the survey. Consistent with generally accepted approaches in analyzing student college choice, this study utilized logistic regression to isolate the relationships between independent variables and dependent variables after controlling for other variables.

Influences affecting Black students’ college choice fell into three main categories: student characteristics, economic factors, and sociological factors. Students’ high school grade point averages were one primary predictor for selecting an HBCU. Other influences were found in students’ socioeconomic backgrounds. Policymakers, 
counselors, and teachers must understand that while financial aid is important, it is not always the greatest influence when African American students are choosing a college. It is important for those working with African American students to understand multiple factors in order to give optimal support in the decision process. 


\section{TABLE OF CONTENTS}

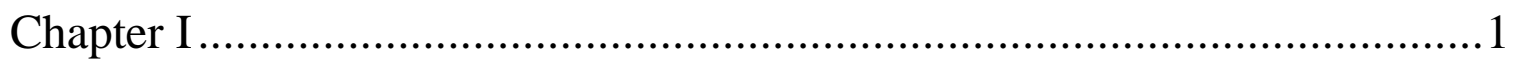

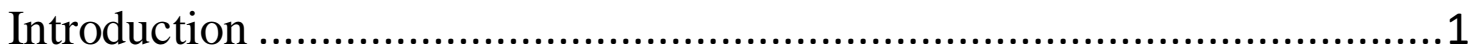

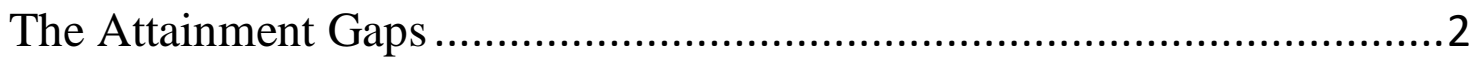

Benefits of Higher Education.................................................................

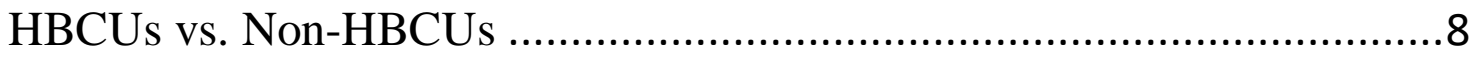

Conceptual Framework ..................................................................

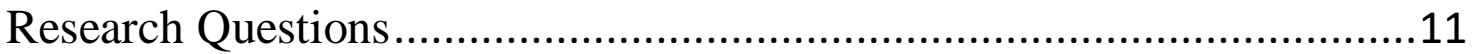

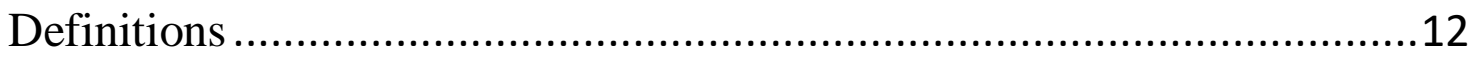

Summary of Chapter I..................................................................14

Organization of the Dissertation .......................................................14

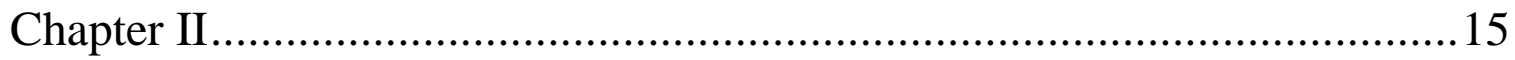

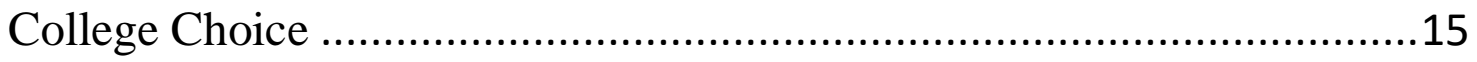

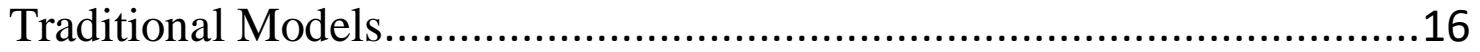

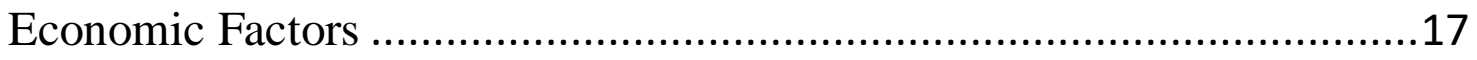

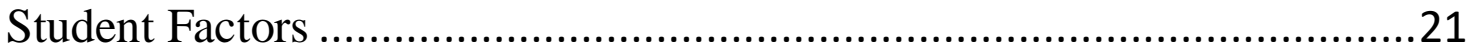

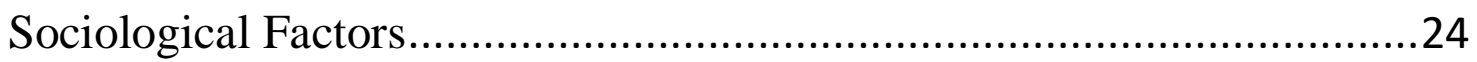

Historically Black Colleges and Universities (HBCUs) .........................27

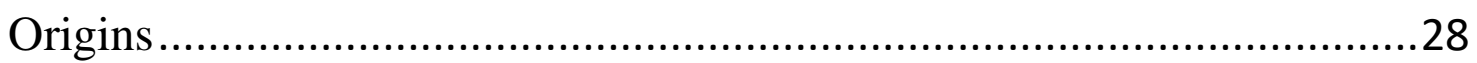

History Since School Desegregation .................................................32

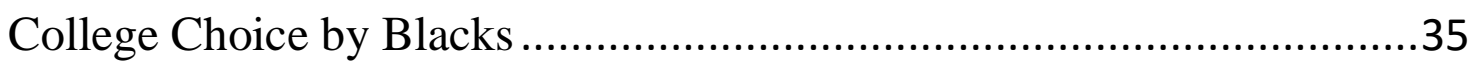

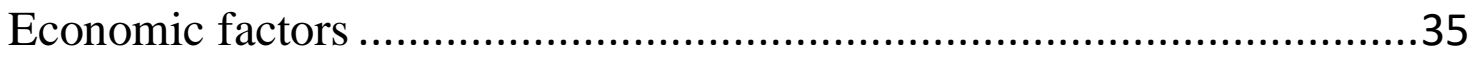

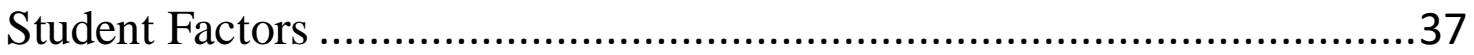

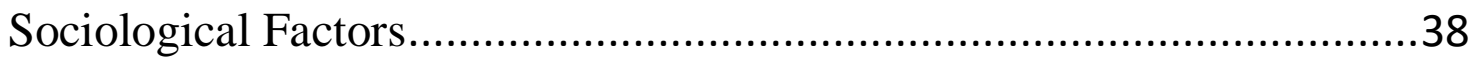

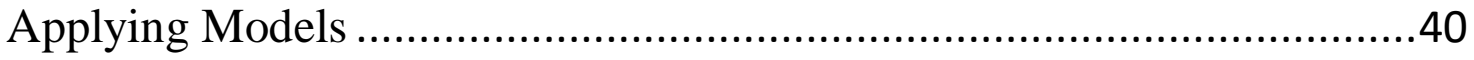

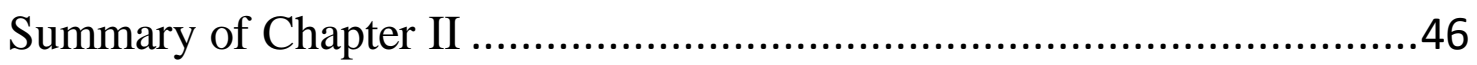

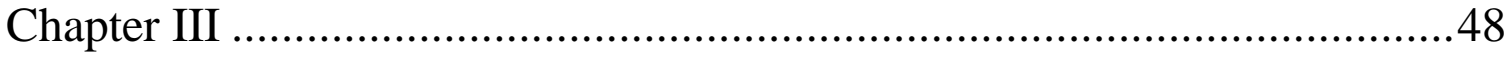

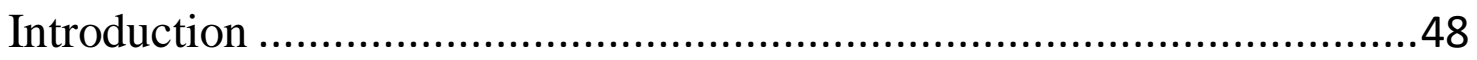




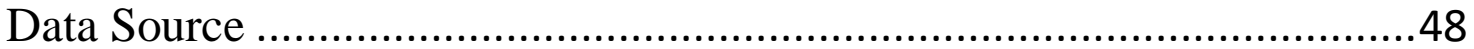

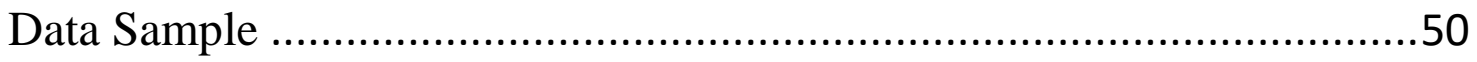

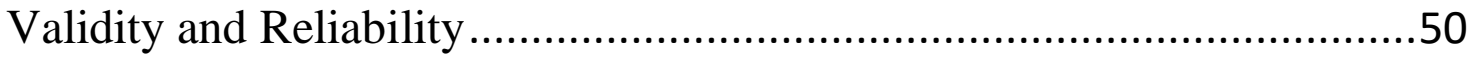

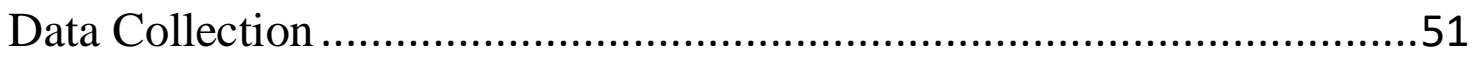

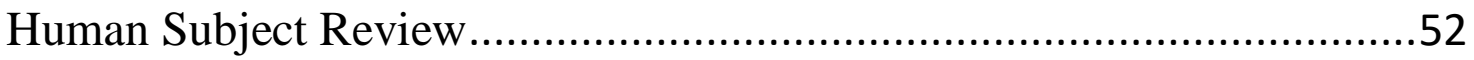

Research Questions and Model .........................................................52

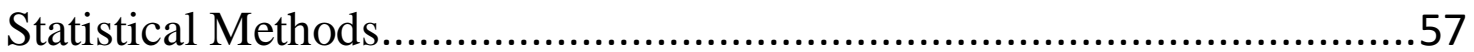

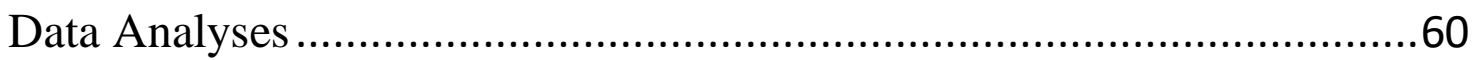

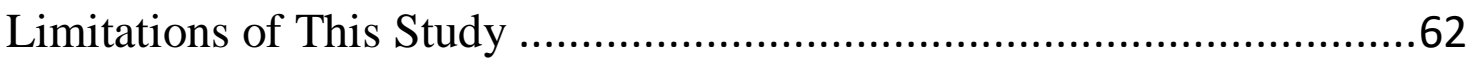

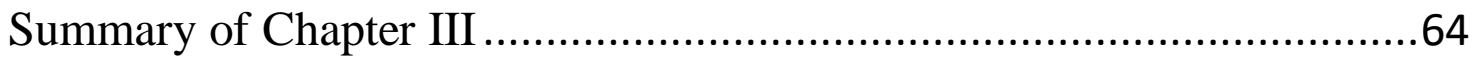

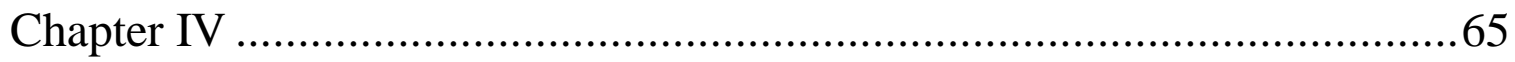

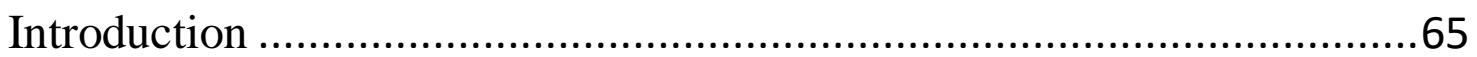

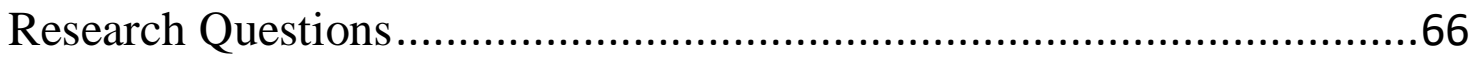

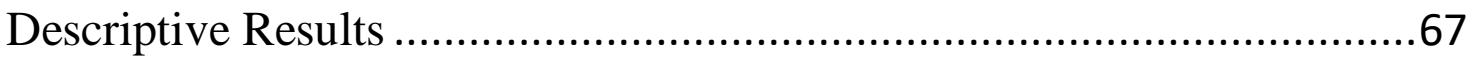

Logistic Regression Results .............................................................70

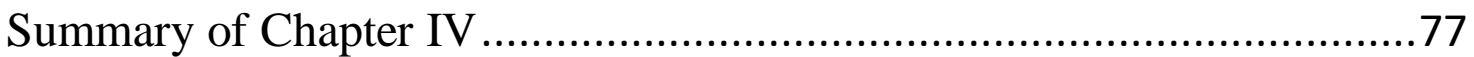

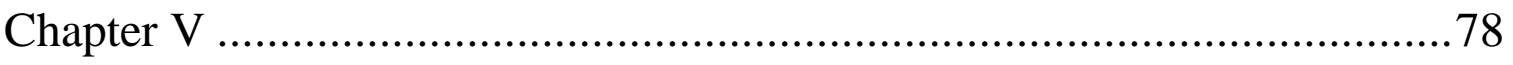

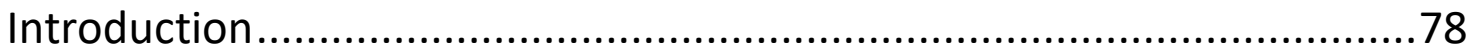

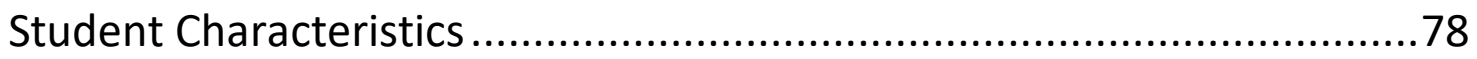

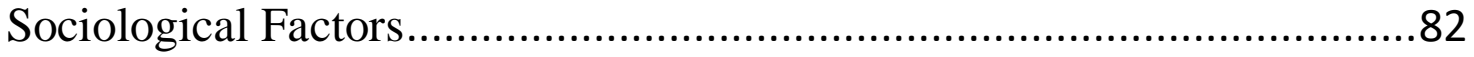

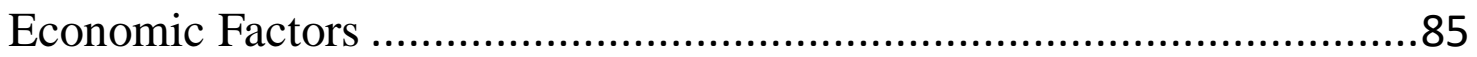

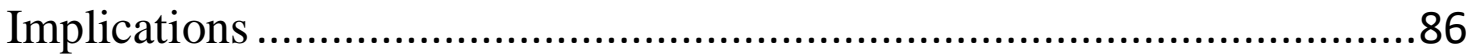

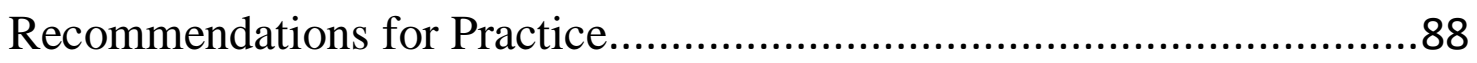

Recommendations for Research..................................................91

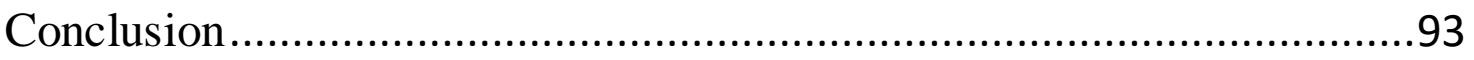

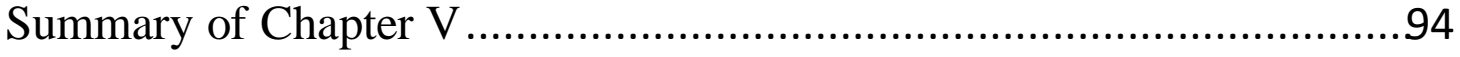

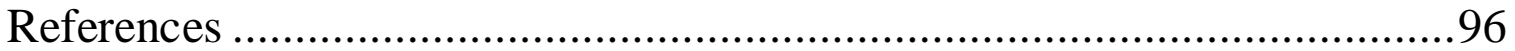

Appendix A: 2015 CIRP The Freshman Survey (TFS) ............................111 
Appendix B: List of 2015 TFS Participating Institutions.........................116 Curriculum Vitae .................................................122 


\section{CHAPTER I}

\section{Introduction}

Postsecondary education of Black Americans lags behind postsecondary education of White Americans (Duncan, 2013; Snyder et al., 2017; Strayhorn \& Terrell, 2010). According to the National Center for Education Statistics, in 2015 44.5\% of White Americans age 18-24 were enrolled in degree-granting postsecondary institutions, while the percentage for Black Americans was 36.1\%. (Snyder et al., 2017, Table 302.62). The same NCES report found that 55.9\% of White full-time bachelor's degree-seeking students at four-year postsecondary institutions graduated within five years of initial enrollment, while for Black students the percentage was 29.1\%. (Snyder et al., 2017, Table 326.10).

Enslavement of Blacks in the United States, followed by a century of denied access to schools of choice, gave rise to a post-secondary American educational landscape unique for Blacks. That history, which Chapter II will summarize, gave rise to a formal designation in the Higher Education Act of 1965 for historically Black colleges and universities (HBCUs). The Act defined an HBCU as “... any historically black college or university that was established prior to 1964, whose principal mission was, and is, the education of black Americans, and that is accredited by a nationally recognized accrediting agency or association determined by the Secretary [of Education] to be a reliable authority as to the quality of training offered or is, according to such an agency or association, making reasonable progress toward accreditation.” For today’s Black high school graduate choosing a four-year college, HBCUs stand as an educational option the student will consider as an alternative to non-HBCUs, often denominated PWIs 
(predominantly White institutions). This dissertation seeks to explore, understand, and explain the considerations that underlie a college-bound Black student's choice to enter either an HBCU or a non-HBCU. Both enrollment options offer advantages and include drawbacks, which this dissertation will explore.

Making the better choice - HBCU or non-HBCU - has the potential for optimizing the student's prospects for completing his or her degree and for accomplishments in later life. The value of postsecondary education only begins with college enrollment. Realizing full value requires persistence to graduation, followed by further learning, development, and achievement. This may involve postgraduate degrees and will culminate in a lifetime of productive and socially responsible adult conduct informed by education.

The current education disparity by race correlates to measures of personal wellbeing. For example, according to the U.S. Census Bureau, the median income in 2016 for White households was $\$ 65,041$, compared to a $\$ 39,490$ median income for Black households (Semega et al., 2017). This dissertation hopes to help guide high school counselors, parents, college recruiters, college admissions officers, and the college-bound students themselves toward the enrollment decisions most likely to yield productive postsecondary experiences, degree completions, and successful value-producing lives.

\section{The Attainment Gaps}

Colleges and universities in the U.S. are more racially, ethnically, and culturally diverse today than in the past, but significant gaps continue across racial and ethnic groups (Strayhorn, 2010). Gaps continue between minorities and Whites both for enrollments and for graduations. According to the U.S. Department of Education's 
National Center for Education Statistics (2017), 14.6 million students were enrolled in public and 5.4 million students were enrolled in private colleges in 2015 (Snyder et al., 2017, Table 301.10). The same study found that for recent high school graduates, $71.3 \%$ of Whites in 2015 were enrolled in two-year or four-year colleges, while the percentage for Blacks was 55.6\% (Table 302.20). The race disparity for postsecondary education widens after enrollment. For students enrolled in baccalaureate programs in 2011, NCES numbers showed that 59\% were White and $14.4 \%$ were Black (Snyder et al., 2017, Table 306.20). Graduation statistics four years later, in 2015 , showed that $66.5 \%$ of bachelor's degrees were awarded to Whites, and 10.6\% to Blacks (Snyder et al., 2017, Table 322.20).

A study by Strayhorn and Terrell (2010) found that when Blacks do move on from high school to postsecondary institutions, they tend to enroll more in two-year colleges, less selective four-year colleges, and minority serving colleges (HBCUs). Strayhorn and Terrell note, "In addition, two thirds of all Black men who start college do not graduate within six years after initial enrollment..., the lowest graduation rate among both sexes and all racial/ethnic groups” (p. 2).

Underlying the gap between Black and White educational attainment are disparities in family financial resources. About $82 \%$ of high school students from highincome families enroll in college, compared to $52 \%$ of graduates from low-income families (NCES, 2015), and household incomes, as noted above, have a partial reflection in race. Low family financial resources impact negatively on college readiness, college enrollment, and college completion. Owens (2017), writing about inequalities in elementary and secondary school preparation, notes that "income segregation between 
school districts creates inequality within economic and social resources available to advantaged and disadvantaged students. ... Considering both income and race jointly, high-income families live in affluent districts created by income segregation; black families live in districts more similar to low-income white families. Results indicated that spatial inequalities created by income segregation between school districts contribute to achievement gaps between the advantaged and disadvantaged students” (p. 1-27).

The National Center for Education Statistics, in its report on the 2015 Average National Assessment of Education Progress, documented racial gaps in math, reading, and science achievement among $12^{\text {th }}$ graders, as measured by standardized tests. Average math scores showed a 30-point gap between Whites (160) and Blacks (130). The gap in reading scores was almost as wide: Whites (295), Blacks (266). The gap in science scores was wider: Whites (160), Blacks (125). The average ACT score for White students was 22.3. For Blacks, 16.9. On average, Whites scored higher than Blacks in all areas of the SAT: 529 vs. 431 in reading, 534 vs.428 in math, and 513 vs. 418 in writing. White and Black grade point average data from NCES (2011) showed 3.09 for Whites and 2.69 for Blacks. The achievement gaps evidenced by these scores are only one indicator of college readiness, but the scores weigh heavily in college enrollment and college choice, and as a predictor for college success (Snyder, 2018).

In addition to its impact on the measures of academic achievement, income segregation in elementary and secondary years means that relatively fewer Blacks are schooled in settings where college aspirations are constantly encouraged and given support. Diminished motivation is further eroded by financial stresses, which, on average, are more acute for Blacks than for Whites. Reductions in college loan programs after the 
2008 recession raised the financial barriers even higher. Under 2011 adjustments to the Federal PLUS loan program, more families have had a harder time financing education, and more students have either had to forgo college enrollment or drop out before college completion (Carter, 2018; Miller 2017). U.S. economic recovery following the 2008 recession enabled some restoration of student aid. The 2019 FUTURE (Fostering Undergraduate Talent by Unlocking Resources for Education) Act allocated an additional \$25 million in funding for Federal Pell grants, awarded to undergraduate students who display exceptional financial need.

\section{Benefits of Higher Education}

Most students who acquire postsecondary education gain access to a wide range of personal, financial, and other lifetime benefits. The education disparity for Blacks denies these benefits, at a cost not only to the Black community but also to all Americans. Taxpayers and society as a whole benefit directly and indirectly when citizens have access to higher education. Some students have full access to higher education and some have partial access, especially when it comes to particular institutions. This partial access can depend on the individual's academic, financial, and parental socioeconomic status. For much of the last century, Americans have considered college education the primary vehicle enabling upward mobility. Recent data have shown a positive correlation between higher education and higher earning for all racial/ethnic groups. For instance, the National Center for Education Statistics (2016) reported that the median earnings with a bachelor's degree is $\$ 49,900$, significantly more than the $\$ 30,000$ earned by high school graduates, or the $\$ 25,000$ earned by those who did not complete high school. According to Ma, Pender, and Welch in Education Pays 2016, in 2015, 4\% of bachelor's degree 
recipients age 25 and older lived-in poverty, compared with 13\% of those whose highest degree was a high school diploma (p. 4).

The benefits of higher education are shared by individual students and their society. Higher earnings of educated workers generate higher tax payments at the local, state and federal levels. Ma et al. (2016) reported that four-year college graduates pay on average 91\% more in taxes each year than do high school graduates, and "Spending on social support programs such as unemployment compensation, the Supplemental Nutrition Assistance Program (SNAP), and Medicaid is much lower for individuals with higher levels of education” (p. 8).

On average, lifetime wage earnings for an individual with a bachelor's degree are \$1.1 million higher than for an individual with only a high school diploma (Carnevale, Smith, \& Strohl, 2010). Compounding the advantage in direct wage earnings, college graduates enjoy the more generous benefits that come with higher-paying jobs. According to Ma et al. (2016), "In 2015, 43\% of high school graduates working full time year-round in the private sector were offered a retirement plan, compared with 52\% of those whose highest degree was a bachelor’s degree” (p. 31). And among the latter group, 66\% received employer-provided health insurance coverage in 2015, compared to 54\% for those whose highest degree was the high school diploma (p. 32).

Beyond the benefits that derive directly from better jobs, college education confers or at least correlates to other qualities that serve both the college graduate and the community at large. Mayhew et al. in How College Affects Students, Volume 3 (2016) reported a 22-percentile point increase in moral reasoning scores over the span of four years spent in college enrollment (p. 355). Mayhew et al. also found a 17 or 18 percentile 
point average gain over four years of college in critical thinking skills, a measure of cognitive growth (p. 145). These improvements help explain several behavioral differences that distinguish college graduates from those whose education stopped with high school. Ma et al. (2016) reported that in 2014, cigarette smoking rates were $8 \%$ for four-year college graduates but $26 \%$ for high school graduates (p. 36). That same year, $62 \%$ of those holding at least a bachelor's degree but only $40 \%$ of high school graduates reported meeting or surpassing the federal guidelines for minimal weekly physical and aerobic activity (p. 37). Not coincidentally, Ma et al. reported that for the range of years 2011-2014, obesity rates for college graduates were 26\% lower for men and 40\% lower for women than the corresponding obesity rates for high school graduates.

A college education contributes to the public good in a variety of ways. Civic involvement, as measured by rates of volunteer activity, is much higher for college graduates. According to the Bureau of Labor Statistics study Volunteering in the United States 2015, 39\% of college graduates reported volunteering in 2015 , compared to $16 \%$ of high school graduates. Voting rates also correlate strongly to education level. According to the U.S. Census Bureau, in the 2012 Presidential election, 77\% of those with a bachelor's degree or higher voted, but only 38\% of those whose highest degree was a high school diploma.

The benefits of higher education are critical in the ever-changing economy and society. As the U.S. transforms from a manufacturing-based economy to an economy based on knowledge, college serves as the gateway to better options and more opportunity. Individuals who participate in higher education can expect to see financial 
returns along with personal and intellectual gains, and as these individuals benefit, so too does the society of which they are contributing members.

\section{HBCUs vs. Non-HBCUs}

High school graduates moving on to college typically seek the rewards that college completion tends to provide. However, by the statistical measures noted earlier, many Black Americans will enter college relatively lacking in important resources that correlate to college success. Against this backdrop of resource constraints, Black high school graduates entering a four-year college will choose either an HBCU or a nonHBCU. Many factors go into that decision (Eagan, 2015; Perna, 2000, 2006, 2007), and analysis and discussion of those factors constitute Chapters III and IV of this dissertation.

Pros and cons for the HBCU vs. non-HBCU decision cut across four constructs used widely in social science studies. The first of these constructs is the idea of human capital, the individual competencies, knowledge and personality attributes one possesses which enable one to perform labor to produce economic value (Garcia, 2014). Second is social capital, the supportive ties or relationships with individuals who share valuable resources and privileges that can promote advancement within society (Stanton-Salazar, 1997). Third is cultural capital, the acquisition of the tastes, preferences and norms that confer higher status and provide greater access in a class society (Bourdieu \& Passeron, 1977). Finally, there is financial capital, especially important for college choice due to rising costs and the decline in financial aid that combine to enlarge the net cost burden that low-income families face.

HBCUs have historically accumulated fewer financial resources than other colleges. Endowments and alumni giving are lower at HBCUs. By contrast, many non- 
HBCUs have created affordability programs in an effort to remove the financial barriers that in the past have prevented students from lower socioeconomic strata from attending college. Some of these programs began with elite institutions such as Stanford and Harvard, where administrators enabled students from families making less than a certain annual income to attend college free. Other schools are making a commitment that any student who qualifies for financial aid will graduate debt free. So, enrollment in a nonHBCU often becomes the more affordable choice for a student's initial financial outlay.

For Black college freshmen, however, first year enrollment translates to a fouryear degree at a rate significantly lower than the completion rate for Whites. In a 2012 paper published by the Frederick D. Patterson Research Institute, United Negro College Fund, Richards and Awokoya examined data from the National Center for Education Statistics’ Integrated Postsecondary Data System (IPEDS) for the 2008-2009 academic year. The authors concluded that for entering Black freshmen who were comparable in their financial resources and pre-college academic achievement, HBCUs graduate these students at a rate $14 \%$ higher than the rate for non-HBCUs. A newer NCES study, "Status and Trends in the Education of Racial and Ethnic Groups 2018," found that in 2016, although Black enrollment at HBCUs accounted for only 9 percent of overall Black enrollment in post-secondary institutions, HBCUs conferred 14 percent of all bachelor's degrees awarded to Blacks (de Brey et al., 2019).

Contributing to the favorable outcomes at HBCUs are some sociocultural positives for Blacks in the campus environment at HBCUs and corresponding negatives at non-HBCUs. Research has shown that HBCUs are more welcoming and supportive environments for Blacks than are non-HBCUs. "HBCUs tend to operate on a family 
model where faculty and staff act as surrogate parents to nurture and support their students, many of whom they perceive as their own kids” (Strayhorn \& Terrell, 2010, p. 2). Strayhorn and Terrell also found that Black students attending non-HBCUs often experience alienation and are not engaged on campus. Some Blacks attending private non-HBCUs complain of lack of access to student support services, express discontentment with their social experiences, and experience racism and hostility (Strayhorn \& Terrell, 2010). Solorzano, Ceja and Yosso (2000) found that Blacks attending elite non-HBCUs experience more racial microaggressions, which are defined as unconscious and subtle forms of racism.

With regard to attainments during and after college years, other indicators point to differences that reflect favorably on HBCUs. HBCUs enroll about $14 \%$ of all Black students (Bigg, 2009), but Dexter Mullins (2013), citing a study undertaken by former Massachusetts Institute of Technology chancellor Philip Clay, reports that HBCUs produce $18 \%$ of all Black engineers, $31 \%$ of Black scientists and mathematicians, and $42 \%$ of Black agricultural scientists. More than $70 \%$ of Black dentists and physicians received their degree from HBCUs.

\section{Conceptual Framework}

Two college choice models have helped to frame this study. First, Hossler and Gallagher's (1987) college choice model specifies three stages in the choice process: the predisposition phase (a student decides whether to attend or not to attend); the search phase (a student searches for information about college); and the choice phase (the student makes a choice). This study focuses on the third stage, the decision students make regarding which college to attend. The research examines Black students' background 
characteristics, especially the economic (financial resources) and sociological (i.e., cultural and social capital) factors. Second, Perna (2006) proposed a multilevel conceptual model. The model draws on multiple theoretical perspectives and situates the decision-making process within several layers of context: (1) habitus; (2) school and community; (3) higher education context, and (4) social, economic, and policy. This combined or integrated model draws on both economic and sociological perspectives and assumes that students' educational decisions are determined, at least in part, by their habitus, or the system of values and beliefs that shapes an individual's views and interpretations (Paulsen, 2001; Paulsen \& St. John, 2002; Perna, 2000; St. John, Asker, \& Hu, 2001; St. John et al., 2005). A key strength of the integrated conceptual model is the assumption that the pattern of educational attainment is not universal but may vary depending upon racial/ethnic and socioeconomic backgrounds (Paulsen \& St. John, 2002; St. John, Asker, \& Hu, 2001). This approach addresses the concern raised by some scholars that policy interventions will not effectively close gaps in student college choice without recognizing the culture and circumstances of a particular group (Freeman, 1997).

\section{Research Questions}

This dissertation focuses specifically on Black students and the factors influencing the choice they make to enroll either at an HBCU or at a non-HBCU. The study examines the following research questions:

1. To what extent do certain student background characteristics (e.g., gender, high school type, accepted in first choice, first generation, board scores, degree aspiration, institution control, high school grade) predict the choice to attend an HBCU for African American students, controlling for other key factors? 
2. To what extent do certain economic factors (e.g., parent income, financial concern, need-base grant education) predict the choice to attend an HBCU for African American students, controlling for key factors?

3. To what extent do certain sociological factors (e.g., parent influence, teacher influence, counselor influence, race composition in high school, race composition in neighborhood, parent education) predict the choice to attend an HBCU for African American students, controlling for other key factors?

\section{Definitions}

To assist with understanding the study, the following terms are defined.

African American or Black: a person having ancestral origins in any of the Black racial groups of Africa (Planty, Hussar, \& Snyder, 2009).

College choice: enrollment in 4-year HBCUs or non-HBCUs as of 2015.

Student aspirations: the wishes or desires expressing an individual's hopes about the future (Chapman, 1981).

Cultural capital: the system of factors such as knowledge, skills, and education that establish relative advantage and status in society. Parents provide their children with cultural capital by transmitting the attitudes and knowledge needed to succeed in the current education system (Bourdieu, 1986).

Economic factors: the model that posits that an individual makes decision about attending college by comparing the benefits with the cost for all possible alternatives and then selecting the alternatives with the greatest net benefits, given the individual's personal tastes and preferences (Hossler et al., 1989; Manski \& Wise, 1983). 
Habitus: the internalized systems of thoughts, beliefs, and perceptions acquired from the immediate environment, conditions and individuals' expectations, attitudes, and aspirations (Bourdieu \& Passerson, 1990; McDonough, 1997).

High school types: (a) public: a community or district that constitutes a system of free public education including primary and secondary schools.

(b) private: a school that is maintained by a private group rather than by the government, usually charging tuition and following a particular philosophy, viewpoint, etc.

(c) magnet: a public school with specialized courses or curricula.

(d) charter: a funded independent school established by teachers, parents or community groups with local or national authority.

(e) home school: one's student educated at home instead of sending him or her to school.

Historically Black colleges and university (HBCU): postsecondary institutions established prior to 1964, whose principal mission is the education of Black Americans (Planty et al., 2009).

Human capital: knowledge, talent, and skills possessed by individuals acquired through formal schooling and on-the-job-training (Paulsen, 2001, 1998).

Social Capital: inclusion in and maintenance of social networks, established by an individual's relationships with others and through organizational memberships (Perna, 2006).

Sociological factors: typically emphasize the way in which socioeconomic background characteristics influence student decisions (Terenzini, Cabrera, \& Bernal, 2001). 


\section{Summary of Chapter I}

A student's decision to attend college derives from many factors including race, gender, academic preparation, and college selection. Academic and financial limitations can be a particular problem for Black students. The purpose of this study is to provide additional research on Blacks and their decision to attend a particular type of four-year institution (HBCU or non-HBCU). College administrators, admission officers, and high school counselors can benefit from increased understanding of the factors that are associated with or that impact Black students' institutional choice.

\section{Organization of the Dissertation}

The first chapter introduces the study, purpose of the study, significance of the study, conceptual framework, and research questions. Chapter II examines the college choice models and sociological and economic perspectives that influence college choice. Chapter III describes the research methods used in the study, including sampling techniques, instrumentation, data collection, and analysis procedures. Chapter IV provides the results of the study. Chapter V discusses implications for future research. 


\section{CHAPTER II}

\section{College Choice}

The college choice literature spans more than 50 years of empirical research. The literature has provided theoretical frameworks and models of college choice that explain the process that students engage in, and the factors that influence students' decisions to enroll in institutions of higher education. Hossler, Braxton, and Coopersmith (1989) applied the term "college choice" to an individual's decision (a) to pursue or not pursue higher education, (b) to enroll in a 4-year institution or to enroll in one conferring a lesser degree or certificate, (c) to enroll in a selective institution, and (d) to choose a specific institution over other alternatives. In McDonough’s 1997 study, the term also encompasses the student's choice of public versus private institutions, more expensive versus less expensive institutions, first-choice versus lower-choice institutions, and the "right” college from a choice set. In studies of college choice, researchers have developed constructs applying various perspectives, particularly, economic, personal, and sociological. The current study, following the literature and applying similar perspectives, examines college choice in a specific context. This study restricts its focus to the choice made by African Americans to select either an HBCU or a non-HBCU for full-time enrollment in a four-year institution.

In this chapter, I examine the theoretical frameworks for college choice and the existing college choice models. Next, I provide some background information on HBCUs, the college alternative that Black Americans, especially, will consider as an 
option for their post-secondary education. Finally, I summarize research that recognizes how economic, personal, and sociological considerations in the process weigh differently for Black Americans as compared to White Americans engaged in college choice. Restricting my focus to Black Americans entering four-year college programs, I hope to create the context for which data collected on the HBCU vs. non-HBCU college choice decision will become meaningful.

\section{Traditional Models}

The most widely used college choice model identifies three general stages: predisposition, search, and choice (Hossler \& Gallagher, 1987). This model considers the sequence of factors that impact the decision-making process and the role of external resources. This is the most widely used college choice model, but other researchers also paved the way. Twenty years prior to the establishment of Hossler and Gallagher's model, sociologists (Sewell \& Shah, 1967) examined the influence of socioeconomic status and intelligence on enrollment and persistence in higher education. Chapman (1981) provided a general model of college choice that explored how the process differed or what was similar for various types of students. Recently, Garcia (2014) looked at college choice in the context of social mobility and family educational attainment. Students were examined by their family income, high school size, quality of the school, and resources that were available at the school. These models and frameworks, although not as widely used as Hossler and Gallagher's, have shown promise in helping to understand college choice with finer granularity. Chapman (1981) investigated the influence of family financial resources in assigning varying weights in the college choice process to tuition price, availability of financial aid, and campus location. Garcia (2014) 
explicitly acknowledged (p. 10) her dependence on the conceptual model presented in 2006 by Laura Perna, a model whose breadth and flexibility allow consideration of many factors (e.g., public policy, college recruitment practices, high school environment, etc.) in attempts to explain an individual's college choice. Collectively, the frameworks for analyzing college choice consider contributing factors that can be grouped into three general categories: economic, student, and sociological. I will use these groupings in the summaries that follow.

\section{Economic Factors}

Economic theory posits that individuals compare the costs and benefits of all possible alternatives and then select the one alternative with the greatest net benefit that meets the individuals' preferences (Hossler et al., 1989; Manski \& Wise, 1983). Garcia’s 2014 college choice study includes economic measures: family income, perceived importance of costs and financial aid, and expected living expenses. Economic theory aids in understanding the college choice process. This theoretical perspective helps focus discussions by comparing alternatives available to achieve the desired educational objectives (Klevorick, 1975).

The economic approach to college choice suggests that human capital (Becker, 1962) and supply-and-demand theory are the basis by which college enrollment decisions are made. As stated in Chapter I, human capital refers to an individual's competencies, knowledge, and personality attributes that enable him or her to perform labor that produces economic value (Becker, 1962; Garcia, 2014). Through education as well as through experience, an individual acquires these attributes. 
Human capital theory suggests that individuals decide to invest time, effort and money if they expect this investment will be rewarded by higher future earnings. Becker (1962) theorized that education is an investment in human capital. The individual would compare the cost and benefits, making the decision that best aligns with the individual's preferences (Hossler et al., 1989; Manski \& Wise, 1983). Human capital theorists suggest that a student's academic choices reflect individual differences in expectations, tastes, preferences, and degree of certainty regarding college enrollment decisions (DesJardins et al., 2006; Manski \& Wise, 1983).

Supply and demand theory provides a theoretical framework for understanding how a student decides which institution type to attend. According to this perspective, the demand for higher education is related inversely to price. Individuals weigh the costs and benefits of investing economic resources in addition to their ability to finance their education. The central tenet of the human capital model is the expected cost of attending college. The likelihood of enrolling in college and the type of college in which a student enrolls are related to tuition and cost (Avery \& Hoxby, 2004; Kane, 2010). Research shows that enrollment in colleges and universities declines when tuition increases (Heller, 1999; Kane, 2010, St. John et al., 2005).

Leslie and Brinkman (1987) reviewed 25 studies examining the connection between tuition and college enrollment by type and control and found that all students are sensitive to tuition costs. For example, it was estimated that every $\$ 100$ increase reduced enrollments between 1.8 and 2.4 percentage points. Heller (1997) reviewed 10 tuition enrollment studies and found a pattern consistent with Leslie and Brinkman. Heller concluded that every tuition increase of $\$ 100$ leads to a decline in enrollment from 0.5 to 
1.0 percentage points. Researchers typically include separate measures of tuition and financial aid, rather than the net price (Ellwood \& Kane, 2000; Heller, 1997).

Edward St. John and Michael Paulsen have published multiple studies examining the economic factors that contribute to college choice. Their joint 2005 study considered not only initial enrollments but also how tuition and other financial factors influence students' decisions to persist. They found that each additional thousand dollars of tuition decreased the probability of persistence by about 12\% (St. John et al., 2005).

The cost of education is continually rising in the United States, but assessing this trend requires a nuanced analysis. According to The College Board, for the 2018-19 academic year, the average published cost of tuition and fee prices for full-time in-state students in public four-year institutions ranged from $\$ 8,600$ at bachelor's institutions and $\$ 8,850$ at master's institutions to $\$ 11,120$ at public doctoral institutions. The average published tuition and fees price for full-time out-of-state students at public four-year institutions is as much as three times the price for in-state students. The average out-ofstate tuition and fees price increased from $\$ 25,670$ in 2017-18 to $\$ 26,290$ in 2018-19. The average published tuition and fees price for 2018-19 at private non-profit institutions was $\$ 35,830$ in $2018-19$, as much as four times the average published in-state price at public four-year institutions (Ma et al., 2018).

If trends in the cost of college are looked at not by published prices but instead by actual average net prices paid, with inflation considered, the picture changes dramatically. Writing for the Federal Reserve Bank of St. Louis in 2014, Scott A. Walla found that when the offsets of financial aid are considered, the cost of college in constant dollars remained essentially unchanged between 1978 and 2013 (Walla, 2014). Analysis 
by The College Board generally confirmed Walla's findings, although modest increases in average net dollar costs have appeared over the last five years (Ma et al., 2018). In constant dollars, after offsets, the average annual net tuition and fees paid by an in-state student at a public four-year institution rose from $\$ 3,390$ to $\$ 3,740$ between 2013-14 and 2018-19. At private institutions, the increase was from $\$ 13,380$ to $\$ 14,610$. The tighter pinch experienced by today's families faced with financing college is real, but it derives largely from the failure of average incomes to keep pace with inflation.

With tuition costs reaching and sometimes exceeding median family incomes, families are concerned regarding affordability. For many students, the direct cost of attendance is reduced by financial aid. The influence of financial aid is one of the most widely researched in the college choice process, primarily because of its implications for institutional, state, and federal policy (Chapman, 1981). The central goal of financial aid is to provide equal educational opportunities to students regardless of financial ability. Financial aid promotes educational opportunities in terms of access and college choice (Kim, 2004). Equal opportunity of college choice must be achieved by offering financial aid to help with the cost of attending a particular institution. Braxton (1990) found a positive relationship between financial aid and selection of a particular college or university. According to Braxton, receipt of financial aid increases the chances that an accepted applicant will enroll by 8.5\%. In August 2006, American Behavioral Scientist devoted an entire number to student financial aid and public policy. In their contribution to that number, Amaury Nora and colleagues at the University of Houston observed that financial aid has positive effects for retention beyond the dollars it provides. Financial aid gives students the freedom to more fully engage in academics and in college 
extracurricular activities, and these engagements correlate strongly with college persistence.

Although economic theories are useful in helping one to understand the student college choice process, they cannot in isolation explain how financial decisions are made. Perna cites DesJardins and Toutkoushian (2005) in noting that different individuals, given the same quantifications of benefits and costs, will assess them differently due to different tolerances for risk (Perna, 2006). Again, citing DesJardins and Toutkoushian, Perna also notes that information about costs and benefits is not always equally available to all individuals (Perna, 2006, p. 108). Such limitations in financial modeling have given impetus to studies of college choice that explore more than just cost-benefit considerations. As noted by Garcia (2014), an individual’s decision to enroll in a particular institution can be influenced by non-financial factors, particularly those that are personal to the student herself or himself, or are sociological (Garcia, 2014).

\section{Student Factors}

Academic preparation correlates with college enrollment and persistence (Adelman, 1999). Research suggests that the higher a student's level of academic preparation, the greater the likelihood that the student will enroll in a four-year rather than a two-year institution. Studies show that the student's academic ability, as reflected in standardized test scores, and achievement (i.e., grade point average) have a great effect on a student’s decision to enroll in college (Hossler \& Gallager, 1987). Admissions to four-year colleges and universities are based on student grade point average, scores on standardized college entrance exams, and level of academic coursework. Researchers indicate that the single most important predictor of college enrollment is academic 
preparation (Cabrera \& La Nasa, 2001; Ellwood \& Kane, 2000; Perna, 2000, 2006). In her 2006 review of academic preparation, Perna found that the quality of the high school curriculum is the most important predictor of college enrollment. Research has shown that individuals with greater achievement are more likely to attain higher levels of education by either enrolling in a four-year college or university or enrolling in a highcost institution (Ellwood \& Kane, 2000; Hearn, 1988; Perna, 2000, 2006).

Academic achievement in some studies is measured by test scores (Ellwood \& Kane, 2000; Perna, 2000, 2006; Perna \& Titus, 2004, 2005) and by high school grades (Ellwood \& Kane, 2000; Hossler et al., 1998; Hossler \& Stage, 1992; Perna, 2006). Adelman (1999) stated that the highest level of coursework completed is a better indicator of academic preparation. Perna and Titus (2004, 2005) measured the quality of academic preparation by the highest level of mathematics coursework. St. John (2003) measured academic preparation by using the College Qualification Index. In his study, he divided students into three groups based on their qualification score: not college qualified, minimally/somewhat college qualified, and highly/very highly qualified. His descriptive findings showed that only $53 \%$ of low-income students were college qualified, compared to $68 \%$ of middle-income and $86 \%$ of high-income students. Additionally, 52\% of the low-income students who qualified for college enrolled in a four-year college, compared to 83\% of high-income students. St. John noted (p. 160) that "larger percentages of African Americans and Hispanics than Whites are from families with low incomes,” and thus, predictably, a smaller percentage of Black and Hispanic students were college-ready upon reaching the end of their secondary schooling, and college-ready Blacks and Hispanics were less likely to enroll in a four-year college. The 
correlations for readiness and enrollments, St. John concluded, were with family income, not with race or ethnicity.

Researchers have found gender patterns in the college choice decision. Perna and Titus (2005) reported that women are more likely than men to enroll in four-year institutions after high school graduation. The Johnson, Stewart, \& Eberly (1991) study on college choice revealed that men rated extracurricular activities, athletics programs, and friends as more important in choosing a college than did women; women rated academic reputation, quality of available programs, friendliness of the university/college, campus beauty, and proximity to home and family as more important than did men. Valadez (1998) examined the race, class, and gender differences of students who applied to college. The results revealed that on average, females applying to college could draw on greater educational and parental resources than could males. Jacob (2002) explored gender gaps in college enrollment and found that men were more likely to enroll in selective institutions when scores were high on standardized tests.

Psychological considerations also influence enrollment and college choice decisions. Tolerance for risk is a psychological factor in a student's college decisions. Like the student attribute of academic college readiness, tolerance for financial risk has correlations to family income. When family resources, scholarships, grants, and part-time wages do not combine to cover college costs, loans become necessary. Some students confidently expect future income will generate the money needed to pay off those loans. Less confident students will postpone or forgo college, or they will enroll while simultaneously taking jobs with so many work hours that full-time course loads become 
unsustainable. In order to better understand the factors that influence tolerance for risk, one needs to turn to sociological theory (Garcia, 2014).

\section{Sociological Factors}

Sociological factors typically emphasize the ways in which parental education and family/school influences impact student decisions to enroll in higher education (Perna, 2006). Sociological approaches evolve from the traditional status attainment models in the 1970s and 1980s that emphasized the constructs of cultural and social capital (Perna, 2006).

As stated in Chapter I, parents provide their children with cultural capital by transmitting the attitudes and knowledge needed to succeed in the current education system (Bourdieu, 1986). The educational background of parents has been shown to have a significant impact on an individual's decision to participate in higher education and to choose a particular institution. Students with parents who have received a bachelor's degree or advanced degrees are more likely to attend an institution of higher education, while students whose parents do not have any postsecondary education are less likely to enroll in a college or university (Cabrera \& LaNasa, 2001). Hossler and Stage (1992) found that the parents' education level was positively related to high expectations of the students, high grade point average, and student involvement in extracurricular activities. Research found that those students whose parents have college education are more likely to begin the college selection process earlier than those students whose parents have no college education (Shankle, 2009).

Using the same data regarding access to higher education institutions by students from different parental educational levels, Astin and Oseguera (2004) reported that 
students from highly educated parents outnumbered first-generation students seven to one (62\% vs. 9\%). Students whose parents' education falls in the middle level previously made up half the entering freshmen classes at highly selective institutions, but these students now are outnumbered two to one by students with highly educated parents (Astin \& Oseguera, 2004).

In selecting a college, students are strongly persuaded by comments from their family, peers and friends. In an early study, Johnson and Chapman (1979) reported that family and friends influence students in three ways. Family and friends can shape a student's expectations of what a particular college is like, and they frequently advise a student directly regarding which college to choose or reject. Finally, the student may lean toward a particular college because family members or friends have previously enrolled or are enrolling there. In Chapman’s 1981 study, first-year college students reported that friends' college choices influenced their own decision. The high school students in Chapman's study named their parents as having had an especially strong impact on their college choice. High school seniors were asked to name the most helpful person they consulted regarding choice of college. Students indicated the following: parents (43\%), high school counselors (22\%), friends (16\%); teachers (10\%), and college admission officers (9\%).

In a later study by Bradshaw, Espinoza and Hausman (2001), 82\% of college bound students reported that parents had influenced their college choice. In this group of students, 36\% stated that parental influence was highly significant. Ceja’s (2006) findings also found that parents play a vital role in shaping their children's initial feelings and aspirations regarding college. Perna and Titus (2005) studied the influence of friends. 
They found that when friends decide to attend a four-year college in the fall after graduation., a student is more likely to make the same decision.

Sociological theorists also assert that culturally valued tastes and the consumption patterns one inherits will dictate educational outcomes. Many abstract as well as concrete proxies for cultural capital include inherited items, art, education, and language. Other cultural capital theorists believe that consumption patterns reflect shared high status cultural signals (such as attitude, preferences, formal knowledge, behaviors, goods and credentials) which are used for social and cultural exclusions or rejections (Bourdieu \& Passeron, 1990).

Social capital, as stated in Chapter I, consists of the social networks that an individual establishes and maintains with other individuals and with institutions. Beyond family and friends, two types of networks have an impact on college choice. The first is the student's secondary school, especially his or her teachers and counselors. The second, whose relative influence has trended upward dramatically in the past decade, are the Internet-based social media in which the student participates (Garcia, 2014). Students access information regarding higher education via networks. A student's ability to draw upon these information resources plays an important role in the college choice process.

High school students in urban public schools can use the Internet as effectively as do other students, but on average they lack access to other sources of cultural and social capital that promote college enrollment. Tierney and Venegas (2006) found that this deficit may be reduced with creative programming by school administrators. When a group persists and works toward goals that are obtainable only because members rely on one another, this emulates a family dynamic and constitutes what sociologists call a 
fictive kinship. In a high school setting, students can bond into a fictive kinship whose goals center on preparing for a college future. Tierney and Venegas reported on nine lowincome high schools where fictive kinships with a college focus were formed and maintained by peer counseling programs. These programs enlisted the most motivated senior students to incubate, shape, and guide the fictive kinships. Participants, according to Tierney and Venegas, "see themselves, as college ready. Rather than ask questions such as 'Should I go to college?' or 'Am I qualified to go to college?' these students ask 'Where will I go to college and what do I need to get there?’” (p. 169)

Whatever the merits of existing literature that explores the underlying economic, student, and sociological factors that influence college choice, no generic analysis can satisfactorily explain the decisions made by Black students. Kassie Freeman made this observation in “The Race Factor in African Americans' College Choice” (1999b), in which she wrote, “...the college choice process for African American high school students is a complicated one that necessarily has to take into consideration the context of their culture" (p. 8).

\section{Historically Black Colleges and Universities (HBCUs)}

Few researchers have focused on the unique college choice process specific to Black American students. The two most cited studies are those produced by Freeman (2005) and by Strayhorn and Terrell (2010). In Freeman's book “African American and College Choice: The Influence of Family and School,” she focused on three areas: (1) who and what influence the type of higher education institution African American students consider; (2) the role of cultural affinity in the decision process of those considering HBCUs over non-HBCUs; and (3) why students from certain high school 
types tend to prefer a certain type of higher education institution over another. In Strayhorn and Terrell’s book “The Evolving Challenges of Black College Students: New Insights for Practice and Research”, the authors focused on the challenges Black students face in higher education across various types of institutions, considering both HBCUs and non-HBCUs.

\section{Origins}

To understand college choice for Blacks or African Americans today, we must consider the historical context in which many Blacks had few or no choices for schooling. Prior to the Civil War, slavery and segregation restricted educational opportunities for African Americans, with especially severe prohibitions in the South. From 1830 to 1860, four states - Georgia, North and South Carolina, and Virginia - had laws "making it illegal to teach slaves to read and write...." (Mintz, 2004, p. 108). James D. Anderson's The Education of Blacks in the South, 1860-1935 (1988), documented the determination and perseverance of Southern Black parents to overcome the legislative and institutional obstacles that prevented formal schooling for Black children. V.P. Franklin, in Cultural Capital and Black Education (2000), wrote that education was "seen as important for the advances of African Americans collectively in the United States, and thus the members of the community were willing to provide various types of support to ensure their schools’ success” (p. xv).

At the post-secondary level, abolitionists, some missionaries, and progressive White citizens joined Blacks to fight discrimination (Brown II \& Ricard, 2007). What began as churches and schools indoctrinating and educating slaves would later become the institutions now designated historically Black colleges and universities (HBCUs). 
The early HBCUs emerged from schools and training institutions that were founded by the missionaries and funded by philanthropists (Brown \& Freeman, 2004). Three institutions are often referred to as the nation's first HBCUs: Cheyney State and Lincoln Universities in Pennsylvania, and Wilberforce University in Ohio. Cheyney State, founded as The Institute for Colored Youth in 1837, began offering college level courses in 1900, while Lincoln opened in 1866 and Wilberforce opened in 1866 and is the oldest Black-controlled HBCU in the nation (Brown \& Ricard, 2007). Rather than requiring proof of high school completion, HBCUs opened their doors to all who sought to further their education. The first schools opened during the Civil War to educate African Americans and others who felt that their freedom would not be complete until they learned to read and write. HBCUs practically invented the open door policy that encouraged all to apply. Hedgepeth Jr, et al. (1978) wrote that:

The heterogeneous student body of the Black college gives them unique status among institutions of higher education. The policy of open admission goes beyond the acceptance of students with varying preparation for college work. It includes the acceptance of African, Asian, Caribbean, European, Latin, and White American students (p. 97).

The first Morrill Act of 1862 provided federal financial support for state education, especially in the disciplines of agriculture, education, and military science. The $13^{\text {th }}$ and $14^{\text {th }}$ Amendments to the U.S. Constitution, ratified later in the 1860 s, required states to provide public education to all former slaves and other Black Americans. These events in the aftermath of the Civil War led to a proliferation of HBCUs, with more than 200 founded prior to 1890. 
Passage of the second Morrill Act in 1890 mandated that spending of federal education funds must extend to institutions that enrolled African Americans. Thereafter, in place of the philanthropists and private interests, state governments became the main financiers of new HBCUs. Segregation would persist in the South into the 1950s, and in the intervening decades, many Southern states established public HBCUs for the sole purpose of ensuring state access to federal funds. The Higher Education Act of 1965, later amended, formally recognized and categorized as Historically Black Colleges and Universities (HBCUs) those degree-granting institutions founded prior to 1964 whose primary mission was, and continued to be, to educate Black Americans (Roebuck \& Murty, 1993).

Walters (1991) identified six specific goals particular to HBCUs: (1) maintaining the Black historical and cultural tradition; (2) providing leadership for Black community through the important social role of college administrators, scholars, and students; (3) providing an economic center in the Black community; (4) encouraging Black role models; (5) providing college graduates with a unique competence to address issues and concerns across minority and majority populations; and (6) producing Black graduates for specialized research, institutional training, and information dissemination for Black and other minority communities.

HBCUs have differed from most colleges and universities in at least two ways. First, they have a history of offering access to enrollees who may not have acquired the secondary school credentials that typically certify readiness for college. Second, they provide their students with course options that are praised by some as culturally, socially, economically, and politically relevant and disparaged by others as academically deficient. 
Writing for the Journal of Higher Education in 2006, Marybeth Gasman reviewed Black responses to a widely circulated Harvard Educational Review article (Jencks \& Riesman, 1967) that had characterized HBCUs as "academic disaster areas.” One of four responses, published in a subsequent number of the Harvard Educational Review, came from Dillard University President Albert W. Dent, who wrote, "If the condemnation by the authors serves to remind Americans that these colleges are, and always have been, in the forefront of discovering and developing otherwise wasted potential talents among disadvantaged youth, it may after all serve a worthwhile end” (Gasman, 2006, p. 331).

Disagreements regarding the merits and mission of HBCUs rose to public attention early in the twentieth century, when W.E.B. Du Bois challenged the views of Booker T. Washington. Washington believed that the HBCUs' primary function was to provide vocational training for the masses in conjunction with liberal learning (Brown \& Freeman, 2002). Du Bois believed that they should prepare an elite group of scholars capable of leading the broader African American population: "The Talented Tenth” (Browning \& Williams, 1978). Over time, HBCUs have largely steered a middle road, seeking to merge these two ideals into a mission of academics coupled with practical applications. Charles Willies (1981) wrote, “The synthesis of liberal arts and vocationally oriented courses in the curriculum of Black colleges and universities...has placed [HBCUs] in the vanguard of higher education” (p. 74).

Due to the large number of African American World War I veterans who were interested in higher education opportunities, by 1927 there were seventy-seven HBCUs, with an enrollment of about fourteen thousand students (Redd, 1998). Additionally, despite the economic depression in the 1930s, enrollment at these institutions grew by 
66\% from 1929-1940. By the end of World War II, African American veterans accounted for approximately one third of the enrollment at HBCUs. At that time, several philanthropic organizations such as the United Negro College Fund helped enroll African American students in HBCUs. Federal and state governments continued to provide funding for HBCUs. In the early 1960s, about 70\% of all African American college students were enrolled in HBCUs (Williams, 1993).

\section{History Since School Desegregation}

The 1950s and 1960s brought new challenges to HBCUs. First came the Supreme Court's 1954/55 desegregation decision in Brown v. Board of Education, and it was followed a decade later by passage of the Civil Rights Act of 1964. In 1965, President Lyndon Johnson signed Executive Order 11246, Affirmative Action, which required federal contractors to increase the number of minority employees as an "affirmative step" toward remedying years of exclusion for minority workers in those firms” (Harper et al., 2009, p. 397). The order also included public colleges and universities. As a result,

greater numbers of African Americans gained enrollment in non-HBCUs (Duncan, 2013).

Previously segregated non-HBCUs in the South now started admitting Blacks. Passage of the Higher Education Act of 1965 provided funds for low-income students of all races to attend postsecondary education institutions. This legislation further increased the number of African Americans enrolling at non-HBCUs. At the same time, the number of African American students at HBCUs began to decline.

Williams (1993) indicated that by 1968 only 36\% of all Black college students were enrolled in HBCUs, and by 1976 the number was only 20.1\%. Hauptman and Smith (1994) attributed the enrollment decline primarily to two factors: Black access to non- 
HBCUs made possible by changes in public policy, and increased Black enrollments in the newly created and expanding two-year community colleges. Bigg (2009) reported that HBCUs were enrolling about 14\% of all African American students. In 2016, the number had dropped to 9\% (de Brey et al., 2019).

The decline in enrollments has meant loss revenues, and some HBCUs have closed or merged with other institutions, while other struggle to exist. Since 2000, three HBCUs have closed: Mary Holmes College in Mississippi, Lewis College of Business in Michigan, and St. Paul's College in Virginia. According to a January 2019 report in the Atlanta Journal-Constitution, Atlanta’s Morris Brown College, with only 55 students enrolled, and several other HBCUs persist in name only, having been stripped of their accreditation and access to federal student loan programs. In 2015, the responsible accrediting agency put Pennsylvania’s Cheyney State, considered by many to be the nation's first HBCU, on probation. In November 2018, the agency extended Cheyney’s probation, pending further review in August 2019. If the probation is not lifted, Cheyney expects to close. Some HBCUs have shifted their student population from predominately Black students to predominately White students. This change was made by West Virginia State College, Lincoln University of Missouri, and Bluefield State College (Sink, 1995).

In 2014, The New York Times profiled Howard University, which had produced Supreme Court Justice Thurgood Marshall. Howard's other graduates include former United Nations Ambassador Andrew Young and current U.S. Vice President Kamala Harris. The article revealed that with the decline in enrollments, Howard had lowered its admissions SAT score requirements in order to widen the pool of applicants. In recent years, many private HBCUs have sharply increased their calls for alumni giving, not to 
build endowments but to meet operating expenses (Gaynor, 2014). For public HBCUs, questions about relevance have emerged more frequently as states face tough choices concerning financial aid spending and how to distribute increasingly limited education funds. Non-supporters of HBCUs have questioned the quality of education they provide. In its 2018 rankings of American colleges and universities, U.S. News and World Report ranked Spelman College first among HBCUs. In the ranking of all liberal arts collegesHBCUs and non-HBCUs—Spelman's rank was a tie for sixty-first.

Today, there remain about 100 historically Black colleges and universities across the U.S., continuing the mission of cultural growth and educational achievement for African American students. These institutions include 40 four-year public colleges and universities; 10 two-year public colleges; 49 four-year private, nonprofit colleges and universities; and 4 two-year private, nonprofit colleges. Many of these institutions are very small; some of these institutions enroll fewer than 1,000 students. HBCU enrollments in 2013 numbered 241,476 students, 175,287 in public HBCUs and 66,189 in private HBCUs.

According to trend data made available by the National Center for Educational Statistics (NCES, 2019) the total count of HBCU first-year enrollments has remained fairly stable in the years since 2013. However, the percentage of Blacks among enrollees continues to decline. In 2016, the last year reported in NCES's 2019 study, non-Black enrollee percentages across all HBCUs had climbed to 23 percent (de Brey et al., 2019).

In 2020, Mackenzie Scott, former wife of Amazon founder and multi-billionaire Jeff Bezos, donated \$40 million to Howard University and tens of millions of dollars to five other HBCUs (Brantley-Jones, 2020). However, many HBCUs are struggling 
financially, which limits their ability to offer financial aid. Dewan (2009) reported that Clark Atlanta University, Tennessee State University, and Spelman were forced to cut faculty, staff, and programs, to consolidate classes, and to reduce operating budgets. Despite the decline in enrollments at many HBCUs, Dewan (2009) found that these institutions continue to provide an environment that enables African American students to persist and graduate at a higher rate than their graduation rate at non-HBCUs.

\section{College Choice by Blacks}

The general college choice models (Hossler \& Gallagher, 1987; Hossler \& Stage, 1992) did not consider race and culture, but research on college choice has included some studies that focus directly on Black high school graduates and their specific considerations in choosing a college (Freeman, 1997, 1999a, 2005; Freeman \& Thomas, 2002; Gasman et al., 2007; McDonough, 2004; Perna, 2000, 2006; Strayhorn \& Terrell, 2010). There is still much to learn about how college-bound Black students make their choice.

\section{Economic factors}

Researchers have found that college cost is the primary concern for most African Americans students, more so than for White students (St. John et al., 2005). According to Heller (1997), Blacks are more sensitive than Whites to changes in tuition and financial aid, even after controlling for socioeconomic status and academic ability. In Freeman's (2005) qualitative study, African American students cited perceived economic expectations as a key influence on their choice to attend or not to attend college. "The responses reflect that African Americans have a fear not having enough money to attend college or of not getting a job that pays commensurate with the level of education after 
completing college “(p. 43). Students in Freeman’s 2005 study were more interested in making money and bettering their position in society than in positioning themselves in a specific business, career, or occupation. They were most concerned about the expected cost of a college education and future earning potential. When students considered higher education, especially those who anticipated possible labor market limitations, the question was, “Will college make a difference financially?” (p. 47)

As noted in the discussion of HBCUs, and also in Chapter I, non-HBCUs are frequently more able, at least for the first year of college, to make stronger offers of financial aid. Students from minority racial/ethnic groups respond differently to financial aid than do White students, according to Kim (2004). In part, the difference may derive from the correlations of race to income level. Perna (2005) found that students from lower family income levels are less likely to take out loans than are their higher-income counterparts. When aid was in the form of loans, not grants, Kim found that when more aid was offered, enrollment rates for African American students declined relative to the rates for Whites and Asians (Kim et al., 2009). Prospects for loan repayment factor into the thinking of lower-income college applicants, who, according to Heller (1997), are more conscious in their decision making than are upper-income students.

Freeman (1999b), while researching how economic expectations affect the college choice of African American students, found that expected cost and future earnings were assessed in the context of perceived job ceilings. The students in her study thought about going to college, but when they considered the job outlook, they saw how obtaining a college degree did not always translate into having a higher-level job. Duncan (2013) confirmed this finding. Students also complained to Freeman about receiving less 
favorable job treatment because of their race. Freeman (1999b) stated that "the combination of African American students' perception of job market limitations plus more or less equitable job treatment creates an insurmountable barrier in the minds of students considering whether or not to invest in higher education” (p.11).

Just as average family income levels in the United States correlate with race, so, too, do levels of cultural capital. Inherited from prior generations, cultural capital, as stated in Chapter I, confers status and secures access in a class society (Bourdieu \& Passeron, 1977). Students with higher levels of cultural capital likely enter the workforce into better paying jobs on career tracks that lead to advancements and promotions (Garcia, 2014). Students with lower levels of cultural capital are more likely placed in working class or lower-class jobs.

\section{Student Factors}

Comparing American Black high school graduates to White high school graduates, Chapter I summarized the gaps in academic readiness for college. On average, the Black graduates have accumulated less of the human capital that supports college admission and college success. Although African American students aspire to attend college, some may not have had exposure to various higher educational resources early enough to gain better understanding of academic requirements (Duncan 2013). Pitre (2006) compared the aspirations for and the perceptions of college enrollment as experienced by Black and by White students. Pitre found that African American students were just as likely to aspire to college as their White peers but had significantly lower academic achievement. The lower level of achievement resulted in part from African American students not being aware of college admissions requirements during their early 
high school years (Pitre, 2006). Pelavin and Kane (1990) reported that students who had enrolled in algebra, geometry, and science lab, and who had completed at least two years studying a foreign language, were more likely to enroll in college. These researchers' data showed that $40 \%$ of White students took geometry as compared to $19 \%$ for Blacks.

Beyond academic preparation, self-efficacy considerations distinguish Blacks from Whites on the question of college choice. Here again, correlations of race to income come into play. Hearn (1991) found that lower-income college-bound students are likely to choose institutions of lower selectivity, even when academic ability and other factors are controlled.

Freeman’s 2005 study identified students from certain high school types and related these types to the choice between HBCU and non-HBCU. Several themes emerged in the study. First, students who attended predominantly White private schools considered HBCUs for college because they wanted to connect with the African American community or their roots. They struggled with living a double life based on expectations of African Americans “acting White” at school (Duncan, 2013). Conversely, students who attended public high schools with diverse student enrollment or predominantly African American enrollment leaned toward attending non-HBCUs (Freeman, 2005). These students commented that attending a non-HBCU was more reflective of "the real world," since the world is not all Black.

\section{Sociological Factors}

In 1997, Salazaar developed a social capital framework for understanding the socialization of racial minority youth in the status attainment process. In this framework, the researcher described the hardships minority students might encounter in acquiring 
social capital. Garcia (2014) found that the two types of social networks with the greatest impact in terms of transmitting information to students are teachers or counselors from the school environment and the family or community members. Students access information regarding higher education via networks. A student's ability to draw upon networks plays an important factor in the college choice process. Although fictive kinships and the peer counseling programs described in the previously referenced 2006 study of select urban high schools may to some extent offset deficits in family-based social and cultural capital, that study's authors, Tierney and Vanegas, concluded that these are "a minor antidote to a severe problem" (p. 169).

School type appears as a personal factor when viewed from the perspective of a student's conscious reflections and evaluations in his or her choice of a college. It can be seen as a sociological factor in the degree to which it conditions the student unconsciously. Students who do not have the social capital necessary to begin their college search early may look to their high school guidance counselor for information on different colleges and universities. Freeman (2005) and also McDonough et al. (1997) found that school officials were more influential in encouraging African American students to attend non-HBCUs rather than HBCUs.

By contrast, the influence exerted by parents may tend to push Black students more often toward choosing an HBCU. For the totality of college-bound students, not considering race, Hossler and Gallagher (1997) found a decrease in parental involvement after the predisposition phase of the college choice process. Parental influence became secondary to peer and institutional influences once students moved into the search and choice phases. Smith and Fleming’s (2006) study found that for most Black students, 
parents remain quite active in all three phases of the student's college choice process. If the student had a family member who had attended or supported a particular college or university, this influenced the institution or type of institution the student considered for postsecondary studies (Freeman, 2005). HBCU alumni were seen to have especially strong ties to their alma maters.

\section{Applying Models}

Hossler et al. (1989) defined college choice as a "complex multistage process during which an individual develops aspirations to continue formal education beyond high school, followed later by a decision to attend a specific college, university or institution of advanced vocational training” (p. 234). According to Hossler and Gallagher (1987), students’ backgrounds, attributes, activities (e.g., academic ability, gender, socioeconomic status, parental education, etc.), and institutional characteristics interact to influence the college choice decision.

During the predisposition phase, students go through a developmental process in which they "determine whether or not they would like to continue their education beyond high school” (Hossler \& Gallagher, 1987, p. 209). Students become predisposed toward or interested in attending college as they develop educational and occupational aspirations (Hossler \& Gallagher, 1987). During the second stage, students search for information about colleges (Hossler \& Gallagher, 1987). Researchers who have examined the search stage typically operationalize "search" in terms of college related information that students and parents use and/or the number of colleges that students consider or to which they apply (Hossler et al., 1998). During the third stage, students decide to enroll in a particular college or university. 
This model works best for traditional college students and for students who enroll in college immediately after graduating from high school; the predisposition occurs between the $7^{\text {th }}$ and $10^{\text {th }}$ grades, search during the $10^{\text {th }}$ and $12^{\text {th }}$ grades, and choice during the $11^{\text {th }}$ and $12^{\text {th }}$ grades (Hossler et al., 1999). Hossler and Gallagher (1987) acknowledged the role of institutional influence from a student's high school and from the colleges and universities to which the student is exposed. This influence includes having a college prep curriculum and access to co-curricular and extra-curricular activities at the high school, the proximity of a college campus, and ways in which students are able to interact with students at different colleges and universities (Duncan, 2013). These researchers also discussed how financial aid policies created on federal and state levels can provide information to families concerning the cost of pursuing postsecondary education.

Freeman (2005) argued that expanding the 1987 Hossler and Gallagher model to include influences based on "family and kinship" and "school characteristics" would be useful when considering the college choices made by African American students. Family structures and the way African Americans interact with different types of schools are important factors to understand. If culture and the family background of these students are not accounted for, then factors influential to their college choice are difficult to interpret (Freeman, 2005).

Smith and Fleming (2006) concluded that boundaries in Hossler and Gallagher's model should be more relaxed when applied to students of color. Smith and Fleming observed that if college administrators fail to acknowledge the influence that parents of 
color have on their children's college choice, these administrators may miss the opportunity to enroll students of color.

In contrast to the Hossler and Gallagher model, Perna’s (2006) multilevel model of college access allows for differences in the college choice process as that process is experienced by different individuals and members of different groups, such as Blacks or students from low-income families. Perna’s model, introduced in her 2006 paper “Studying College Access and Choice: A Proposed Conceptual Model,” expanded Hossler and Gallagher's model to a layered framework. 


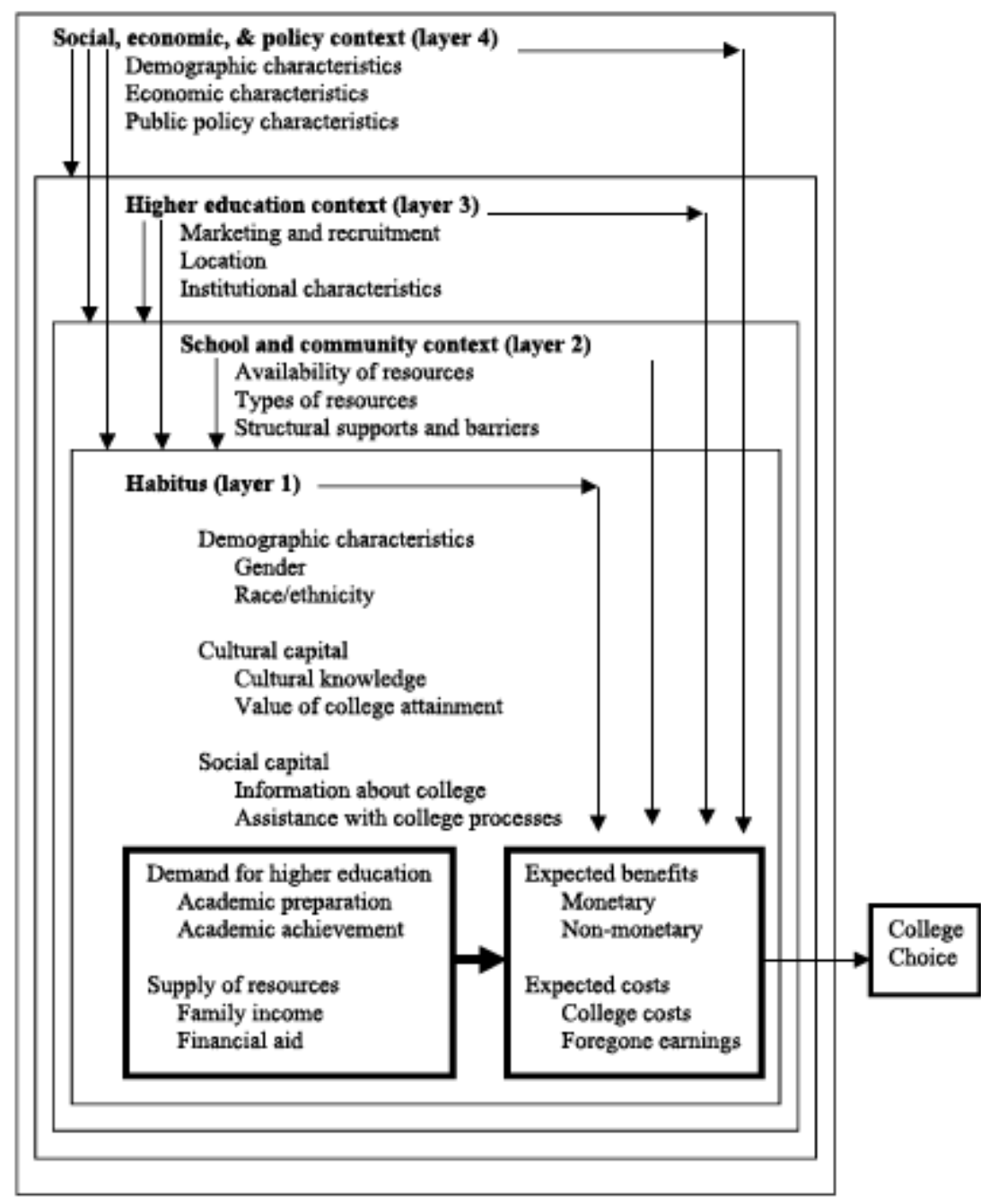

Figure 2.1 Perna (2006) Proposed Conceptual Model of Student College Choice

(Perna, 2006, p. 117.)

Perna proposed that college choice occurs within four layers of context: (1) habitus, (2) school and community context, (3) higher education context, and (4) social, economic, and policy context. Perna’s model “draws on an economic model of human capital investment as well as sociological concepts of habitus, cultural and social capital, and organizational context” (p. 116). This model has two assumptions: (1) enrollment 
decisions reflect the student's situated context and (2) multiple routes can lead to college enrollment (Perna, 2006).

The human capital investment model is at the center of Perna's model. Making a decision to attend college involves weighing the expected costs against the expected benefits. The two calculations are influenced by student academic preparation and achievement and the student's access to financial resources to pay for college (Perna, 2006). This model recognizes how individual differences and varying contexts influence students' college choice (Perna, 2006). The first layer, individual habitus, consists of an individual's internalized systems of thoughts, beliefs, and perceptions that are acquired from the immediate environment, and the individual's college related expectations, attitudes, and aspirations (Bourdieu \& Passerson, 1977). Habitus includes the student’s demographic characteristics, gender and race/ethnicity, and social and cultural capital. A student's college choice reflects the values and knowledge gained from parents and other close family members and friends. The amount of knowledge gained often varies in relation to socioeconomic status and access to information about higher education (Duncan, 2013).

The second layer of the Perna model looks at the impact of the school and community. The school and community contexts reflect McDonough's notion of “organizational habitus,” which recognized ways in which social structures and resources facilitate or impede college choice. For low-income students and racial/ethnic minorities, these contexts may restrict access to college materials. Though we often view teachers and counselors as sources of knowledge and information concerning higher education, these professionals may have dual roles in the school, causing them to be unavailable as 
mentors for students (Stanton-Salazar, 1997). The structures of some high schools create barriers in the college choice process for students of color and low-income students (Perna, 2006). Students in high schools less oriented to preparing students for college will possibly encounter obstacles when attempting to obtain transcripts, collect recommendation letters, meet with guidance counselors, complete application forms, etc. (Stanton-Salazar, 1997). As a consequence, students in these schools may lose confidence in their ability to navigate the college choice systems, or they may miss out on opportunities for scholarships and other funding opportunities.

The third layer of the Perna model recognizes the role that higher education institutions play in shaping college choice (Perna, 2006). Higher education may influence the college choice process in several ways. Higher education institutions can provide information to students and families. An institution's location and geographic proximity to a student may influence choice, as parents and students may need to consider transportation costs associated with traveling home during school breaks. Higher education institutions can also provide information through marketing and recruiting efforts. Recruitment and marketing materials sometimes target middle-income and higher-income students and families. When students of color view these materials, they may not immediately connect with the institution because they do not see anyone who looks like them (Duncan, 2013).

Finally, Perna’s (2006) model addresses the influence of social, economic, and policy contexts on the college choice process. This layer acknowledges the direct and indirect effect that changes in social forces, economic conditions, and public policies will have on college choice. The types of messages regarding higher education from the K-12 
systems, state agencies, and postsecondary institutions themselves play a role in how students receive information, prepare for college, and make college choice decisions (Perna, 2006). The messages can be positive or negative and may be received differently based on background and social status. Perna (2006) recognized that there is more to the college choice process than just weighing the costs and benefits. She stated:

College choice is ultimately based on the comparison of the benefits and cost of enrolling, and assessments of the benefits and costs are shaped not only by the demand for higher education and supply of resources to pay the cost but also by individual habitus and, directly and indirectly, by family, school, and community context, higher education context, and social, economic, and policy context (p.119).

Perna's proposed model addresses multiple contexts not fully considered in Hossler and Gallagher's 1987 model. Her contexts include background characteristics, measures of cultural and social capital, and campus environment (i.e., HBCU or nonHBCU). Because these characteristics are, on average, different for Black Americans than for White Americans, Perna's model provides the granularity and flexibility needed for a study that, while respecting generic analyses of college choice, needs to study the phenomenon from a perspective specific to African American enrollees. Using parts of Perna's model for this current study will help determine what factors predict African American students' decision to enroll either in an HBCU or in a non-HBCU.

\section{Summary of Chapter II}

Due to significant differences in history and in average human, cultural, and social capital, African Americans operate from a unique framework when making their 
college choice decision. Most studies and models for college choice consider the problem generally, disregarding what sets African Americans apart. Those studies that do consider the unique circumstance of Black students choosing a college have not focused sharply on a binary component of the Black students' choice decision: Do I enroll in an HBCU or a non-HBCU? Using Perna's (2006) multilevel model of college access as an improvement over Hossler and Gallagher’s (1987) seminal work, I can explore not only how African American students make their college choice, but also how economic, personal, and sociological factors play a role in their decision. Although Hossler and Gallagher's model outlined the college choice process without considering a student's cultural background or the contexts within which he or she acts, framing the process with Perna’s 2006 model compensates for the deficiencies in the seminal model. This study explores factors that predict African American students' college choice decisions to attend an HBCU or a non-HBCU. My expectations are that choosing one or the other will be found to correlate to significant differences in economic, personal, and sociological characteristics. 


\section{CHAPTER III}

\section{Introduction}

As stated in Chapter I, the purpose of the present study is to provide additional empirical research on African American students and their decision to attend either an HBCU or a non-HBCU. The study examines how various student background characteristics and economic and sociological factors influence college choice. The literature review in Chapter II helped to identify the foundation for the present work and to show how this dissertation will contribute to the empirical research on African American students and college choice. I owe a special debt to the theoretical framework provided by Perna’s (2006) “Studying College Access and Choice: A Proposed Conceptual Model” and that paper’s multilevel model of college access, reproduced in Chapter II.

This chapter describes the data source, instruments used, methodology, and the plan for data analysis.

\section{Data Source}

For this study, I used a national study to investigate why African American students choose to enroll in an HBCU or a non-HBCU. This question was answered based on a series of independent variables using logistic regression analysis. Data for the study has been collected from incoming freshmen at colleges and universities across the nation, using responses to The Freshman Survey (TFS), administered annually since 1966 by the Higher Education Research Institute (HERI) as part of its Cooperative Institutional 
Research Program (CIRP). HERI is based in the Graduate School of Education \& Information Studies at the University of California, Los Angeles. CIRP designs and administers numerous studies of the American higher education system.

Results from 2015’s TFS were the most current results available to researchers at the time of this writing. TFS covers a range of student characteristics such as parental income and education, ethnicity, financial aid, secondary school achievement and activities, educational and career plans and values, attitudes, beliefs, and self- concept. TFS is an appropriate survey to use for this study because of the large sample of students and the wide range of student characteristics and other factors that may influence college choice decisions by African American students who enrolled in either HBCUs or nonHBCUs. Perna’s (2006) “Studying College Access and Choice: A Proposed Conceptual Model” singled out TFS as offering "some advantages for researchers interested in examining the college choices of students at particular types of colleges and universities, including Historically Black Colleges and Universities...” (p. 125). The TFS data was retrieved from the Higher Education Research Institute at UCLA, scanned at CIRP, entered into the SPSS statistics application, version 25, and then sent to me for further analysis.

The current study included secondary analysis of 2015 TFS data using descriptive statistics, which listed all the variables included in the study using a cross-tabular frequency distribution; inferential statistics, which verified the associations and identified whether the associations were distinct for the students entering an HBCU or a nonHBCU; and logistic regression, which predicted the logit of an event outcome (dependent variable) from the set of predictors (independent variables). 


\section{Data Sample}

According to CIRP The American Freshman: National Norms Fall 2015, 1,574 institutions of higher education were invited to participate in the 2015 TFS (Eagan et al., 2015). Considering HERI's fee requirements and the excess of administrative tasks colleges and universities must complete when receiving and processing newly arrived freshmen, TFS participation by 199 baccalaureate-granting institutions represents significant buy-in by eligible candidate schools and speaks to the perceived merit of TFS as CIRP has refined the survey over its 50-year history. The 2015 TFS results included responses from 141,189 first-time full-time freshmen. Some twenty HBCUs, both public and private, were among the 199 participating institutions, and responses from 5,504 HBCU first-time, full-time HBCU students were included in the survey results. Of these, 5,212 students self-identified as Black/African-American. The total number of 2015 TFS respondents self-identifying as Black/African-American exceeded 16,000. The 199 institutions were from all regions in the United States. A list of all participating schools is given as Appendix B of this study. The 48-question 2015 TFS is reproduced as Appendix A.

\section{Validity and Reliability}

Content and predictive validity determine the validity of quantitative research or instrumentation. Content validity refers to how well the questions represent all the possible questions available (Creswell, 2009). Predictive or criterion-related validity refers to how well scores on the instrument relate to an outcome or predict a future outcome (Creswell, 2009). Another important aspect of instrumentation is reliability. Reliability indicates that the scores from the instrument are stable and consistent over 
time (Creswell, 2009). The content validity of TSF is reviewed every year by the CIRP Advisory Committee to ensure TFS items measure what they should measure. The role of the advisory committee is to review survey items for appropriateness each year. This process contributes to the instrument's content and validity by utilizing the advisory committee as a panel of CIRP experts (Norwood, 2009).

\section{Data Collection}

TFS was administered during freshman orientation or during registration. College administrators choose to administer the survey to the entire incoming freshman class or to a sample population. The five-page instrument is designed for self-administration under proctored conditions. To allow CIRP to send a follow-up mailing, individuals are asked to respond to the question "Do you give Higher Education Research Institute (HERI) permission to include your ID number should your college request the data for additional research analyses?” HERI maintains strict standards of confidentiality and requires participating colleges to sign a pledge of confidentiality.

Data used for this study were collected by HERI at UCLA. HERI receives data from colleges and universities who pay HERI to process data from their campuses. HERI has strict policies regarding off-site individuals wishing to use CIRP data for research purposes. Their policies specify that all tabulations of CIRP data must be conducted at HERI only; therefore, data for this study was collected by staff at HERI. I submitted my research project proposal to HERI, spelling out in detail which data elements I needed for my analysis. HERI approved my submission, processed the requested data through the SPSS statistics application, version 25, and provided me with files. As noted earlier, the design of my study called for utilizing a survey and statistical analyses to explore the 
factors underlying the decisions of first-year Black college students to choose enrollment either in an HBCU or in a non-HBCU.

\section{Human Subject Review}

TFS participants granted permission for the data to be used in the study. The first page of the survey contained the following statement:

Your participation in this research is being solicited in order to achieve a better understanding of how students are affected by their college experiences. Identifying information has been requested in order to make subsequent mail follow-up studies possible. Your response will be held in strictest professional confidence.

In my request submitted to HERI, I certified that I had obtained prior project approval from the Office of Human Subjects Research at University of Louisville.

\section{Research Questions and Model}

This study used Perna's (2006) multilevel model of college access and the work of other researchers, especially Freeman and St. John, to guide a selection of TFS data most likely to yield statistically significant differences that distinguish Black students choosing an HBCU from those choosing a non-HBCU. The questions the current research sought to answer are:

1 To what extent do certain student background characteristics (e.g., gender, high school type, accepted in first choice, first generation, board score, degree aspirations, and institution control, high school grade) predict the choice to attend an HBCU for African American students, controlling for other key factors? 
2 To what extent do certain economic factors (e.g., parent income, financial concern, need-base grant parental) predict the choice to attend an HBCU for African American students, controlling for key factors?

3 To what extent do certain sociological factors (e.g., parent influence, teacher influence, counselor influence, race composition in high school, race composition in neighborhood, parent education) predict the choice to attend an HBCU for African American students, controlling for other key factors?

Grouped into the three broad categories listed above, the current study is easily seen to mirror the personal, sociological, and financial elements that influence choice of college in the habitus layer of Perna’s multilevel model, reproduced in Chapter II as Figure 2.1. Table 3.1 displays a comparison between Perna's model habitus elements and the current study’s model elements. 


\section{Table 3.1}

Model element comparison

\section{Perna Model Habitus Elements}

Gender

Value of College Attainment

Information about Colleges

Academic Preparation

Academic Achievement

Family Income

Financial Aid

\section{Current Study's Model Elements}

Gender

Career Aspirations, Parent Education

Parent Influence, Teacher/Counselor

Influences, First Generation, Institution

Control, Accepted in First Choice

High School Type and Racial Composition

in High School and Neighborhood

High School Grade Point Average, Board

Score

Parental Income

Need-Base Grant, Financial Concern

Like Perna’s model, the current study's model can be represented schematically: 
Figure 3.1. Conceptual Model of College Choice for African American Students

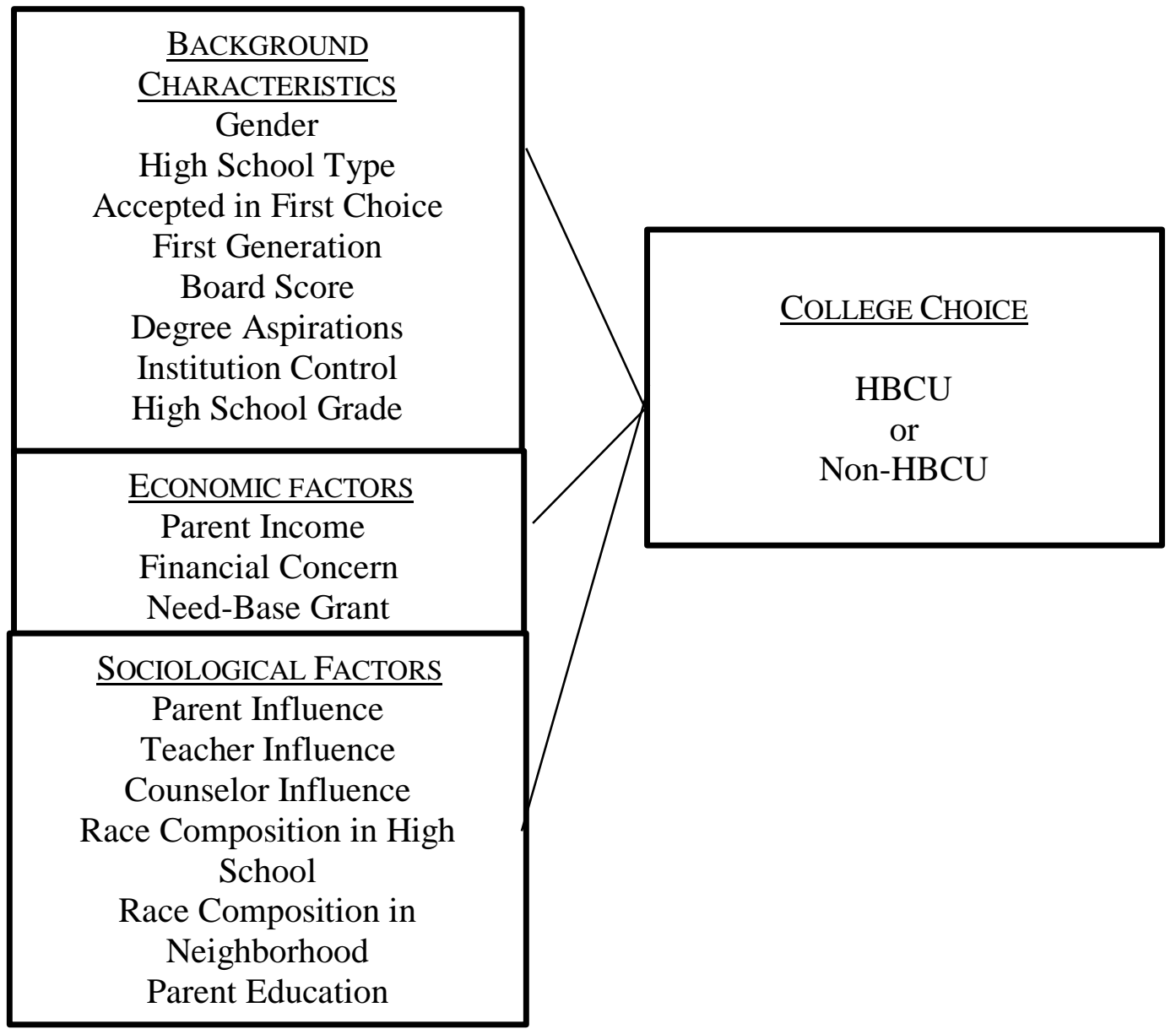

The predictors or independent variables in this model are listed in Table 3.2.

HERI's delivered TFS data provided values for these variables. Chapter IV details how these values and value ranges are coded to enable this study's statistical analysis. For all predictors, the outcome or dependent variable is always HBCU or non-HBCU - the choice made by African Americans enrolling as freshmen. 
Table 3.2 TFS College Choice Variables

TFS

Variable Description

Values

Questions

Background Characteristics

Gender

High School Type

Male, Female

1

Public or Private 9

Accepted in First Choice

Yes or No

14

First Generation

Yes or No

Board Score

ACT Conversion

Selectivity

Degree Aspiration

Bachelor +

8

Institution Control

Public or Private

High School Grade

A thru D

Selectivity

7

Economic Factors

Parent Income

$\$ 10,000$ - \$250,000

30

Financial Concern

None thru Some or Major

31

Need-Base Grant

Yes or No

Sociological Factor

Parent Influence

Important - Not important

Teacher Influence

Important - Not important

43

Counselor Influence

Important - Not important

43

Race Composition in High School

Completely White-Non-

White

46

Race Composition in Neighborhood

Completely White-Non-

White

46

Parent Education

No Degree- BA or Higher

36 


\section{Statistical Methods}

Variables were selected by consulting the literature to determine what factors may be relevant to the college choice process for students, and also by reviewing data available in TFS responses that could be used as indices for the various factors. TFS included questions that could be used to represent both economic and sociological factors that influence the college choice decision by African American students entering either an HBCU or a non-HBCU. Demographic items were selected to describe some aspects of the student's individual characteristics.

Independent variables and their coding were aligned as follows with the research questions:

\section{Table 3.3}

Variable Coding for Binary HBCU College Choice Model

\section{Variables}

Background Characteristics

Gender

High School Type

Accepted in $1^{\text {st }}$ Choice

First Generation

Board Score

Degree Aspiration

bachelor

Institution Control

High School Grade

Economic Factors

Need-Base Gran

Financial Concern

Parent Income

75,000+

Sociological Factors

Parent Education

\section{Coding}

$$
\begin{aligned}
& \text { Coded } 0=\text { male, } 1=\text { female } \\
& \text { Coded } 0=\text { private, } 1=\text { public } \\
& \text { Coded } 0=\text { no, } 1=\text { yes } \\
& \text { Coded } 0=\text { yes, } 1=\text { no } \\
& \text { SAT converted to ACT } \\
& \text { Coded } 0=\text { less than bachelor, } 1= \\
& \text { Coded } 0=\text { Private, } 1=\text { Public } \\
& \text { Coded } 0=\text { B and above, } 1=\text { B-or less }
\end{aligned}
$$

Coded $0=$ no, $1=$ yes

Coded $0=$ some or major, $1=$ none

Coded $0=$ less than $75,000,1=$

Coded 0 = no degree, $1=$ BA or higher 
Parent Influence

important

Teacher Influence

important

Counselor Influence

important

Race in HS

White,

White

Race in Neighborhood

White,

White
Coded $0=$ important, $1=$ not

Coded $0=$ important, $1=$ not

Coded $0=$ important, $1=$ not

Coded $0=$ mostly to completely

1 = completely to roughly non-

Coded $0=$ mostly to completely

1 = completely to roughly non-

Dummy coding was used to create reference level and comparison levels for the categorical variables. Ordinal scales (e.g., Likert scale items) were treated as continuous and did not need dummy coding. Interval variables (e.g., family income) also were continuous (Garcia, 2014). Variables (including dummy levels) were entered into the logistic regression analysis as predictors with binary outcome (enrolled in either an HBCU or a non-HBCU). The analysis used a logistic regression due to the categorical nature of the outcome variable. Logistic regression is a quantitative descriptive design that serves to model the probabilities that various predictor variables will influence the outcome variable. Unlike linear regression, these relationships are not assumed to be linear, and the dependent variable does not have a normal distribution (Menard, 1995).

Other important assumptions of logistic regression are that the sample must be large enough to support the number of included variables to be analyzed and that multicollinearity (or correlation) among the independent variables is limited (Allison, 2001). For the current study, sample size is more than sufficient. HERI reported that of the more than 140,000 students responding in the 2015 TFS, $11.6 \%$ self-identified as 
African American. More than 5,500 responses came from HBCU students, and the African American percentage among those respondents was 94.7\%.

Specific variables included in the model were (a) student background variables $\left(\beta_{1}\right)$ including gender, HS GPA, degree aspiration, HS ACT/SAT, and HS type; first generation; institution control (b) sociological factors $\left(\beta_{2}\right)$ including parental education, and family/high school influences and racial composition of HS and neighborhood; economic factors $\left(\beta_{3}\right)$ did you have concern about your ability to finance your education, parental/guardian total income last year, and need-base grant.

Traditionally these research questions have been addressed by either ordinary least squares (OSL) regression or linear discriminant function analysis. Both techniques were subsequently found to be less than ideal for handling dichotomous outcome due to their strict statistical assumptions (i.e., linearity, normality, and continuity for OLS regression and multivariate normality with equal variances, and equal variances and covariances for discriminate analysis) (Peng et al., 2002).

The central mathematical concept that underlies logistic regression is the logit the logarithm of an odds ratio. The simplest example of the logit derives from a 2x2 contingency table. Logistic regression solves problems by applying the logit transformation to the dependent variable. The logistic model predicts the logit of Y from $\mathrm{X}$. The logit is the natural logarithm (ln) of odds of $\mathrm{Y}$, and odds are ratios of probabilities $(\pi)$ of Y happening. Logistic regression can accommodate categorical outcomes. The simplest logistic model has a form:

$$
\begin{gathered}
\operatorname{Logit}(\mathrm{Y})=\text { natural } \log (\text { odds })=\ln =\pi \\
1-\pi=\alpha+\beta x
\end{gathered}
$$


In the equations, $\pi$ is the probability of the outcome of interest or event and $\mathrm{x}$ is the $\mathrm{Y}$ intercept and $\beta$ is the regression coefficient; $\mathrm{X}$ can be categorical or continuous, but $\mathrm{Y}$ is always categorical. Stevens (2009) reported that in logistic regression the dependent variable is dichotomous: that is, it has only two values and these often are coded as 0 and 1. Two important things to note regarding logistic regression: (1) The relationship between the predictor(s) and the dependent variables is nonlinear, and (2) The regression coefficients are estimated using maximum likelihood.

\section{Data Analyses}

The data from TFS 2015 were analyzed to determine which of the questions (Appendix A) would be best suited to represent the independent variables. Missing data were removed from the analysis by listwise deletion. In terms of collinearity among predicting variables, Vaughan and Berry (2005) suggested that if collinearity exists, probably the variance, standard error, and parameter estimates are all inflated. A viable remedy for the detection of multicollinearity (a condition in which a set of predictor variables are highly correlated among themselves) is using a Variance Inflation Test (VIF). By examining the size of the VIF for each of the variables, the researcher can then

decide which of the independent variables are redundant and should be dropped from the study (Miles \& Shevlin, 2001). The closer the VIF is to 10, the less collinearity there would be (Foster, et al., 2006).

The study used logistic regression methods to determine how the predictor variables are related to college choice based on the conceptual framework developed in the study. Logistic regression implies that the same probability is maintained across a range of independent variables. In the present study, logistic regression was used to 
examine factors that influenced African American students' college choice to enroll in an HBCU or a non-HBCU.

Institutional characteristics were provided in the data received from HERI. Due to the possible small number of HBCUs, logistic regression was chosen as a preferred method of analysis. Student background variables, sociological and economic factors were examined. Consider an instance in which the distribution of a dichotomous outcome variable (African American students and the choice to attend an HBCU) is paired with a dichotomous predictor variable (gender). One might assess a woman's odds of enrolling in an HBCU relative to a man's odds. Generally, logistic regression is well suited for describing and testing hypotheses about a relationship between a categorical outcome variable and one or more categorical or continuous predictor variables. The results could be an odds ratio which suggests that women are more likely, or less likely, to attend an HBCU compared to men.

Descriptive statistics were prepared as the first step in the analysis. Descriptive statistics were used to identify differences in characteristics among African American men and women enrolled at HBCUs or non-HBCUs in fall 2015. In order to address the research questions, both descriptive and logistic regression analyses are reported to help the researcher come to conclusions such as estimates, generalizations, decisions, or predictions about a population on the basis of data (Vogt, 1999).

Frequencies, means, a correlations custom table, and cross tabulations were employed for each of the groups. Logistic regression was then conducted. The coefficients can be interpreted either as log odds, odds, or probabilities that the outcome will change with alternations in a given predictor variable (Menard 1995; Pampel, 2000). 
The Wald (to test an odds ratio) test is analogous to the t-test in multiple regression and is used to see if the regression coefficient (or beta weight) is statistically significant (Huck, 2000). The Wald test evaluates the fit of the variables in a logistic regression model compared to a model with only a constant term. Goodness-of-fit statistics such as likelihood ratio show how effective the fitted model is in describing the research data. Evaluations were made for the percent of correct predictions of the outcome by the model, as compared to how the outcome was distributed in the observed data.

As noted earlier, this was a quantitative study utilizing a survey and descriptive statistical analyses to determine the background characteristics, economic and sociological factors of first-year, incoming students enrolled in HBCUs or non-HBCUs in 2015.

\section{Limitations of This Study}

As with all research, there are some limitations. First, the data underlying the study were drawn from self-reporting students enrolled in specific 4-year HBCUs and non-HBCUs. Because the sampling was non-random, to interpret the study's findings as though they apply to all first-year Black college students and to all colleges, HBCUs and non-HBCUs, is to over-generalize. Second, although The Freshman Survey has been refined and improved over a full half-century, the survey retains the inherent limitations of any voluntary self-reporting instrument. Do those who elect to respond represent accurately the target population as a whole? Have the respondents responded honestly, without regard for maintenance of a self-image? Do they have the capacity for introspection necessary to make an honest response? Do the survey questions evoke in all respondents the same understandings and interpretations? Third, TFS data are limited to 
individuals who actually enroll in college, and thus they provide only retrospective information about the college-choice process. Fourth, survey responses do not report all institutions an individual applied to prior to selecting a college for enrollment.

Researchers must recognize other challenges and limitations associated with using secondary data (St. John, 2004) that are based on survey instruments. Questions on the survey constitute only limited measures of complex constructs such as cultural and social capital (Perna, 2000; Perna \& Titus, 2007).

While using TFS's national survey data set was a major strength of this study, the absence of some important information nevertheless prevented a full application of the study's conceptual model. Like most nationally collected data created for general or multiple purposes, the TFS data set did include many variables desirable for my study. The data lacked specific questions about parental encouragement or involvement in the college choice decision. The only related survey question asked for "reasons that might influence your decision to attend a particular college.” The only response choice that considered parental encouragement or involvement was "my parents/relatives wanted me to come here.” As a transmitter of social capital, parents play a critical role in students' college choice processes. One way by which parents promote college choice is through their involvement in their children's education (Perna, 2006). Also omitted from the survey were specific questions in other subject areas significant for my model: the expected benefits of college, college costs, and forgone earnings. A final limitation to the study was missing data. Missing data can occur when survey respondents fail to answer specific questions. Missing data are a common occurrence and can have a significant effect on research conclusions that can be drawn. 


\section{Summary of Chapter III}

Adapting Perna's 2006 model to provide a theoretical framework, the current study has based its findings on data collected by UCLA’s Higher Education Research Institute (HERI) in the 2015 iteration of the Institute's Freshman Survey (TFS). More than 16,000 respondents in the 2015 TFS self-identified as Black/African-American. Freshmen at HBCUs accounted for more than 5,500 of the TFS responses. I requested and received from HERI response data for those TFS questions relevant to my investigation of student background characteristics and economic and sociological factors expected to influence Black students’ decisions to select either an HBCU or a non-HBCU. The received response data, processed through version 25 of the SPSS statistics application, was then analyzed using logistic regression. 


\section{CHAPTER IV}

\section{Introduction}

This study utilized archived data from The Freshman Survey of 2015, obtained from the Higher Education Research Institute (HERI) at University of California at Los Angeles. The survey offered a national sample of students who entered a post-secondary institution for the first- time full-time in the 2015-2016 academic year. The institutions were classified into 26 stratification groups based on type, institutional control, race (predominantly non-Black, predominantly Black), and the selectivity level of the institution. Selectivity was defined by the median SAT Verbal and Math scores (or ACT composite score) of the entering class.

A list of the schools participating in the survey and each school's stratification group assignment can be found in Appendix B. In the survey results, 23,315 students who began their postsecondary education at 4-year institutions in 2015 self-identified as Black. Of these, 14,865 (63.8\%) students had enrolled in non-HBCUs and 8,450 (36.2\%) had enrolled in HBCUs. Gender distribution was 13,903 (60\%) women and 9412 (40\%) for men.

The study used variables that have been recognized as factors influencing student college choice, acknowledging that the influence of these variables may differ depending on the data, the research methodology, and the research instrument. The decision to attend either an HBCU or a non-HBCU is viewed as a function of three categories: student background characteristics, sociological factors, and economic factors. The current study's research questions detail those categories with specific variables. 


\section{Research Questions}

1. To what extent do students' background characteristics, specifically gender, high school type, accepted in first choice, first generation, board score, degree aspiration, institution control, high school grade predict the choice to attend an HBCU for African American students, controlling for other key factors?

2. To what extent do economic factors, specifically parent income, financial concern, need-based grant predict the choice to attend an HBCU for African American students, controlling for other key factors?

3. To what extent do sociological factors, specifically parent influence, teacher influence, counselor influence, race composition in high school, race composition in neighborhood, parent education predict the choice to attend an HBCU for African American students, controlling for other key factors?

In analyzing which variables predict the choice to attend an HBCU for African American students, controlling for other key variables, two analytical steps were conducted. First, descriptive statistics described features of the collected data: frequencies (number of occurrences) and measures of central tendency (dispersion and percentiles). Cross-tabulation or cross tables displayed frequency distribution of the variables; custom tables organized information into rows and columns, and correlations between two or more variables disclosed relationships or associations used for further analysis. Second, three sequential logistic regression models were conducted, examining which variables influence African American students to attend an HBCU. Model 1 included the student background characteristics. In model 2, the economic factors were entered into the equations, and model 3 added the sociological factors. These three 
sequential models made it possible to examine the direct effects and the relationships among the individual variables. Logistic regression estimates how various factors influence the probability of an occurrence of a dichotomous outcome variable, in this case, whether students attend an HBCU or attend a non-HBCU. The coefficients for each variable identified the relationship between a unit change in a predictor and the estimated percentage change in the outcome variables. For example, the odds ratio of attending an HBCU for females was 1.13 times more likely than the odds ratio for men. Also, there were decreases in the coefficient forty-eight-point difference for parent income. Blocks 2 and 3 reported an increase in parent income from 0.594 to 0.624 thirty points less likely of African American students attending an HBCU. Adding parent income into Block 3 changed the odds ratio, controlling for other variables in the model.

Four indicators were used to verify the quality and fit of the statistical models presented in this study: the - 2 log likelihood, chi square, the percentage of cases correctly predicted, and pseudo $\mathrm{R}^{2}$. The increases in the chi square and the decreases in $2 \log \mathrm{L}$ represent an improved model. The percentage of cases correctly predicted indicates how well the model predicts the individual cases: the higher the percentage, the better the predictive model. The pseudo $\mathrm{R}^{2}$ indicates the goodness-of-fit of the model. The results for this study are given below.

\section{Descriptive Results}

In data obtained from The Freshman Survey 2015, 64\% of African Americans surveyed attended a non-HBCU and 36\% attended an HBCU. As shown in Table 4.1, the percentage distribution of students attending an $\mathrm{HBCU}$ and a non-HBCU across groups showed statistically significant differences at the .05 level. Both populations were 
typically not accepted in their first choice of college. Approximately 92\% of HBCU students had attended public high schools, compared to $81 \%$ for non-HBCU students. In addition, 27\% of HBCU students had recorded a high school grade point average B or above, while the percentage for non-HBCU students was 15\%. Parental influence was important in the college choice decision for 59\% of HBCU students, compared to 54\% for non-HBCU students. Approximately 24\% of HBCU students reported living in a completely to roughly non-White neighborhood, compared to $15 \%$ of students at nonHBCUs. In addition, 50\% of HBCU students reported they received one or more needbased grants, compared to $36 \%$ of non-HBCU students, and $62 \%$ of HBCU students reported enrolling in a public institution compared to 39\% of non-HBCU students. These differences in the distribution of African Americans attending an $\mathrm{HBCU}$ or a non-HBCU were statistically significant.

Chi-square tests were used to analyze differences in relative proportions of binary variables (e.g., gender) between HBCU and non-HBCU students. As seen in Table 4.1, the chi-square tests were significant for gender (chi square $=12.55, d f=1, p=<.05$ ), high school type (chi square $=486.738, d f=1, p=<.05$ ), accepted in first choice (chisquare $=24.177, d f=1, p=<.05$ ), degree aspiration (chi square $=53.020, d f=1, p=$ $<.05$, first-generation (chi square $=13.820, d f=1, p=<.05$ ), high school grade (chi square $=486.958, d f=1, p=<.05$ ), parent education (chi square $=14.884, d f=1, p=$ $<.05$, parent choice (chi square $=52.984, d f=1, p=<.05$, race in high school (chi square $=150.090, d f=1, p=<.05$, race in neighborhood (chi square $=258.876, d f=1, p$ $=<.05$ ), need-base grant (chi square $=432.993, d f=1, p=<.05$ ), parent income (chi square $=248.799, d f=1, p=<.05$ ), institution control (chi square $=1143.627, d f=1, p=$ 
$<.05$ ), indicating that the differences in relative proportions of the two levels of those variables between $\mathrm{HBCU}$ and non-HBCU students were greater than expected by chance. Similarly, an independent samples t-test was conducted to analyze mean differences on board score between HBCU and non-HBCU students. Table 4.1 shows that non-HBCU students had significantly higher board scores than HBCU students ( $\mathrm{t}=5.015, d f 16319$, $p=.05$. No other chi-square tests were statistically significant. To examine these probabilities, logistic regression analyses were conducted. 
Table 4.1

Descriptive Results

\begin{tabular}{|c|c|c|c|}
\hline \multirow[t]{2}{*}{ Descriptive Statistics } & & \multirow{2}{*}{$\begin{array}{l}\text { Non-HBCU } \\
\text { Column \% }\end{array}$} & \multirow{2}{*}{$\begin{array}{l}\text { HBCU } \\
\text { Column \% }\end{array}$} \\
\hline & & & \\
\hline \multirow[t]{2}{*}{ Gender * } & Male & 0.41 & 0.39 \\
\hline & Female & 0.59 & 0.61 \\
\hline \multirow[t]{2}{*}{ High School Type * } & Public & 0.81 & 0.92 \\
\hline & Private & 0.19 & 0.08 \\
\hline \multirow[t]{2}{*}{ Accepted in First Choice* } & Yes & 0.29 & 0.26 \\
\hline & No & 0.71 & 0.74 \\
\hline \multirow[t]{2}{*}{ First Generation* } & Yes & 0.21 & 0.23 \\
\hline & No & 0.79 & 0.77 \\
\hline Board Score* & Board Score & 27.80 & 23.53 \\
\hline \multirow[t]{2}{*}{ Degree Aspiration* } & Bachelor + & 0.91 & 0.89 \\
\hline & Less than a Bachelor & 0.09 & 0.12 \\
\hline \multirow[t]{2}{*}{ Institution Control* } & Public & 0.39 & 0.62 \\
\hline & Private & 0.61 & 0.38 \\
\hline \multirow[t]{2}{*}{ High School Grades* } & B and above & 0.15 & 0.27 \\
\hline & B- and below & 0.85 & 0.73 \\
\hline \multirow[t]{2}{*}{ Parent Income* } & Less than $\$ 75,000$ & 0.60 & 0.70 \\
\hline & $\$ 75.000+$ & 0.40 & 0.30 \\
\hline \multirow[t]{2}{*}{ Financial Concern } & None & 0.78 & 0.78 \\
\hline & Some or major & 0.22 & 0.22 \\
\hline \multirow[t]{2}{*}{ Need-Base Grant* } & Yes & 0.36 & 0.50 \\
\hline & No & 0.64 & 0.50 \\
\hline \multirow[t]{2}{*}{ Parent Influence* } & Not important & 0.54 & 0.59 \\
\hline & Important & 0.46 & 0.41 \\
\hline \multirow[t]{2}{*}{ Teacher Influence } & Not important & 0.38 & 0.38 \\
\hline & Important & 0.62 & 0.62 \\
\hline
\end{tabular}




\begin{tabular}{llll} 
Counselor Influence & Not important & 0.42 & 0.42 \\
& Important & 0.58 & 0.58 \\
Race in High School* & Completely White & 0.91 & 0.86 \\
& $\begin{array}{l}\text { Roughly to non- } \\
\text { White }\end{array}$ & 0.09 & 0.14 \\
Race in Neighborhood* & Completely White & 0.85 & 0.76 \\
& Roughly to non- & 0.15 & 0.24 \\
Parent Education* & White & 0.32 & 0.34 \\
& No Degree & 0.68 & 0.66 \\
\hline
\end{tabular}

Note: * Chi-square test of proportions was statistically significant $(p<.05)$; +Independent Samples T-Test was statistically significant $(p<.05)$.

\section{Logistic Regression Results}

Logistic regression was utilized because of the dichotomous nature of the dependent variable: (1) attended an HBCU, (0) attended a non-HBCU. Each of the three tests of model coefficients had a significance chi-square value 0.05 level. Additionally, the increases in chi square and the reduction in the - 2-log L statistic in each successive logistic showed that the added variables in the models increased or decreased the likelihood of attending an HBCU. The final model correctly predicted $65.2 \%$ of attending an HBCU.

\section{Effects of Background Characteristics on Students' College Choice to Attend an HBCU}

In Model 1, background characteristic variables were entered into the equation: gender, high school type, accepted in first choice, first generation, board score, degree aspiration, institution control and high school grades. Based on the background characteristics, the odds ratio of attending an $\mathrm{HBCU}$ for women was 1.15 times more 
likely than the odds ratio for men, controlling for other variables in the model. The odds ratio of attending an HBCU for students not accepted in their first choice was 1.25 times more likely than for students accepted in their first choice, controlling for other variables in the model. The odds ratio for board score was 1.00, indicating that a one-point increase in board score was not associated with a change in the odds ratio of attending an HBCU, controlling for other variables in the model. The odds ratio of attending an HBCU for students with a B- or below high school grade-point average was 2.18 times more likely than the odds ratio for students with a B and above high school grade-point average, controlling for other variables in the model. Most of the variables were significant at the .05 levels except for first generation (.102\%). In addition, the remaining variables’ odds ratios of attending an HBCU - high school type, first-generation, degree aspiration and institution control - were less than 1 and were less likely to attend an HBCU, controlling for other variables in the model. The research question asked what background characteristics predict enrollment in an HBCU. The odds results indicated that gender, accepted in first choice, board score and high school grade had better odds of attending an HBCU, controlling for other variables in the model.

\section{Effect of Economic Factors on Students' College Choice to Attend an HBCU}

When the economic variables were added in Model 2, the three additional variables were parent income, financial concerns and need-based grant. In addition to the added variables, first-generation odds ratio increased the likelihood of attending an HBCU compared to Model 1, and the significance increased when the additional variables were added in the equation. The odds ratio of attending an HBCU for women decreased from 1.15 to 1.12 times more likely than the odds ratio for men, controlling for 
other variables in the model. The odds ratio for attending an HBCU for students not accepted in their first choice decreased from 1.25 to 1.22 times more likely than the odds ratio for students accepted in their first choice, controlling for other variables in the model. The odds ratio of attending an HBCU and being first generation increased by 1.00 , indicating that a one-point increase in first generation was not associated with a change in the odds ratio of attending an HBCU, controlling for other variables in the model. The same odds ratio for board score was 1.00, indicating that a one-point increase in board score was not associated with a change in the odds of attending an HBCU, controlling for other variables in the model.

In addition, the odds of attending an HBCU for students with a B- or below high school grade-point average decreased from 2.18 to 2.08 times more likely than the odds ratio for students with a B and above high school grade-point average, controlling for other variables in the model. The odds ratio of attending an $\mathrm{HBCU}$ for students not receiving a need-based grant was 1.84 times more likely than the odds of students who received a need-based grant, after controlling for other variables in the model. Additionally. the remaining variables' odds ratios of attending an HBCU - high school type, degree aspiration, institution control, parent income and financial concern - were less than 1 and were less likely to attend an HBCU, except for first- generation in Model 1 , controlling for other variables in the model. The research question asked what economic factors predict enrollment in an HBCU. The odds ratio results reported gender, accepted in first choice, first-generation, board score, high school grade and need-based grant had greater odds ratios of attending an HBCU, controlling for other variables in the model. 


\section{Effect of Sociological Factors on Students' College Choice to Attend an HBCU}

When the sociological variables were added in Model 3, six additional variables were added to the equation: parent influence, teacher influence, counselor influence, racial composition in high school, racial composition in the student's home neighborhood, and parent education. The odds ratio of attending an HBCU for students who reported teacher influence was unimportant was 1.16 times more likely than the odds ratio for students who reported teacher influence was important, controlling for other variables in the model. The odds ratio of attending an HBCU for students who reported counselor influence was unimportant was 1.01 times more likely than the odds ratio of students who reported counselor influence was important, controlling for other variables in the model. The odds ratio of attending an HBCU for students who reported their racial composition in high school as being mostly to completely White was 1.4 times more likely than the odds ratio of students who reported attending a completely to roughly nonWhite high school, controlling for other variables in the model. The odds ratio of attending an HBCU for students who reported their neighborhood racial composition as being mostly to completely White was 1.62 times more likely than the odds ratio for students who grew up in a completely to roughly non-White neighborhood, controlling for other variables in the model.

In Model 3, out of seventeen variables, most of the variables were significant at the .05 level except for first-generation, financial concern, counselor influence and parent education. In addition, the remaining variables' odds ratios of attending an HBCU - high school type, degree aspiration, institution control, parent income, financial concern, 
parent influence and parent education - were less than 1.00 and less likely to attend an HBCU in Models 1, 2 and 3.

When the additional variables were entered into Model 3, the results indicated the odds of attending an HBCU based on the importance of parental influence and parent education were less than 1.00, and students were less likely to attend an HBCU, controlling for other variables in the model. Interestingly, significant interaction effects were found in thirteen variables in Model 3, except for first generation, financial concern, counselor influence, and parent education.

The results in the final model reported gender, accepted in first choice, firstgeneration, board scores, high school grades, need-based grant, teacher influence, counselor influence, and neighborhood and high school racial composition showing better odds of attending an HBCU, controlling for other variables in the model. Firstgeneration, financial concern, counselor influence and parent education were significant at greater than the .05 level. Based on the findings, specific student characteristics and sociological and economic variables had an impact on the choice to attend an HBCU.

The final analytic model involved the probability of attending an HBCU. Logistic was utilized because of the dichotomous nature of the dependent variable: (1) attended an HBCU and (0) attended a non-HBCU. The odds ratios for each of the independent variables were analyzed. Additional results were derived from several model quality statistics (chi square, minus 2-log likelihood, the predictive efficiency of the model, and $\mathrm{R}^{2}$ logs). 
Table 4.2

Logistic Regression Results: Probability of Attending an HBCU

\begin{tabular}{|c|c|c|c|}
\hline & Block One & Block Two & Block Three \\
\hline & Student & Economic & Sociological \\
\hline & Characteristics & Factors & Factors \\
\hline Variables & Odds Ratio & Odds Ratio & Odds Ratio \\
\hline Gender & $1.149 *$ & $1.126^{*}$ & $1.132 *$ \\
\hline High School Type & $0.504^{*}$ & $0.527 *$ & $0.515^{*}$ \\
\hline Accepted in First Choice & $1.254^{*}$ & $1.226^{*}$ & $1.241^{*}$ \\
\hline First Generation & 0.934 & 0.998 & 1.054 \\
\hline Board Score & $0.998^{*}$ & $0.998^{*}$ & $0.998^{*}$ \\
\hline Degree Aspiration & $0.657^{*}$ & $0.670^{*}$ & $0.683 *$ \\
\hline Institution Control & $0.506^{*}$ & $0.558^{*}$ & $0.547^{*}$ \\
\hline High School Grade & $2.187^{*}$ & $2.087^{*}$ & $2.048^{*}$ \\
\hline Parent Income & & $0.594^{*}$ & $0.624 *$ \\
\hline Financial Concern & & 0.94 & 0.933 \\
\hline Need-Base Grant & & $1.842^{*}$ & $1.830^{*}$ \\
\hline Parent Influence & & & $0.734^{*}$ \\
\hline Teacher Influence & & & $1.167^{*}$ \\
\hline Counselor Influence & & & 1.017 \\
\hline Race in High School & & & $1.462 *$ \\
\hline Race in Neighborhood & & & $1.625^{*}$ \\
\hline Parent Education & & & 0.969 \\
\hline \% Correctly Predicted & 60.7 & 62.7 & 65.2 \\
\hline Nagelkerke & 0.099 & 0.13 & 0.151 \\
\hline $\mathrm{N}=23,315$ & 23,315 & 23,315 & 23,315 \\
\hline
\end{tabular}




\section{Summary of Chapter IV}

In summary, the quality of the model chi square at each step was statistically significant at the 0.5 level and a predictive efficiency reached $65 \%$ at the final step. The minus $2 \log$ likelihood was 18889.529 and the $\mathrm{R}^{2}$ at the last step only reached $15 \%$, which was relatively weak, suggesting the conceptual model was not a good fit, which indicated that the data had more similarities than differences for both HBCUs and nonHBCUs.

The odds ratios reported more women, students accepted in first choice, firstgeneration, high school grade, need-base grant, teacher and counselor influence and students with predominately white racial composition in high school and neighborhood were more likely to attend an HBCU than a non-HBCU. In contrast, the odds ratio reported that students with high school type, degree aspiration, institution control, parent income, financial concern, parent influence, and parent education were more likely to attend a non-HBCU than an HBCU. Most of the descriptive results were statistically significant, except for first generation, financial concern, counselor influence and parent education. From cross-tabulation results, it was clear that teacher influence, counselor influence and financial concern determined by chi square were statistically significant. 


\section{CHAPTER V}

\section{Introduction}

A binary logistic regression was conducted to assess the predictive significance of student characteristics and sociological and economic factors for first-time, full-time, freshmen enrolled in Historically Black Colleges and Universities (HBCUs) for fall 2015. The independent variables included gender, high school type, accepted in first choice, degree aspiration, first-generation, high school grades, test scores, parental education, parent influence, teacher influence, counselor influence, racial composition in high school and neighborhood, need-base grant, financial concerns, parent income and institution control. The strength of each predictor for each model was evaluated using the Cox Snell and Nagelkerke's pseudo- ${ }^{2}$ values. Statistical significance of each predictor variable was evaluated using Wald chi-squared test. The following sections analyze the specific findings. This study aimed to provide findings to help policymakers, educator,

parents and students become better informed about factors that influence college choice for African American students.

\section{Student Characteristics}

Student characteristic analysis examined if gender could predict enrollment in an HBCU for first-time full-time student at HBCUs. The binary logistic regression for gender revealed that once this factor was added to the model, the model remained significant $(p=<0.05)$ based on the chi-square analysis. This model indicates that gender was a statistically significant predictor for enrollment in an HBCU. The odds ratio of 
1.132 for female indicated a moderate relationship that females have slightly better odds of being in the target group than do males.

Research on African American females in higher education reveals that the role of HBCUs in educating black women is prominent (Farmer, Hilton, \& Reneau, 2016). Data shows there is an increase in African American females enrolling in postsecondary institutions (Bennett \& Lutz, 2009). In 2009, the U.S. Census reported that 20\% of African American women over the age of 25 held an undergraduate degree (U.S. Census Bureau, 2009). Although the enrollment rate for African American females has doubled over the past decades, distinctive barriers may still be holding enrollments down compared to enrollment rates for White females (Winkle-Wagner, 2015). Research on African American males in higher education reveals that within the entire population of college students, the percentage of Black males in colleges and universities has remained stagnant at $4.8 \%$ over the past four years.

The model also examined if accepted in first choice could predict attending an HBCU. Research by McDonough, Antonio, and Trent (1995) in a quantitative study on African American choice of HBCU revealed that most students applied to three or fewer colleges and about two thirds were accepted at their first choice. However, African Americans are accepted at their first choice less frequently (55\%) than the national average (70\%). The binary logistics for accepted in first choice revealed that once this factor was added to the model, the model remained significant $(p<0.05)$ based on chisquare analysis. This value indicates that acceptance in first choice was a statistically significant predictor for choice. The odds ratios of 1.254, 1.269, 1.241 indicate a 
moderate relationship that students who experienced acceptance in first choice have better odds of not being in the target group.

The model examined if high school type could predict attending an HBCU.

Research on high school type revealed that African Americans attending inner-city public schools are less likely than their counterparts at private high schools to be admitted to a non-HBCU (McDonough, Antonio, \& Trent, 1995). In contrast, students attending predominantly Black schools strongly favored considering non-HBCUs. These students reported a need to share their culture with other groups and wanted a non-HBCU because "the world is not Black" (Freeman, 1999). The binary logistics for high school type revealed that once this factor was added to the model, the model remained significant $(p<0.05)$ based on chi-square analysis. This value indicates that high school type was a statistically significant predictor. The odds ratios of the steps $(0.504,0.496,0.515)$ for high school type indicate a moderate relationship that public high school students have slightly better odds of not being in the target group.

The model examined if high school GPA could predict attending an HBCU. Research by Allen (1992) found that African Americans who attend HBCUs are generally thought to have lower high school GPAs and lower standardized test scores, and to live nearby. Research by Walpole (2008) found that eighty percent of all Black students reported overall averages of B or less, with 27.1\% reporting grades of B or above. However, differences by students' social class background were apparent. The binary logistics for high school GPA revealed that once this factor was added, the model remained significant $(p<0.05)$ based on chi-square analysis. This value indicates that GPA was a statistically significant predictor. The odds ratio of the steps (2.187, 2.134, 
2.048) for high school GPA indicates a moderate relationship that students with GPAs of $\mathrm{B}$ and below have better odds of being in the target group.

The model examined if high school test scores could predict attending an HBCU. The research by Kim and Conrad (2006) found that high school GPA and test scores capture and reflect students' academic preparation and scholastic aptitude. The binary logistics for high school test scores revealed that once this factor was added to the model, the model remained significant $(p<0.05)$ based on chi-square analysis. This value indicates that high school test score was a statistically significant predictor. The odds ratio of 0.998 for test scores (mean 27.78 score for non-HBCU and 23.53 for $\mathrm{HBCU}$ ) indicates a higher-than-mean score not being in the target group.

The model examined if degree aspiration could predict attending an HBCU. Pitre (2006) found that African American students were just as likely to aspire to college as their White peers but had significantly lower academic achievement. Using a logistic regression analysis and controlling for other factors, Perna (2000a) found that African Americans are more likely to enroll in a four-year college or university in the fall after graduating from high school than are their White counterparts. The binary logistics for degree aspiration revealed that once this factor was added to the model, the model remained significant $(p<0.05)$ based on chi-square analysis. This value indicates that degree aspiration was a statistically significant predictor. The odds ratios of $0.657,0.672$, 0.683 indicate a moderate relationship that degree aspiration has slightly better odds of not being in the target group.

The model examined if first generation status could predict attending an HBCU. Research on first generation college students (students for whom neither parent has a 4- 
year college degree) shows that these students earn lower grades and worry more about whether they belong in college, compared with continuing-generation students (who have at least one parent with a 4-year college degree). HBCUs disproportionately enroll lowincome, first-generation and academically underprepared college students - precisely the students that the country most needs to obtain college degrees. In contrast to what was expected, this study revealed that first generation status was not statistically significant when added to the model.

The model examined if institution control could predict attending an HBCU. The data from ACE (2019) reported that public institutions receive a greater proportion of their overall funding from federal, state, and local resources than do private institutions. While public funds are the largest source of revenue for public institutions, private institutions are generally more tuition dependent (i.e., private institutions depend more heavily on tuition and fees for their funding than do public institutions). In 2018 about 76 percent of HBCU students attended public institutions, while the remaining 24 percent attended private nonprofit institutions (NCES, 2019). The odds ratios of 0.506, 0.497, 0.547 for institution control indicate a moderate relationship of public institution enrollees being in the target group.

\section{Sociological Factors}

Sociological factor analysis examined if parental education could predict attending an HBCU. Perna (2000) found that parental educational attainment may reflect parental encouragement for a student's educational attainment as well as the availability of information about how to acquire a college education. Research consistently shows that parental education is an important positive predictor of a variety of college-choice 
outcomes, including educational aspirations and plans and enrollment in either a two-year or four-year college (Ellwood \& Kane, 2000; Hossler et al., 1999; Kao et al., 2005; Stage \& Hossler, 1992). Parental education was added in step 2 and step 3, the odds ratios computed as 0.959 and 0.969 , but parental education was not statistically significant, in contrast to what was expected.

Sociological factor analysis also examined if parent influence or encouragement could predict attending an HBCU. Based on a longitudinal student study of Indiana high school students, Hossler, Schmit, and Vesper (1999) found that parental encouragement is the single most important predictor of students planning to pursue postsecondary education. When measured as parents' expectations for their child's educational attainment, parental encouragement is one of the strongest positive predictors of students' educational plans (Hossler \& Stage, 1989; Hossler \& Stage, 2004). Moreover, parental influence was added in step 2 and step 3, yielding odds ratios of 0.721 and 0.734 . Interestingly, parental influence was statistically significant and indicated a less likely chance of attending an HBCU.

Sociological factor analysis examined if teacher influence could predict attending an HBCU. Some research suggests that support from counselors and teachers may play a relatively more important role in shaping students' actual postsecondary educational decisions, such as the choice of college to attend (Hossler et al., 1999). Research by McDonough (1997) found that high school counselors and teachers also play a role in defining postsecondary education as an acceptable and viable option for students and are potential sources of encouragement to attend college and of assistance with collegechoice processes. Teacher influence was added in step 2 and step 3, the odds ratios 
computed at 1.156 and 1.167. Teacher influence has a moderate chance of being in the target group. In contrast, counselor influence was added to the model at the same steps as teacher influence and was not statistically significant.

Sociological factor analysis examined if race composition in high school could predict attending an HBCU. In 2010 Education Week reported that where students live affects where they go to school, and different type racial groups tend to be concentrated in different types of communities. White students (84\%) are concentrated in suburban and rural communities. Blacks (45\%), Hispanic (56\%), and Asian (13\%) students are most often found in urban and suburban communities. Race in high school was added in step 2 and step 3, yielding odds ratio of 1.477 and 1.462. Predominantly Black race in high school has a moderate chance of being in the target group.

Sociological factor analysis examined if race composition in neighborhood could predict attending an HBCU. Research from the Urban Institute (2018) reported that for every percentage point increase in neighborhood segregation, school segregation increases 1.04 points on average. But the fact that most cities fall above or below the 45degree line says that neighborhood integration is not the only factor. In fact, the research estimated that neighborhood segregation — rooted in a long history of racism and discrimination - explains about 76 percent of the variation in school segregation across cities. Predominantly black neighborhood racial makeup was added in step 2 and step 3, with odds ratio of 1.667 and 1.625 . Neighborhood racial makeup has a moderate chance of being in the target group. 


\section{Economic Factors}

Economic factor analysis examined if need-based grants could predict attending an HBCU. Research by Kane (1999) found that the availability of state need-based financial aid (this includes grants, loans, work-study, and tuition tax credits) is positively related to the likelihood of enrolling in any type of postsecondary education within two years of graduating from high school. Also studied was how need-based aid influences the likelihood of attending an in-state public or private four- year college or university (Perna \& Titus, 2004). Research shows that an offer of financial aid is an important predictor of college enrollment among high school graduates (Catsiapis, 1987). Availability of need-based aid was added in step 3 with all other predictors, yielding an odds ratio of 1.830 . Availability of need-based aid was statistically significant and has a moderate chance of being in the target group.

Economic factor analysis also examined if parent income could predict attending an HBCU. Research shows that family income plays an important role in college choice. Some research suggests that family income is unrelated to educational aspirations (Hossler et al., 1999), whereas other research suggests that family income is positively related to educational aspirations (Kao \& Tienda, 1998). Research also shows a positive relationship between family income, parents' education, and parent occupation, and such measures of college choice as application to a four-year institution (Cabrera \& LaNasa, 2001). Moreover, parent income was added in step 3 with all other predictors, yielding an odds ratio of 0.624 , which was statistically significant. Students with lower parental income were more likely to choose an HBCU. 
Economic factor analysis examined if financial concern could predict attending an HBCU. Research by Freeman (1997) found that African American students were uncertain about their ability to pay the short-term costs of attending and about whether the long-term economic benefits of attending would exceed the costs. The students in this study indicated they had no concerns (77.6\%). Financial concern was added in step 3 with all other predictors, yielding an odds ratio of 0.993. Financial concern was not a statistically significant predictor of a student choosing an HBCU.

The findings related to economic factors in this study indicate that lower parental income and availability of need-based aid are significant predictors of a student choosing an HBCU. Financial concern was not significant, indicating that the financial concerns of students at HBCUs and non-HBCUs do not differ. Together, these findings demonstrate that money matters to all students and families, yet family wealth wields an influence on college choice decisions.

\section{Implications}

This study aimed to provide findings to help policymakers, educators and students become better informed regarding the factors that influence African Americans' college choice to attend an HBCU or to attend a non-HBCU. Using CIRP's The Freshman Survey (TFS) and logistic regression analysis, this study found that attending a nonHBCU and HBCU had somewhat different probabilities, based on independent variables. The descriptive statistics (Table 4.1) showed that many column number percentages and the standardized board score mean did not differ significantly between non-HBCUs and HBCUs. The gender distribution of respondents in both non-HBCUs and HBCUs showed differences in enrollment. About $58.8 \%$ of the students were female and $41.2 \%$ 
were male in non-HBCUs, while $61.1 \%$ were female and $38.9 \%$ were male at HBCUs. I found high school type did differ for the HBCU and non-HBCU groups, which is consistent with previous research that uses high school type as a comparative reference for measure of college choice (McDonough et al., 1995).

Another finding from the study from the descriptive analysis is that a higher proportion of African American students had B- or below GPAs at both non-HBCUs (84.6\%) and HBCUs (72.9\%). Another finding from the study from the descriptive analysis was the teacher and counselor influences, where my results differ from those of previous research. McDonough (1997) found that high school counselors and teachers play a significant role in defining postsecondary education as an acceptable and viable option for students and are potential sources of encouragement to attend college and of assistance with college-choice processes. Some research suggests that support from counselors and teachers may play a relatively more important role in shaping students' actual postsecondary educational decisions, such as the choice of which college to attend (Hossler et al., 1999).

Regarding academic aspirations, Pitre (2006) found that African American students are just as likely to aspire to college as are their White peers. Significantly, these recent studies and my study used different data sets and methods (single level or multilevel regression analysis). It could well be that Black students are adapting to White institutions better today than they were more than a decade ago, not least because of the fact that non-HBCUs are addressing the chilly and discriminatory climate often associated with them (Kim \& Conrad, 2006). Institution control was included in the study to assess what type of institution most African Americans were attending (public or 
private). The descriptive analysis shows that non-HBCU students attend private institutions at a higher rate and HBCU students attend public institutions at a higher rate. It is interesting to note that parent education and racial and high school composition were found to be influential variables in college choice among African American students.

Parental influence was important for both non-HBCU and HBCU students. In describing the effects of families, friends, and other influences on student college choice, McDonough (1997) demonstrated the ways in which schools define student college choice through various organizational structures. The results from the binary logistics analysis suggest that African American students' levels of degree aspiration are slightly higher on non-HBCUs campuses.

\section{Recommendations for Practice}

Logistic regression variance shows only 15\% variance of the possibility of African American students choosing an HBCU instead of a non-HBCU. This indicates that the data points or responses are generally similar and do not vary widely from the mean. Given this result, many recommendations for practice apply both for HBCUs and for non-HBCUs in their recruitment and admission of Black students.

The descriptive statistics show that more women (60\%) than men enrolled in both HBCU and non-HBCU institutions. This finding is consistent with the literature. Both HBCUs and non-HBCUs can employ strategies to recruit more African American men into colleges and universities. High school counselors and college recruiters can partner with Black Male programs (e.g., 100 Black Men, Men of Quality, and Black Male Initiative) within the college institutions or the community to help with recruitment, 
mentoring, serving as role models and ultimately raising college enrollment numbers for African American high school graduates.

In the 1970's, Black churches and local community centers would host college informational sessions and invite alumni and college representatives to talk to potential students, parents, and other family members about the application process, about financial and academic resources, and about the importance of obtaining a college education. Today, recruiters for HBCUs and for non-HBCUs can approach local churches, community centers, and other organizations to create similar college fairs and informational sessions.

Descriptive statistics found that the great majority of both HBCU and non-HBCU first-year students had high school grade point averages of B- or below. The percentage of enrollees with these low GPAs was 73\% for entering HBCU students and almost 85\% for non-HBCU students. This finding presents an opportunity at the same time that it highlights a problem. Practitioners in various roles at multiple institutional and societal levels should address the academic disadvantage African American students experience when faced with the prospect of college. Combined efforts must focus on increasing students' GPAs and board scores. For example, as part of Washington's National Early Intervention Program, parents are spending at least four hours each month in college readiness program activities. Vermont's Early Intervention Program includes home visits, evening presentations, informational sessions, and college and financial aid workshops (Perna, 2007).

Viewing the GPA descriptive statistic from a different angle shows that HBCUs, compared to non-HBCUs, enrolled almost twice the percentage of Black high school 
students with grade point averages of B and higher: 27\% compared to 15\%. This suggests that non-HBCUs were relatively more successful in enrolling African Americans whose high school records showed less promise for post-secondary academic achievement. To better compete for these low-performing high school graduates, HBCUs will want to strengthen remedial programs for incoming freshmen as a means to boost enrollments without lowering retentions.

Operating today under often severe budget constraints, HBCU recruiters face special challenges and must find ways to stretch available dollars. HBCUs may have an advantage over non-HBCUs in alumni relations. Recruiters can use personal contacts and online tools to locate more alumni for use as recruitment officers within the community. This can provide more face-to-face interaction with potential enrollees while minimizing traveling costs for admissions personnel. Also related to budget constraints, HBCU recruiters could review their materials to target students from families with greater wealth, including those who attend private schools.

Descriptive statistics revealed also that only 8\% of HBCU enrollees had graduated from non-public high schools. For non-HBCUs, the figure was significantly higher but still low, at 19\%. All post-secondary institutions, and especially HBCUs, can open new recruitment channels by reaching out to the National Association of Independent Schools and its local affiliates and to church-based school administrations. In recent years, many non-public high schools have embraced diversity as an educational priority and have significantly increased the numbers of their African American students.

Finally, HBCUs compete with one another for students, but they also recognize a shared interest in ensuring that the unique service that HBCUs provide will persist for 
generations to come. Formalizing this shared mission into active collaboration can enable larger investments in web-based and social media communications to student prospects and their parents as well as to high school teachers and counselors. High-quality technological recruiting support is expensive, but, once tools are purchased and developed, they often are shareable at costs that can be lower than the combined costs of individual and inferior go-it-alone technologies.

\section{Recommendations for Research}

Further research should explore pre-college academic preparation for African Americans, which has positive effects on academic success, persistence, and retention at the college level. Do personnel at the elementary, middle, and high school levels provide support and programs (e.g., summer bridge programs, tutoring, etc.) for academically challenged students, regardless of institution type?

More qualitative research is needed to examine factors that influence first-time first-year African American students' college choices. Using the stories of sampled students and weaving their voices into the research literature can provide a unique contribution to educators and policymakers on African American high school students and the college choice process (Freeman, 2005). Researchers, policymakers, and high school and college representatives can benefit from research that can explain and find accommodations for gender differences, which have skewed college enrollment away from African American males.

More qualitative or quantitative research should explore and help expand the role of high school counselors and teachers in African American students' college choice process. In the current study, the majority of both HBCU and non-HBCU students 
reported that counselor and teacher influences were not important in their decision to attend a particular college or university. I believe that African American students' internal motivation to complete a bachelor or higher degree may be more meaningful and influential than are the interactions between students and their teachers and counselors. Most students surveyed said that parental influence, by contrast, was important. More research is required to identify the most effective ways for parents to influence students toward optimal college choice.

There is a need for better data repositories that researchers can use to develop a more comprehensive understanding of African American college choice. The current study's requirement for an HBCU/non-HBCU breakout on college choice led to selecting CIRP’s The Freshman Survey as its primary data source. Perna (2006) singled out The Freshman Survey as offering "some advantages for researchers interested in examining the college choices of students at particular types of colleges and universities, including Historically Black Colleges and Universities...” (p. 125). Future iterations of The Freshman Survey can help researchers by adding questions that probe more deeply into the degrees of influence that parents, teachers, counselors, friends, websites, campus visits, social media, community organizations, and religious-affiliated groups exert on the college choice decision. And other reputable college choice survey instruments can help by discriminating between $\mathrm{HBCU}$ and non-HBCU responses, thereby enabling comparisons of the two groups.

Finally, future research should examine the usefulness of the conceptual model used for this study for understanding differences among African American students and the decision to enroll in a particular 4-year college or university or in a 2-year college. Perna 
(2006) identified four levels of student college choice. My study of the choice decision has sought to adapt Perna's model to make the most effective use possible of data made available in CIRP's The Freshman Survey, focusing on the habitus level. Future studies could explore additional aspects of Perna's model. For example, the social, economic, and policy level could include the current U.S. racial climate, which may exert an influence on African American students' preferences for enrolling at HBCUs, where they may feel more buffered from racism. Replication of my study could produce additional benefits, especially if the study is expanded to address the decisions of Black students who choose to enroll in a two-year or community college. African Americans and Hispanics enroll in these two-year institutions at a higher rate than do Whites. Finally, replication of this study can look for data that probes more deeply than does CIRP's survey into the question of parental influence and involvement in the college choice decision. Bradshaw, Espinoza, and Hausman (2001) shared that 82\% of college bound students reported that parents had influenced their college choice, but researchers have limited information about the interactions between African American students and their parents during the college choice process, and about what African American parents value in institutions of higher education.

\section{Conclusion}

Drawing on two theoretical perspectives, my research has focused on the integrated constructs of economic and sociological perspectives that assume a student's college choice is determined largely by habitus, or the system of values and beliefs that shapes an individual's views and interpretations (Perna, 2006). One key strength of the integrated conceptual model is the assumption that the pattern of educational attainment 
is not universal but varies by racial/ethnic, socioeconomic and other groups (Perna, 2006). This approach addresses the concern raised by Freeman (2005) that policy interventions will not effectively close the gaps in student college choice without recognizing the culture and circumstances of particular groups.

Freeman’s 1997 qualitative study revealed that African American high school students believe that both economic and sociocultural factors restrict the college enrollment of African Americans. Freeman (1997) found that African American high school students were uncertain about their ability to pay the short-term costs of attending and about whether the long-term economic benefits would exceed the costs. The students in Freeman's study pointed to the potential influence of structural barriers such as physical conditions of the schools attended, social capital (e.g., interest and assistance from teachers and counselors, and role models), and cultural capital (e.g., believing at an early age that pursuing postsecondary education was a realistic option). Moreover, measures of cultural and social capital play a relatively more important role in explaining the college enrollment decisions of African Americans (Perna, 2000). While many findings from this study support previous research, they reveal some opportunities for leaders at HBCUs to improve recruitment of future African American students through intentional outreach to public and private high schools (teachers, counselors, and students), community resources (community centers, religiously-affiliated organizations, mentoring programs), and alumni.

\section{Summary of Chapter V}

The characteristics of African Americans choosing to attend an HBCU have been somewhat consistent over time. According to the literature, African American students 
tend to have relatively low GPAs. The same was true in this study sample; $73 \%$ of those who chose an HBCU reported a high school GPA equivalent to B- or less. Educators and policy makers must address the academic disadvantage African Americans confront when entering college, and they must focus on increasing students' GPAs. More research should address prospects and conditions for African American students, thereby providing additional insight that can improve student outcomes. My findings suggest that HBCUs are positioned to elevate African American students despite deficits in precollege preparation and socioeconomic circumstance. This has been the mission of HBCUs since their founding. 


\section{REFERENCES}

Adelman, C. (1999). Answers in the tool box: Academic intensity, attendance patterns, and bachelor's degree attainment. http://files.eric.ed.gov/fulltext/ED431363.pdf

Allen, W. (1992). The color of success: African-American college student outcome at predominantly White and historically Black public colleges and universities. Harvard Educational Review, 62(1), 26-45.

Allen, W. R., Jewell, J. O., Griffin, K. A., \& Wolf, D. S. S. (2007). Historically Black colleges and universities: Honoring the past, engaging the present, touching the future. The Journal of Negro Education, 76(3), 263-280.

Allison, P.D. (2001). Missing Data. Sage University Papers Series on Quantitative Applications in the Social Sciences, 07-136. Sage Publications.

Anderson, J. D. (1988). The education of Blacks in the South, 1860-1935. University of North Carolina Press.

Astin, A. W., \& Oseguera, L. (2005). The declining "equity" of American higher education. The Review of Higher Education, 27(3), 321-341.

Aud, S., Hussar, W., Kena, G., Bianco, K., Frohlich, L., Kemp, J., \& Tahan, K. (2011). The Condition of Education 2011 (NCES 2011-033). U.S. Department of Education, National Center for Education Statistics. https://nces.ed.gov/pubs2011/2011033.pdf

Avery, C., Hoxby, C. M. (2004). Do and should financial aid packages affect students' college choice? In C. M. Hoxby (Ed.) College Choices: The Economics of Where to Go, When to Go, and How to Pay for It (pp. 239-299). University of Chicago Press.

Babbie, E. R. (2013). The basics of social research. Cengage Learning.

Baker, T. L., \& Vélez, W. (1996). Access to and opportunity in postsecondary education in the United States: A review. Sociology of Education, 69(extra issue), 82-101.

Bandura, A. (1989). Human agency in social cognitive theory. American Psychologist, 44(9), 1175-1184.

Baum, S., \& Ma, J. (2013). Trends in Higher Education 2013. College Board.

Becker, G. S. (1960). Underinvestment in college education? The American Economic Review, 50(2), 346-354. 
Becker, G. S. (1962). Investment in human capital: a theoretical analysis. The Journal of Political Economy, 70(5), 9-49.

Belley, P., \& Lochner, L. (2007). The changing role of family income and ability in determining educational achievement. Journal of Human Capital, 1(1), 37-89. https://doi.org/10.1086/524674

Bennett, P. R., \& Lutz, A. (2009). How African American is the net black advantage?: Differences in college enrollment among immigrant blacks, native blacks and whites. Sociology of Education, 82(1). 70-100. https://doi.org/10.1177/003804070908200104

Bigg, M. (2009). Recession hits Black colleges hard. Reuters. http://www.reuters.com/article/us-usa-universities-blackidUSTRE51F00B20090216

Billingsley, A. (1992). Climbing Jacob's Ladder: The enduring legacy of AfricanAmerican families. Oxford University Press.

Bourdieu, P. (1986). The forms of capital. In J. G. Richardson (Ed.), Handbook of Theory and Research for the Sociology of Education (pp. 241-258). Greenwood Publishing Group.

Bourdieu, P., \& Passeron, J.-C. (1977). Reproduction in education, culture and society.Sage Publications.

Bourdieu, P., \& Passeron, J.-C. (1990). Reproduction in education, society and culture: Second edition. Translated by R. Nice. Sage Publications.

Bowen, W. G., \& Bok, D. (1998). The shape of the river. Princeton University Press. https://doi.org/10.1515/9781400882793

Bowles, F., \& DeCosta, F. A. (1971). Between two worlds: a profile of Negro higher education. : McGraw-Hill.

Boyle, R. P. (1966). The effect of the high school on students' aspirations. American Journal of Sociology, 17(6), 628-639.

Bradshaw, G., Espinoza, S., \& Hausman, C. (2001). The college decision-making of high achieving students. College and University, 77(2), 15-22.

Brantley-Jones, K (2020, July 31). 6 historically Black colleges receive millions in record donations from Mackenzie Scott, Amazon boss Jeff Bezos' ex-wife. https://abcnews.go.com/US/black-colleges-receive-millions-record-donationsmackenzie-scott/story?id=72068091

Braxton, J. M. (1990). How students choose colleges. In D. Hossler, J. Bean (Eds.) The strategic management of college enrollments (pp. 57-67). Jossey-Bass. 
Brown II, M. C., \& Ricard, R. B. (2007). The honorable past and uncertain future of the nation's HBCUs. Thought \& Action (Fall 2007),117-130.

Brown, M., \& Freeman, K. (2002). Research on historically black colleges. The Review of Higher Education, 25(3), 237-368.

Brown, M. C., \& Davis, J. E., (2001). The historically Black college as social contract, social capital, and social equalizer. Peabody Journal of Education, 76(1), 31-49.

Brown, M. C., Donahoo, S., \& Bertrand, R. D. (2001). The Black college and the quest for educational opportunity. Urban Education, 36(5), 553-571.

Brown, M. C., \& Freeman, K. (Eds.). (2004). Black colleges: New perspectives on policy and practice. Praeger.

Browning, J., \& Williams, J. B. (1978). History and goals of Black institutions of higher learning. Black colleges in America, 68-93.

Bureau of Labor Statistics, U.S. Department of Labor (2016). The Economics Daily: Volunteer rate down slightly for the year ending in September 2015. https://www.bls.gov/opub/ted/2016/volunteer-rate-down-slightly-for-theyear-ending-in-september-2015.htm

Cabrera, A. F., \& La Nasa, S. M. (2001). On the path to college: three critical tasks facing America's disadvantaged. Research in Higher Education, 42(2), 119-149.

Carnevale, A. P., Smith, N., \& Strohl, J. (2010). Help wanted: Projections of job and education requirements through 2018.

https://repository.library.georgetown.edu/bitstream/handle/10822/559303/FullRep ort.pdf?sequence $=1$

Catsiapis, G. (1987). A model of educational investment decisions. The Review of Economics and Statistics, 69(1), 33-41. https://doi.org/10.2307/1937898

Ceja, M. (2006). Understanding the role of parents and siblings as information sources in the college choice process of Chicana students. Journal of College Student Development, 47(1), 87-104.

Chapman, D. W. (1981). A model of student college choice. The Journal of Higher Education, 52(5), 490-505. https://doi.org/10.1080/00221546.1981.11778120

Coleman, J. S. (1988). Social capital in the creation of human capital. American Journal of Sociology, 94(Supplement). S95-S120.

Creswell, J. W. (2009). The selection of a research design. Research design: qualitative, quantitative and mixed methods approaches. Sage Publications. 
Cuyjet, M. J. (1997). African American men on college campuses: Their needs and their perceptions. New Directions for Student Services, (Winter, No. 80), 5-16. https://doi.org/10.1002/ss.8000

de Brey, C., Musu, L., McFarland, J., Wilkinson-Flicker, S., Diliberti, M., Zhang, A., Branstetter, C., \&nd Wang, X. (2019). Status and Trends in the Education of Racial and Ethnic Groups 2018 (NCES 2019-038). U.S. Department of Education. National Center for Education Statistics.

DesJardins, S. L., Ahlburg, D. A., \& McCall, B. P. (2006). An integrated model of application, admission, enrollment, and financial aid. Journal of Higher Education, 77(3), 381-429.

DesJardins, S.L., and Toutkoushian, R. K. (2005). Are students really rational? The development of rational thought and its application to student choice. In J.C. Smart (ed.), Higher education: Handbook of theory and research, Vol. 20, (pp. 191-240). Kluwer Academic Publishers.

Dewan, S. (2009, February 18). Economy hits hard on black campuses. The New York Times. https://www.nytimes.com/2009/02/19/us/19colleges.html

DiMaggio, P., \& Mohr, J. (1985). Cultural capital, educational attainment, and marital selection. American Journal of Sociology, 90(6), 1231-1261. https://doi.org/10.1086/22820

Drewry, H. N., Doermann, H., \& Anderson, S. H. (2001). Stand and prosper: Private Black colleges and their students: Princeton University Press.

Duncan, A. D. (2013). Sistahs with voices: influences that affected the college choice of high-achieving African American women who chose to attend a predominantly white institution instead of an historically black college or university. (Ph.D. dissertation), University of Louisville. http://dx.doi.org/10.18297/etd/384

Durkheim, E. (1956). Education and Sociology. Free Press.

Eagan, K., Stolzenberg, E. B., Bates, A. K., Aragon, M. C., Suchard, M. R., \& RiosAguilar, C. (2015). The American freshman: National norms fall 2015. Higher Education Research Institute, UCLA.

Ellwood, D., \& Kane, T. J. (2000). Who is getting a college education: family background and the growing gaps in enrollment. In S. Danziger \& J. Waldfogel (Eds.), Securing the future: investing in children from birth to college (pp. 283324). Russell Sage Foundation.

Epps, E. G. (1972). Higher education and Black Americans: Implications for the future. In E. G. Epps (Ed.), Black students in White Schools (pp. 102-111). Charles A. Jones Publishing. 
Fleming. J. (1984). Blacks in college (1 $1^{\text {st }}$ ed.) Jossey-Bass.

Flowers, L. A. (2002). The impact of college racial composition on African American students' academic and social gains: additional evidence. Journal of College Student Development, 43(3), 403-410.

Fostering Undergraduate Talent by Unlocking Resources for Education (FUTURE) Act (2019). https://www.congress.gov/bill/116th-congress/house-bill/5363

Franklin, V. P. (2000). Cultural capital and Black education: African American communities and the funding of Black schooling, 1860 to the Present. Information Age Publishing.

Freeman, K. (1997). Increasing African Americans' participation in higher education: African American high-school students' perspectives. Journal of Higher Education, 68(5), 523-550. https://doi.org/10.2307/2959945

Freeman, K. (1999a). HBCs or PWIs? African American high school students' consideration of higher education institution types. The Review of Higher Education, 23(1), 91-106.

Freeman, K. (1999b). The race factor in African Americans' college choice. Urban Education, 34(1), 4-25. https://doi.org/10.1177/0042085999341002

Freeman, K. (2005). African Americans and college choice: the influence of family and school. State University of New York Press.

Freeman, K., \& Thomas, G. E. (2002). Black colleges and college choice: Characteristics of students who choose HBCUs. The Review of Higher Education, 25(3), 349358. https://doi.org/10.1353/rhe.2002.0011

Fry, R. (2002). Latinos in higher education: Many enroll, too few graduate. Pew Hispanic Center. https://files.eric.ed.gov/fulltext/ED468848.pdf

Garcia, E. (2014). The effects of cultural and social capital on college choice: An examination of the differences between Latino students and their racial/ethnic peers. (Doctor of Higher Education Administration Dissertation, Seton Hall University. https://scholarship.shu.edu/cgi/viewcontent.cgi?article=2996\&context=dissertatio ns

Gasman, M. (2006). Salvaging "academic disaster areas": The Black college response to Christopher Jencks and David Riesman's 1967 Harvard Educational Review article. The Journal of Higher Education, 77(2), 317-352. https://doi.org/10.1080/00221546.2006.11778928 
Gasman, M., Baez, B., Drezner, N. D., Sedgwick, K. V., Tudico, C., \& Schmid, J. M. (2007). Historically Black colleges and universities: Recent trends. Academe, 93(1), 69-77.

Gasman, M., Lundy-Wagner, V., Ransom, T., \& Bowman III, N. (2010). Special issue: Unearthing promise and potential--Our nation's historically Black colleges and universities. ASHE Higher Education Report, 35(5), 1-134.

Gaynor, G. K. (2014). HBCU enrollments on the decline, will they ever recover? Retrieved from http://www.centrictv.com/news-views/raceculture/articles/2014/02/05/hbcu-enrollments-on-the-decline-will-they-everrecover.html

Gelo, O., Braakmann, D., \& Benetka, G. (2008). Quantitative and qualitative research: Beyond the debate. Integrative psychological and behavioral science, 42(3), 266290.

Gladiuex, L., \& Swail, W. S. (2008). Financial aid is not enough: Improving the odds for minority and low-income students: In J. E. King (Ed.), Financing a college education: how it works, how it's changing (pp. 177-197). Oryx Press.

Goldin, C., Katz, L. F., \& Kuziemko, I. (2006). The homecoming of American college women: The reversal of the college gender gap. The Journal of Economic Perspectives, 20(4), 133-156.

Grubb, W. N. (2002). Learning and earning in the middle, part 1: National studies of prebaccalaureate education. Economics of Education Review, 21(4), 299-321.

Hanson, K.N., \& Litten, L. H. (1989). Mapping the road to academe: a review of research on women, men, and the college selection process. In P.J Pervin (Ed), The undergraduate women: Issues in educational equity, (pp. 73-98). Lexington Books.

Harper, S. R., Patton, L. D., \& Wooden, O. S. (2009). Access and equity for African American students in higher education: A critical race historical analysis of policy efforts. The Journal of Higher Education, 80(4), 389-414.

Hauptman, A., \& Smith, P. (1994). Financial aid strategies for improving minority student participation in higher education. In M. J. Justiz, R. Wilson, \& L. G. Bjork (Eds.), Minorities in higher education (pp. 78-106). American Council on Education, Oryx Press.

Hearn, J. C. (1984). The relative roles of academic, ascribed, and socioeconomic characteristics in college destinations. Sociology of Education, 57(1), 22-30.

Hearn, J. C. (1988). Attendance at higher-cost colleges: Ascribed, socioeconomic, and academic influences on student enrollment patterns. Economics of Education Review, 7(1), 65-76. 
Hearn, J. C. (1991). Academic and nonacademic influences on the college destinations of 1980 high school graduates. Sociology of Education, 64(3), 158-171.

Hearn, J. C., \& Anderson, M. S. (1995). The Minnesota financing experiment. New Directions for Higher Education, 1995(89), 5-25. https://doi.org/10.1002/he.36919958903

Hedgepeth Jr, C. M., Edmonds, R. R., \& Craig, A. (1978). History and purpose: Overview. In C. V. Willie \& R. R. Edmonds (Eds.), Black colleges in America: Challenges, development, survival (pp. 97-99). Teachers College Press.

Heller, D. E. (1997). Student price response in higher education: An update to Leslie and Brinkman. The Journal of Higher Education, 68(6), 624-659. https://doi.org/10.1080/00221546.1997.11779004

Heller, D. E. (1999). The effects of tuition and state financial aid on public college enrollment. The Review of Higher Education, 23(1), 65-89. https://doi.org/10.1353/rhe.1999.0023

Hirt, J. B., Strayhorn, T. L., Amelink, C. T., \& Bennett, B. R. (2006). The nature of student affairs work at historically Black colleges and universities. Journal of College Student Development, 47(6), 661-676.

Hoffman, K., Llagas, C., \& Snyder, T. D. (2003). Status and trends in the education of Blacks. Washington, DC: U.S. Department of Education. http://files.eric.ed.gov/fulltext/ED-481811.pdf

Horvat, E. M. (2001). Understanding equity and access in higher education: the potential contribution of Pierre Bourdieu. In J. C. Smart (Ed.), Higher education: handbook of theory and research, Vol. XVI (pp. 195-238). Agathon Press.

Hossler, D., Braxton, J., \& Coopersmith, G. (1989). Understanding student college choice. In M. B. Paulsen \& J. C. Smart (Eds.), Higher education: handbook of theory and research, Vol. V (pp. 231-288). Agathon Press.

Hossler, D., \& Gallagher, K. S. (1987). Studying student college choice: a three-phase model and the implications for policymakers. College and university, 62(3), 207221.

Hossler, D., \& Palmer, M. (2012). Why understand research on college choice? In T. Hatch \& R. Bardwell (Eds.), National Association for College Admission Counseling, NACAC's fundamentals of college admission counseling ( $2^{\text {nd }}$ ed., pp. 42-53). Kendall Hunt Publishing.

Hossler, D., Schmit, J., \& Vesper, N. (1998). Going to college: how social, economic, and educational factors influence the decisions students make. Johns Hopkins University Press. 
Hossler, D., \& Stage, F. K. (1992). Family and high school experience influences on the postsecondary educational plans of ninth-grade students. American Educational Research Journal, 29(2), 425-451.

Hu, S., \& Hossler, D. (2000). Willingness to pay and preference for private institutions. Research in Higher Education, 41(6), 685-701.

Huck, S.W. (2000) Reading statistics and research, $3^{\text {rd }}$ ed., Addison Wesley Longman Inc.

Hurtado, S., Inkelas, K. K., Briggs, C., \& Rhee, B.-S. (1997). Differences in college access and choice among racial/ethnic groups: Identifying continuing barriers. Research in Higher Education, 38(1), 43-75.

Irvine, J. J., (1990). Black students and school failure. Policies, practices, and prescriptions. Greenwood Press.

Jackson, G. A. (1990). Financial aid, college entry, and affirmative action. American Journal of Education, 98(4), 523-550.

Jacob, B. A. (2002). Where the boys aren't: Non-cognitive skills, returns to school and the gender gap in higher education. Economics of Education Review, 21(6), 589598.

Jencks, C., \& Riesman, D. (1967a). The American Negro college. Harvard Educational Review, 37(2), 3-60.

Jencks, C., \& Reisman, D. (1967b). Four Responses and a Reply. Harvard Educational Review, 37(3), 465-468.

Johnson, R. G., Stewart, N. R., \& Eberly, C. G. (1991). Counselor impact on college choice. The School Counselor, 39(2), 84-90.

Johnson, R. H., \& Chapman, D. W. (1979). An assessment of college recruitment literature: Does the high school senior understand it? Research in Higher Education, 11(4), 309-319.

Kane, T. J. (2004). College-going and inequality: A literature review. In K. Neckerman (Ed.), Social inequality (pp. 319-354). Russell Sage Foundation.

Kane, T. J. (2010). The price of admission: Rethinking how Americans pay for college. Brookings Institution Press.

Kannerstein, G. (1978). Black colleges: Self-concept. In C. V. Willie \& R. R. Edmonds (Eds.), Black colleges in America (pp. 29-50). Teachers College Press.

Kao, G. \& Tienda, M. A. (1998). Educational aspirations of minority youth. American Journal of Education, 106(3), 349-384. 
Keane, M. P., \& Wolpin, K. I. (2001). The effect of parental transfer and borrowing constraints on educational attainment. International Economic Review, 42(4), 1051-1103.

Kena, G., Musu-Gillette, L., Robinson, J., Wang, X., Rathbun, A., Zhang, J., WilkinsonFlicker, S., Barmer, A., \& Dunlop Velez, E. (2015). The Condition of Education 2015 (NCES 2015-144). U.S. Department of Education, National Center for Education Statistics. https://nces.ed.gov/pubs2015/2015144.pdf

Kim, M. M., \& Conrad, C. F. (2006). The impact of historically Black colleges and universities on the academiic success of African American students. Research in Higher Education, 47(4) 399-427

Kim, D. (2004). The effect of financial aid on students' college choice: Differences by racial groups. Research in Higher Education, 45(1), 43-70.

Kim, J., DesJardins, S. L., \& McCall, B. P. (2009). Exploring the effects of student expectations about financial aid on postsecondary choice: A focus on income and racial/ethnic differences. Research in Higher Education, 50(8), 73-85.

Klevorick, A. K. (1975). Law and economic theory: An economist's view. The American Economic Review, 65(2), 237-243.

Lareau, A. (1987). Social class differences in family-school relationships: The importance of cultural capital. Sociology of Education, 60(2), 73-85.

Leslie, L. L., \& Brinkman, P. T. (1998). The economic value of higher education. American Council on Education, MacMillan.

Lin, D., Foster, D.P., \& Ungar, L.H. (2011). VIF Regression: A fast regression algorithm for large data. Journal of the American Statistical Association, 106(493), 232-247. https://doi.org/10.1198/jasa.2011.tm10113

Lin, N. (2000). Inequality in social capital. Contemporary Sociology, 29(6), 785-795.

Litten, L. H. (1982). Different strokes in the applicant pool: some refinements in a model of student college choice. The Journal of Higher Education, 53(4), 383-402.

Ma, J., Pender, M., \& Welch, M. . Education pays 2016: The benefits of higher education for individuals and society. The College Board.

Manski, C. F., \& Wise, D. A. (1983). College choice in America. Harvard University Press.

Mayhew, M. J., Rockenbach, A. N., Bowman, N. A., Seifert, T. A. D., \& Wolniak, G. C. (2016). $21^{\text {st }}$ century evidence that higher education works. Jossey-Bass. 
McDonough, P. M. (1997). Choosing colleges: how social class and schools structure opportunity. SUNY Press.

McDonough, P. M. (2004). The school-to-college transition: challenges and prospects. American Council on Education, Center for Policy Analysis.

McDonough, P. M., Antonio, A. L., \& Trent, J. W. (1997). Black students, Black colleges: an African American college choice model. Journal for a Just and Caring Education, 3(1), 9-36.

McFarland, J., Hussar, B., Zhang, J., Wang, X., Wang, K., Hein, S., Diliberti, M., Forrest Cataldi, E., Bullock Mann, F., \& Barmer, A. (2019). The Condition of Education 2019 (NCES 2019-144). U.S. Department of Education. National Center for Education Statistics. https://nces.ed.gov/pubs2019/2019144.pdf

Menard, C. (1995). Applied logistic regression analysis. Sage Publications.

Miles, J. \& Shelvin, M. (2001). Applying regression and correlation: A guide for students and researchers, Sage Publications.

Mintz, S. (2004). Huck's Raft. Belknap Press.

Mullins, D. (2013, October 22). Historically Black colleges in financial fight for their future. http://america.aljazeera.com/articles/2013/10/22/historicallyblackcollegesfightfortheirfuture.html

National Center for Education Statistics (2016). Annual Earnings of Young Adults. http://nces.ed.gov/programs/coe/indicator_cba.asp

National Center for Education Statistics (2019). Number of degree-seeking undergraduate students enrolled in postsecondary institutions for the first-time in the fall (limited by Historically Black College or University) https://nces.ed.gov/ipeds/TrendGenerator/app/answer/2/5?f=59\%3D1

Nettles, M. (Ed.) (1988). Toward Black undergraduate student equity in American higher education. Greenwood Press.

Nora, A. (2004). The role of habitus and cultural capital in choosing a college, transitioning from high school to higher education, and persisting in college among minority and non-minority students. Journal of Hispanic Higher Education, 3(2), 180-208.

Norwood, M. C. (2009). An examination of factors influencing African-American students' choice to attend predominately White colleges and universities. ( $\mathrm{PhD}$ Dissertation), Auburn University. 
Owen, A. (2017). Income segregation between school districts and inequality in students' achievements. Sociology of Education, 91(1), 1-27.

https://doi.org/10.1177/0038040717741180

Palmer, R., \& Gasman, M. (2008). "It takes a village to raise a child": The role of social capital in promoting academic success for African American men at a Black college. Journal of College Student Development, 49(1), 52-70.

Pampel, F. (2000). Logistic Regression: A Primer. Sage Publications.

Paulsen, M. B. (1998). Recent research on the economics of attending college: Returns on investment and responsiveness to price. Research in Higher Education, 39(4), 471-489.

Paulsen, M. B. (2001). The economics of human capital and investment in higher education. In M. B. Paulsen \& J. C. Smart (Eds.), The finance of higher education: theory, research, policy \& practice (pp. 55-94). Agathon Press.

Paulsen, M. B., \& St. John, E. P. (2002). Social class and college costs: examining the financial nexus between college choice and persistence. The Journal of Higher Education, 73(2), 189-236.

Pelavin, S. H., \& Kane, M. B. (1990). Changing the odds: factors increasing access to college. College Entrance Examination Board.

Peng, C.Y., Lee, K. L., \& Ingersoll, G. M. (2002). An introduction to logistic regression analysis and reporting. The Journal of Educational Research, 96, 3-14.

Perez, P. A., \& McDonough, P. M. (2008). Understanding Latina and Latino college choice: A social capital and chain migration analysis. Journal of Hispanic Higher Education, 20(10), 17. https://doi.org/10.1177/1538192708317620

Perna, L. W. (2000). Racial/ethnic group differences in the realization of educational plans. Paper presented at the annual meeting of the Americal Educational Research Association New Orleans, LA. https://repository.upenn.edu/gse_pubs/318/

Perna, L. W. (2005). The key to college access: A college preparatory curriculum. In W. G. Tierney, Z. B. Corwin, \& J. E. Colyar (Eds.), Preparing for college: Nine elements of effective outreach. SUNY Press.

Perna, L. W. (2006). Studying college access and choice: A proposed conceptual model. In J. C. Smart (Ed.), Higher education: handbook of theory and research, Vol. 21 (pp. 99-157). Springer.

Perna L. W. \& Titus, M. A. (2004). Understanding differences in the choice of college attended: the role of state public policies. The Review of Higher Education, 27(4), 501-525. 
Perna, L. W., Steele, P., Woda, S. \& Hibbert, T. (2005). State public policies and the racial/ethnic stratification of college access and choice in the state of Maryland. The Review of Higher Education, 28(2), 245-272. https://doi.org/10.1353/rhe.2004.0037

Perna, L. W., \& Titus, M. A. (2005). The relationship between parental involvement as social capital and college enrollment: An examination of racial/ethnic group differences. Journal of Higher Education, 76(5), 485-518.

Pitre, P. E. (2006). College choice: A study of African American and White student aspirations and perceptions related to college attendance. College Student Journal, 40(3), 562.

Planty, M., Hussar, W. J., \& Snyder, T. D. (2009). Condition of education 2009. U.S. Department of Education.

Redd, K. E. (1998). Historically Black colleges and universities: Making a comeback. New Directions for Higher Education, 1998(102), 33-43.

Richards, D. A. R., \& Awokoya, J. T. (2012). Understanding HBCUs: Retention and completion. Frederick D. Patterson Research Institute, United Negro College Fund.

Roebuck, J. B., \& Murty, K. S. (1993). Historically Black colleges and universities: Their place in American higher education. Praeger.

Rouse, C. E. (1994). What to do after high school: The two-year versus four-year college enrollment decision. In R.G. Ehrenberg (ed.) Choices and consequences: Contemporary policy issues in education (pp.59-88). IRL Press.

Samuels, A. L. (2004). Is separate unequal?: Black colleges and the challenge to desegregation. University Press of Kansas.

Semega, J. L., Fontenot, K. R., \& Kollar, M. A. (2017). Income and Poverty in the United States: Current population report, pp. 60-259. U.S. Department of Commerce.

Sewell, W. H., Hauser, R. M., \& Wolf, W. C. (1980). Sex schooling and occupational status. American Journal of Sociology, 551-583

Sewell, W. H., \& Shah, V. P. (1967). Socioeconomic status, intelligence, and the attainment of higher education. Sociology of Education, 40(1), 1-23.

Shankle, N. M. (2009). African Americans and college-choice: Case studies of four families. University of Cincinnati.

Sink, J. D. (1995). Public policy and America's land-grant educational enterprise: The unique West Virginia experience. Journal of Negro Education, 64(1), 6-14. 
Sissoko, M., \& Shiau, L.-R. (2005). Minority enrollment demand for higher education at historically Black colleges and universities from 1976 to 1998: An empirical analysis. The Journal of Higher Education, 76(2), 181-208.

Smith, M. J., \& Fleming, M. K. (2006). African American parents in the search stage of college choice: Unintentional contributions to the female to male college enrollment gap. Urban Education, 41(1), 71-100.

Solorzano, D., Ceja, M., \& Yosso, T. (2000). Critical race theory, racial microaggressions, and campus racial climate: the experiences of African American college students. Journal of Negro Education, 69(1/2), 60-73.

Snyder, T.D. (2018) Mobile Digest of Education Statistics, 2017. NCES 2018-138. U.S. Department of Education, National Center for Education Statistics.

Steven, J. P. (2009) Applied Multivariate Statistics for Social Socience. Fifth Edition, Routledge Taylor \& Francis Group.

St. John, E. P. (2003). Refinancing the college dream. Johns Hopkins University Press.

St. John, E.P. (2002). The access challenge: Rethinking the causes of the new inequality (Policy Issue Report \# 2002-01). Indiana Education Policy Center,

St. John, E. P. (1991). What really influences minority attendance? Sequential analyses of the high school and beyond sophomore cohort. Research in Higher Education, 32, 141-158. https://doi.org/10.1007/BF00974434

St. John, E. P., Asker, E. H., \& Hu, S. (2001). The role of finances in student choice: a review of theory and research. In M. B.Paulsen \& J. C. Smart (Eds.), The finance of higher education: theory, research, policy \& practice (pp. 419-438). Agathon Press.

St. John, E. P., \& Noell, J. (1989). The effects of student financial aid on access to higher education: an analysis of progress with special consideration of minority enrollment. Research in Higher Education, 30, 563-581. doi: 10.1007/BF00992391

St. John, E. P., Paulsen, M. B., \& Carter, D. F. (2005). Diversity, college costs, and postsecondary opportunity: An examination of the financial nexus between college choice and persistence for African Americans and Whites. Journal of Higher Education, 76(5), 545-569. https://doi.org/10.1353/jhe.2005.0035

Stanton-Salazar, R. D. (1997). A social capital framework for understanding the socialization of racial minority children and youth. Harvard Educational Review, 67(1), 1-41. 
Stage, F. K., Hossler, D. (1989). Differences in family influences on college attendance plans for male and female ninth graders. Research in Higher Education, 30(3), 301-315.

Stewart, G., Wright, D., Perry, T., \& Rankin, C. (2008). Historically Black colleges and universities: Caretakers of precious treasure. Journal of College Admission (201), 24-29.

Strayhorn, T. L. (2008). The role of supportive relationships in facilitating African American males' success in college. Naspa Journal, 45(1), 26-48.

Strayhorn, T. L., \& Terrell, M. C. (2010). The evolving challenges of black college students: new insights for policy, practice, and research. Stylus Publishing.

Swail, W. S., Redd, K. E., \& Perna, L. W. (2003). Retaining minority students in higher education: A framework for success. ASHE-Eric Higher Education Report. Jossey-Bass.

Terenzini, P. T., Cabrera, A. F., \& Bernal, E. M. (2001). Swimming against the tide: The poor in American higher education. Research report no. 2001-1. College Entrance Examination Board. http://files.eric.ed.gov/fulltext/ED562879.pdf

Tierney, W. G., \& Venegas, K. M. (2006). Fictive Kin and social capital: The role of peer groups in applying and paying for college. American Behavioral Scientist, 49 (12), 168-170.

Valadez, J. R. (1998). Applying to college: Race, class, and gender differences. Professional School Counseling, 1(5), 14-20.

Van Camp, D., Barden, J., Sloan, L. R., \& Clarke, R. P. (2009). Choosing an HBCU: An opportunity to pursue racial self-development. The Journal of Negro Education, 78(4), 457-468.

Vogt, W. (1999). Dictionary of Statistics and Methodology. $2^{\text {nd }}$ Ed.: Sage publications.

Walpole, M. (2008). Emerging from the pipeline; African American students, socioeconomic status, and college experiences and outcomes. Research in Higher Education, 49 (3): 237-255.

Walters, R. (1991). A cultural strategy for the survival of historically Black colleges and universities. Paper presented at the Annual Conference of the National Council for Black Studies, Atlanta, GA.

Warner, R. M. (2013). Applied Statistics: From Bivariate Through Multivariate Techniques. Sage Publications.

Williams, M. W. (Ed.) (1993). The African American encyclopedia (Vol. 3). Marshall Cavendish Corp. 
Willie, C. V., \& Reddick, R. J. (2010). A new look at Black families. Rowman \& Littlefield Publishers.

Wilson, R. (1994). The participation of Americans in American Higher Education. Minorities in Higher Education (pp.195-209). Oryx Press.

Winkle-Wagner, R. (2015). Having their lives narrowed down? The state of Black women's college success. Review of Educational Research, 85(2), 171-204. 


\section{Appendix A: 2015 CIRP The Freshman Survey (TFS)}

\section{CIRP Freshman Survey}

PLEASE PRINT IN ALL CAPS YOUR NAME AND PERMANENT/HOME ADDRESS (one letter or number per box). NAME:

$$
\text { RST }
$$$$
\text { MI LAST }
$$

ADDRESS:

CITY: STUDENT ID\# (as instructed):

PHONE:

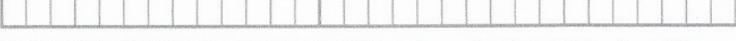

\begin{tabular}{|l|l} 
MARKING DIRECTIONS \\
- Use a black or blue pen. \\
• Fill in your response completely. \\
Mark out any answer you wish to \\
change with an " $\mathrm{X}$ ". \\
CORRECT MARK INCORRECT MARKS \\
Group Code
\end{tabular}

From what kind of high school did you graduate? (Mark one)

Public school (not charter or magnet)

Public charter school

Public magnet schoo

Private religious/parochial school

Private independent college-prep schoo

$$
\text { Home school }
$$

10. Prior to this term, have you ever taken courses for credit at this institution? Yes No

1. Your sex: $\bigcirc$ Male $\bigcirc$ Female 2. How old will you be on December 31 of this year? (Mark one) 16 or younger. $21-24 \ldots . .$. 17.................... $\bigcirc 25-29 \ldots \ldots \ldots$ 18....................

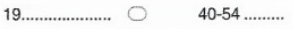

20.................. $\bigcirc 5$ or older.

3. Is English your native language? Yes No

4. In what year did you graduate from 2015.......... Did not graduate bu 2014........... passed G.E.D. test. 2013.......... Never completed 2012 or earlier 1 high school....

5. Are you enrolled (or enrolling) as a: (Mark one) Full-time student... Part-time student.......

6. How many miles is this college from your permanent home? (Mark one) 5 or less $\quad 11-50 \bigcirc \quad 101-500$ 6-10 51-100 Over 500

7. What was your average grade in high school? (Mark one)

$A$ or $A+O$ B

$$
\begin{array}{ll}
\mathrm{A}-\mathrm{O} & \mathrm{B}-\mathrm{O} \\
\mathrm{B}+\mathrm{O} & \mathrm{C}+\mathrm{O}
\end{array}
$$

8. What were your scores on the SAT and/or ACT?

SAT Critical Reading.....

SAT Mathematics

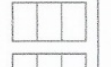

11. Since leaving high school, have you ever taken courses, whether for credit or not for credit, at any other institution (university, 4 or 2 -year college, technica, Yes No

12. Where do you plan to live during the fall term? (Mark one)

With my family or other relatives Other private home, apartment, or room. College residence hall.

Fraternity or sorority house Other campus student Other.

13. To how many colleges other than this on did you apply for admission this year? None $1 \bigcirc 40 \quad 7-8$

$\bigcirc \quad 2 \bigcirc \quad 5 \bigcirc \quad 9-10 \bigcirc$
$3 \bigcirc 6$ 11 or more 14. Were you accepted by your first choice college? Yes No

15. Is this college your: (Mark one) First choice ............ $\bigcirc$ Less than third Second choice........ choice ........... Third choice............

16. Citizenship status: (Mark one) U.S. citizen

Permanent resident (green card)

International student ( $\mathrm{F}-1$ or $\mathrm{M}-1$ visa) None of the above

17. Please mark which of the following courses you have completed:

(1) (D) Algebra II

(4) (14) Pre-calculus/Trigonometry

(8) (11) Probability \& Statistics

(1) (i) Calculus

SAT Writing

(1) (1) AP Probability \& Statistics

(1) (1) AP Calculus
18. How many weeks this summer did you participate in a bridge program at this institution?

$0 \begin{array}{lllll}0 & 0 & 0 & 7+\end{array}$ (-2 5-6 19. Have you had, or do you feel you will need, any
special tutoring or remedial work in any of the following subjects? (Mark all that apply)

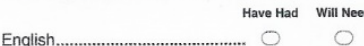
Mathematics

Social Studies.

Science.

Foreign Language

Writing.

20. How many Advanced Placement/International Baccalaureate courses or exams did you take in high school? (Mark one for each row)

AP Courses . . 000000 AP Exams............................ 000000 IB Courses......................... 000000 IB Exams ............................ 000000

21. At this institution, which course placement tests have you taken in the following subject areas: (1) (10) English (1) (11) Reading

(4) (11) Mathematics

(1) (11) Writing

22. Please mark the sex of your parent(s) or guardian(s).

ParentGuardian 1 Parent/Guardian 2

23. Are your parents: (Mark one) Both alive and living with each other......... Both alive, divorced or living apart............. One or both deceased

24. Do you consider yourself: (Mark Yes or No for each item) Yes No 00

..............

25. Please indicate your intended majo

attached fold out.

ACT Composite

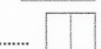




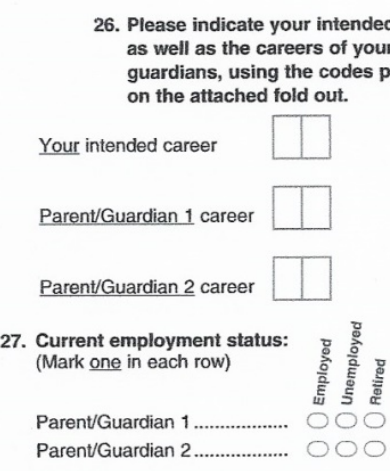

28. How much of your first year's educational expenses (room, board, tuition, and fees) do you expect to cover from each of the sources listed below? (Mark one answer for each possible source)

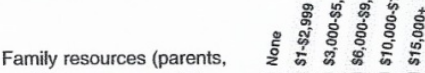
relatives, spouse, etc.) ....... $\bigcirc 00000$

My own resources (savings

from work, work-study,

other income).

Aid which need not be repaid

(grants, scholarships,

military funding, etc.) .......... 000000

Aid which must be repaid

(loans, etc.) ...

Other than above

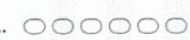

29. Did you receive any of the following forms of financial aid? (Mark Yes or No for each item)

Military grants

Yes No

Work-study

Pell Grant ..

Need-based grants or scholarships.

Merit-based grants or scholarships.

30. What is your best estimate of your parents' guardians' total income last year? Consider income from all sources before taxes. (Mark one)

Less than $\$ 10,000 \bigcirc \$ 50,000-59,999$

$\$ 10,000-14,999 \bigcirc \$ 60,000-74,999$

\$ $\$ 15,000-19,999$

$\$ 75,000-99,999$

$\$ 20,000-24,999$

\$100,000-149,999

\$25,000-29,999

$\$ 150,000-199,999$

\$30,000-39,999

$\$ 200,000-249,999$

(1) $\$ 40,000-49,999$

\$250,000 or mor

31. Do you have any concern about your ability to finance your college education? (Mark one)

None (I am confident that I will have sufficient funds)... Some (but I probably will have enough funds).. Major (not sure I will have enough funds to complete college)

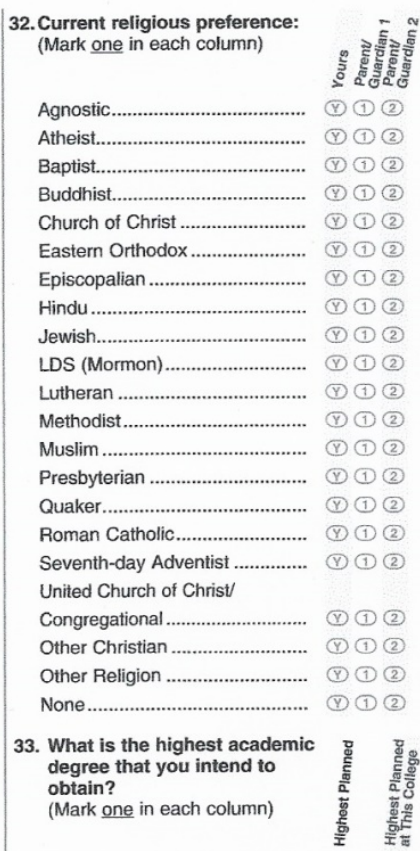

None ... $\bigcirc$... Vocational certificate .................. ... Associate (A.A. or equivalent)... ... Bachelor's degree (B.A., B.S., etc.). ... Master's degree (M.A., M.S., etc.) Ph.D. or Ed.D.

M.D. D.O., D.D.S., or D.V.M. .... B.D. or M.DIV. (Divinity) ............. ...

34. For the activities below, indicate which ones you did during the past year. If you engaged in an activity frequently, mark $(P$. If you engaged in an activity on times, but not frequently, mark (O) (Occasionally). Mark (Ni) (Not at all) if you have not performed at all) if you have not performed year. (Mark one for each item) Attended a religious service ....... (F) () (ㄱ) Was bored in class. (F) (ㅇ) (1) Demonstrated for a cause (e.g.,

boycott, rally, protest)... (ㄷ) (ㅇ) (1) Tutored another student. (F) (2) (N) Studied with other students....... (F) (ㅇ) (N) Smoked cigarettes..................... (F) (2) (N) Drank beer. (ㄷ) (ㅇ) (18) Drank wine or liquor .. () (ㅇ) (1) Felt overwhelmed by all I had to do. (F) (c) (1) Felt depressed. (F) (1) (N) Performed volunteer work .......... (F) (2) (1) Asked a teacher for advice after class.
34. Continued. For the activities below, indicate which ones you did during the past year. (Mark one for each item)

Voted in a student election... (B) () (11) Socialized with someone of another racial/ethnic group. (F) (ㅇ) (11)

Came late to class.

Performed community

service as a part of a class. (F) (ㅇ) (N) Discussed religion ................. (E) (0) (10)

Discussed politics.. (ㄷ) (2) (16)

Worked on a local, state, or

national political campaign. (F) (C) (15)

Skipped school/class............ (F) (2) (10)

Publicly communicated my

opinion about a cause (e.g.,
blog, email, petition).......... (F) (2) (N)

Helped raise money for a

cause or campaign............. (F) (2) (1)

Fell asleep in class............... (B) (0) (1)

Failed to complete homework

on time …………….... (F) (O) (1)

Used an online instructional

website (e.g., Khan

Academy, Coursera)

As assigned for a class.... (F) (C) (N)

To learn something on

(ㄹ) (2) (1)

35. How would you rate

yourself in the following

areas:

(Mark one for each item) के के

Ability to see the world है है

perspective else's

Tolerance of others

with different beliefs. 00000

Openness to having

my own views

Ability to discuss and

negotiate controversia

issues..

Ability to work

cooperatively with
diverse people.......... 0000

Critical thinking skills.. 00000

Ability to manage your

time effectively ........ 00000

36. What is the highest level of formal education obtained by your parents/ guardians?(Mark one in each column)

Junior high/Middle $\begin{gathered}\text { Parentt } \\ \text { Guardlan } 1\end{gathered} \quad \begin{gathered}\text { Parent/ } \\ \text { Guardian 2 }\end{gathered}$ school or less ............... ............ Some high school........... ........... High school graduate .... $\bigcirc$............ Postsecondary school

other than college.........

Some college................. $\bigcirc$............

College degree ................ $\bigcirc$............ $\bigcirc$

Some graduate school .. $\bigcirc$............

Graduate degree ............ $\bigcirc$............ $\bigcirc$ 


\section{How often in the past year did you? (Mark one for each inem)}

Ask questions in class. Support your opinions with a logical argument.

Seek solutions to problems and explain them to others.

Revise your papers to improve your writing

Evaluate the quality or reliability of information you received...

Take a risk because you feel you

have more to gain .

Seek alternative solutions to a problem.

Look up scientific research

articles and resources

Explore topics on your own, even

though it was not required for a

class.

Accept mistakes as part of the

learning process.

Seek feedback on your academic work

38. Are you: (Mark all that apply)

White/Caucasian .

African American/Black

American Indian/Alaska Native

East Asian (e.g., Chinese, Japanese,

Korean, Taiwanese)

Southeast Asian (e.g., Cambodian,

Vietnamese, Hmong, Filipino)

South Asian (e.g., Indian, Pakistani,

Nepalese, Sri Lankan).

Other Asian .

Native Hawaiian/Pacific Islander

Mexican American/Chicano.

Puerto Rican.

Other Latino.

Other

39. How would you characterize your political views? (Mark one)

Far left

Liberal

Middle-of-the-road

Conservative

Far right

40. In deciding to go to college, how important to you was each of the important to you was

? reason)

To be able to get a better job...

To gain a general education and appreciation of ideas.

To make me a more cultured

person

............. (1) (5) (11)

To be able to make more money ..... (v) (5) (iv)

To learn more about things that

interest me

Tocicic career. (V) (S) (N)

To prepare myself for graduate or

professional school

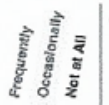

(ㄷ) () (11)

(ㄷ) (2) (11)

(ㄷ) () (ㄴ)

(E) (C) (N)

() () (N)

(D) (C) (N)

(F) (ㅇ) (ii)

(E) (1)

(E) () (11)

(F) (ㄷ) (ㅁ)

(ㄷ) (ㄷ) (10)

$\bigcirc$ 0 . .... $\mathrm{O}$

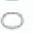
○

atect

(

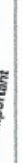

4

\begin{tabular}{|c|c|}
\hline $\begin{array}{l}\text { Rate yourself on each of the following } \\
\text { traits as compared with the average } \\
\text { person your age. We want the most } \\
\text { accurate estimate of how you see } \\
\text { yourself. (Mark one in each row) }\end{array}$ & 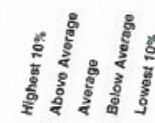 \\
\hline 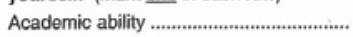 & 00000 \\
\hline Artistic ability & \\
\hline Competitiveness......... & \\
\hline Computer skills..... & \\
\hline Cooperativeness... & 00000 \\
\hline Creativity......................... & 00000 \\
\hline Drive to achieve............. & \\
\hline Emotional health............ & 0 \\
\hline Leadership ab & \\
\hline 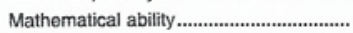 & 00 \\
\hline 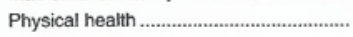 & 00 \\
\hline Public speaking ability.............. & 000 \\
\hline 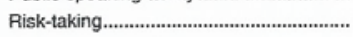 & 00000 \\
\hline Self-confidence (intellectual)...................... & 00000 \\
\hline 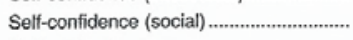 & 0000 \\
\hline 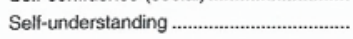 & 00000 \\
\hline 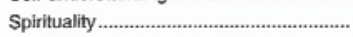 & 00000 \\
\hline 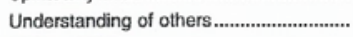 & 00000 \\
\hline 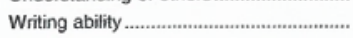 & 0000 \\
\hline
\end{tabular}

2. Mark one in each row:

Racial discrimination is no longer a major problem in America Abortion should be legal.

Colleges have the right to ban extreme speakers from campus

(1) Disagree Strongly (2) Disagree Somewhat (3) Agree Somewhat Realistically, an individual can do little to bring about changes in our society ............ (4) (3) (2) (1) Marijuana should be legalized......................................................................... (4) (3) (2) (1) Dissent is a critical component of the political process............................................ (4) (3) (2) (1) Colleges should prohibit racist/sexist speech on campus......................................... (4) (3) (2) (1) Women should receive the same salary and opportunities for advancement as men in comparable positions The United States should intervene in the wars of other countries ............................. (4) (1) (2) (1) Same-sex couples should have the right to legal marital status................................... (4) (3) (2) (1) Students from disadvantaged social backgrounds should be given preferential treatment in college admissions

Below are some reasons that might have influenced your decision to ttend this particular college. How important was each reason in your decision to come here? (Mark one answer for each possible reason)

My parents/relatives wanted me to come here

My teacher advised me.

This college has a very good academic reputation

The cost of attending this college .................. (v) (s) (1)

High school counselor advised me ........................................................ (iv) (s) (iiv)

Private college counselor advised me..................................................................... (1) (8) (1)

wanted to live near home

Not offered aid by first choice ............................................................................ (v) (5) (Niv)

Could not afford first choice ............................................................................ (1) (8) (1)

This college's graduates gain admission to top graduate/professional schools ... (V) (5) (1)

This college's graduates get good jobs........................................................... (v) (8) (N)

I was attracted by the religious affiliation/orientation of this college ..................... (1) (5) (1)

I wanted to go to a school about the size of this college................................. (v) (3) (1)

Hankings in national magazines ................................................................. (1) (8) (1)

I was admitted through an Early Action or Early Decision program .................... (1) (5) (1)

The athletic department recruited me .......................................................... (1) (5) (1)

A visit to this campus ................................................................................. (8) (8) (1)

The percentage of students that graduate from this college............................... (v) (5) (1) 
44. During your last year in high school, how much time did you spend during a typical week doing the following activities?

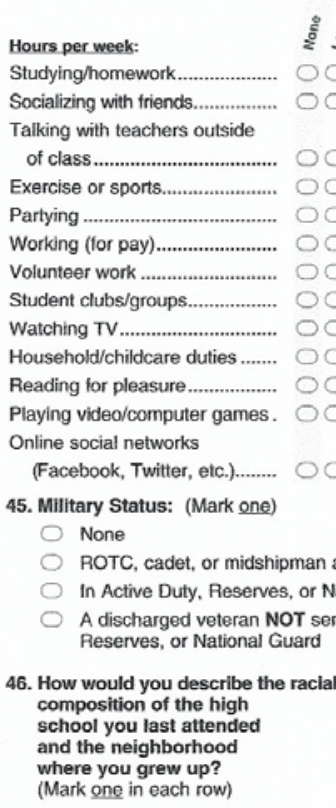<smiles>CC1CC1</smiles>

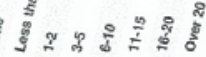
00000000 00000000

\section{0} 00000000 00000000 00000000 00000000 00000000 00000000 00000000 0000000 10000000 an at a service academy National Guard

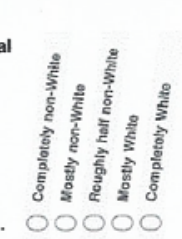
High school 1 last attended............ 00000 Neighborhood where I grew up......... 47. How many years do you exp
graduate from this college?

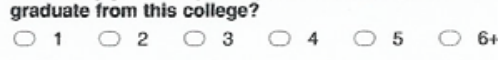
Do not plan to graduate from this college

48. What is your sexual orientation? Heterosexual/Straight

Gay

$\checkmark$ Lesbian

Bisexual

Queer

Other

49. Do you identify as transgender? $\bigcirc$ Yes

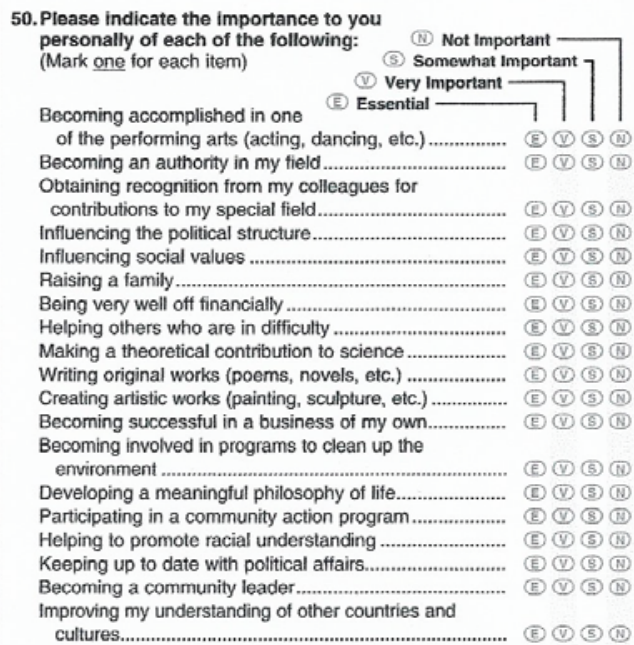

51. What is your best guess as to the chances that you will:

(10) No Chance(L) Very Little Chane Very Good Chance

(v) Very Good Chance-

Change major field (i) (5) (1)

Change career choice ... (1) (S) (L) (1) Participate in student government...................... (v) (S) (D) (1) Get a job to help pay for college expenses................................ (1) (5) (1) (11) Work full-time while attending college......................................... (v) (8) (1) (1) Join a social fraternity or sorority ......................................... (8) (5) (1) (10) Play club, intramural, or recreational sports............................ (v) (5) (1) (10) Play intercollegiate athletics (e.g., NCAA or NAIA-sponsored)... (v) (5) (L) (I) Make at least a "B" average ....................................... (v) (5) (L) (1) Participate in student protests or demonstrations.............. (8) (8) (1) (1) Transfer to another college before graduating Transter to a sto graduating...................... (1) (D) (D) Be Participate in volunteer or community senvice wor Seek personal counseling................................ Communicate regularly with your professors........................... (v) (5) (1) (1) Socialize with someone of another racial/ethnic group.............. (1) (5) (1) (11) Participate in student clubs/groups ........................................... (1) (5) (1) (17) Participate in a study abroad program. Have a roommate of a different race/ethnicity.......................... (1) (5) (D) (1) Discuss course content with students outside of class............. (1) (5) (1) (1) Work on a professor's research project Take courses from more than one college simultaneously Take a leave of absence from this college temporanily............. (v) (S) (D) (iv) Take a leave of absence lron

Take a course exclusivoly ontr

At a different institution .................................................. (v) (8) (1) (1) (1)

The remaining ovals are provided for questions specifically designed by your college rather than the Higher Education Research Institute. If your college has chosen to use the ovals, please observe carefully the supplemental directions given to you.
52. (A) (B) (C) (D) (E)
56. (A) (B) (C) (D) (E)
60. (A) (B) (C) (D) (B)
64. (A) (B) (C) (D) (B)
68. (A) (B) (C) (D) (E)
53. (A) (B) (C) (D) (E)
61. (A) (B) (C) (D) (E)
65. (A) (D) (C) (D) (I)
69. (A) (B) (C) (D) (E)
54. (A) (B) (C) (D) (B)
58. (A) (B) (C) (D) (B)
62. (A) (B) (C) (D) (E)
66. (A) (B) (C) (D) (E)
70. (A) (B) (C) (D) (E)
55. (A) (D) (C) (D) (E)
59. (A) (D) (C) (D) (B)
63. (A) (B) (C) (D) (E)
67. (A) (B) (C) (D) (E)
71. (A) (B) (C) (D) (5)

\section{THANK YOU!}




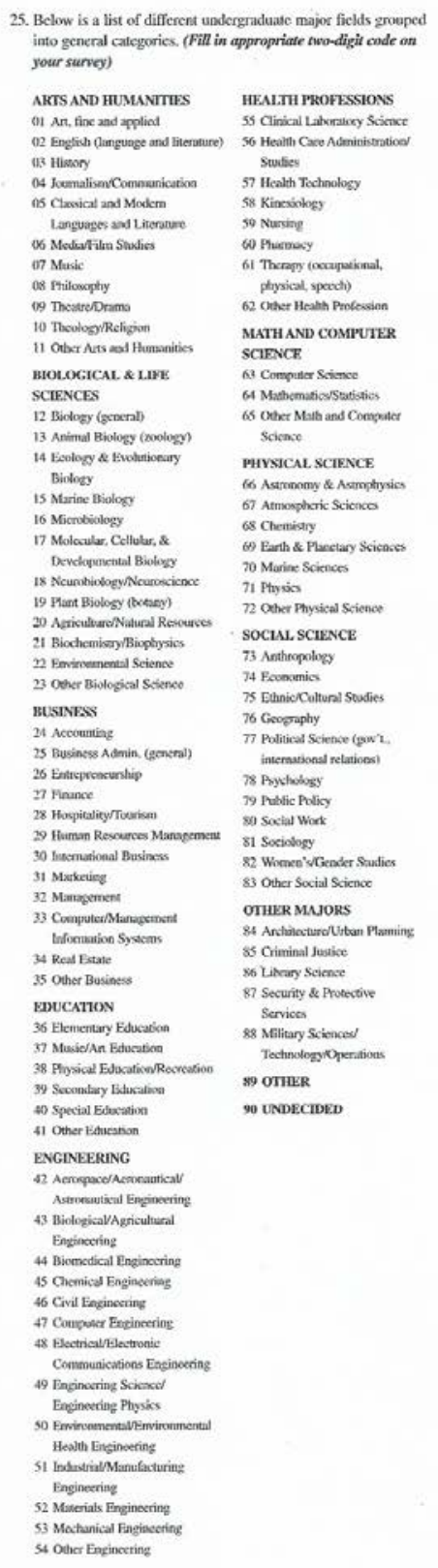

5. Bclow is a list of different undergraduate major ficlds grouped sour survey

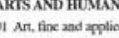

Toulug Reliojom

Oblar Aits wol Huma

Bingeng (omats

Animal Biology (zoologen)

De-vedopunctal Biolvegy

monuter/Mantagem

Elementary Edw

Scoondary Eduradion

Ther loveron

Conposer Exrioneris

Communiceations Eneinoers

Eninume Phoiks

44 OAkr Enginering

Turn over for Question 26

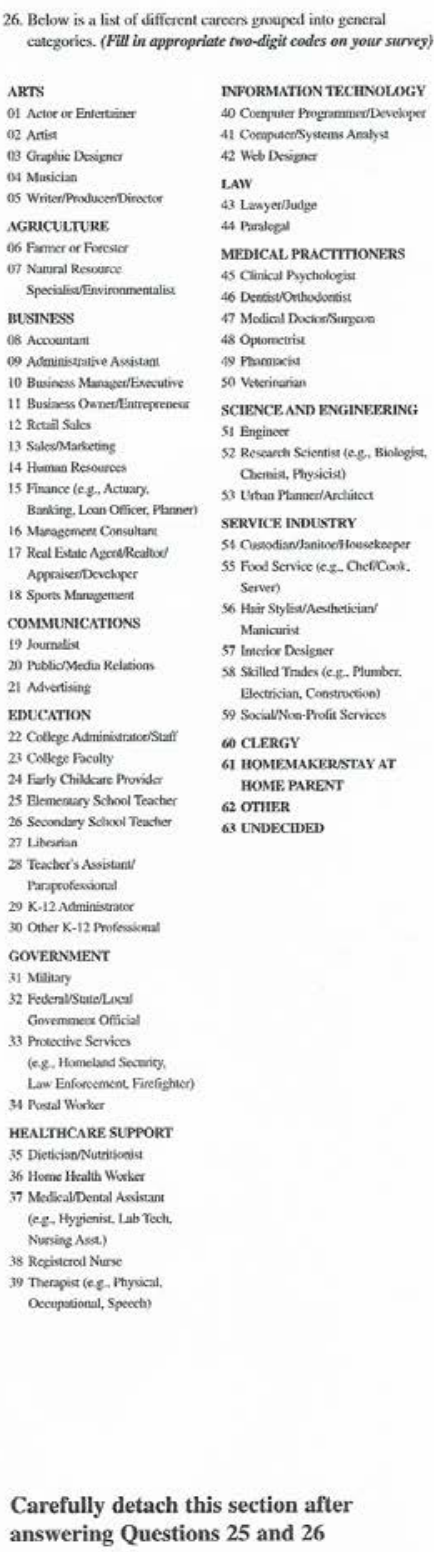

Carefully detach this section after answering Questions 25 and 26 


\section{Appendix B: List of 2015 TFS Participating Institutions}

(Note: Stratification Cell column identifies the classification of the institution for purposes of this dissertation. HBCUs have Stratification Cell codes 34, 35, 38, 39, 40, and 41.)

\begin{tabular}{|c|c|c|c|c|c|}
\hline ACE & Institution & City & State & $\begin{array}{c}\begin{array}{c}\text { Stratification } \\
\text { Cell }\end{array} \\
\end{array}$ & $\begin{array}{c}\text { Included in } \\
\text { National Norms }\end{array}$ \\
\hline 1243 & Adrian College & Adrian & MI & 21 & Yes \\
\hline 1 & Alabama A \& M University & Normal & AL & 34 & No \\
\hline 354 & Albertus Magnus College & New Haven & $\mathrm{CT}$ & 16 & No \\
\hline 1244 & Albion College & Albion & $\mathrm{MI}$ & 23 & Yes \\
\hline 2232 & Albright College & Reading & PA & 22 & Yes \\
\hline 2233 & Allegheny College & Meadville & PA & 23 & No \\
\hline 1245 & Alma College & Alma & MI & 23 & Yes \\
\hline 414 & American University & Washington & DC & 5 & No \\
\hline 1135 & Amherst College & Amherst & MA & 14 & Yes \\
\hline 2432 & Anderson University & Anderson & SC & 22 & Yes \\
\hline 2046 & Antioch College & Yellow Springs & $\mathrm{OH}$ & 11 & No \\
\hline 2235 & Arcadia University & Glenside & PA & 23 & No \\
\hline 125 & Art Center College of Design & Pasadena & CA & 12 & No \\
\hline 1322 & Augsburg College & Minneapolis & MN & 22 & Yes \\
\hline 599 & Aurora University & Aurora & IL & 12 & No \\
\hline 1141 & Babson College & Wellesley & MA & 14 & Yes \\
\hline 454 & Barry University & Miami & FL & 4 & No \\
\hline 1042 & Bates College & Lewiston & $M E$ & 14 & Yes \\
\hline 5275 & Bay Path College & Longmeadow & MA & 11 & No \\
\hline 2519 & Belmont University & Nashville & TN & 23 & No \\
\hline 2931 & Beloit College & Beloit & WI & 14 & Yes \\
\hline 7072 & Benedictine College & Atchison & KS & 18 & No \\
\hline 692 & Benedictine University & Lisle & IL & 4 & Yes \\
\hline 1934 & Bennett College for Women & Greensboro & NC & 38 & No \\
\hline 503 & Berry College & Mount Berry & GA & 13 & Yes \\
\hline 5349 & Bethany Lutheran Coliege & Mankato & MN & 23 & Yes \\
\hline 5753 & Biola University & La Mirada & CA & 4 & Yes \\
\hline 1641 & Bloomfield College & Bloomfield & NJ & 20 & No \\
\hline 2049 & Bluffton University & Bluffton & $\mathrm{OH}$ & 21 & Yes \\
\hline 1142 & Boston College & Chestnut Hill & MA & 5 & Yes \\
\hline 1193 & Bridgewater State University & Bridgewater & MA & 8 & Yes \\
\hline 2404 & Brown University & Providence & RI & 6 & No \\
\hline 5622 & Bryant University & Smithfield & RI & 13 & No \\
\hline 2236 & Bryn Mawr College & Bryn Mawr & PA & 14 & No \\
\hline 131 & California Baptist University & Riverside & CA & 20 & No \\
\hline 4893 & California State University-Channel Islands & Camarillo & CA & 7 & No \\
\hline 142 & California State University-Chico & Chico & CA & 9 & No \\
\hline 5010 & California State University-Long Beach & Long Beach & CA & 8 & Yes \\
\hline 230 & California State University-Northridge & Northridge & CA & 7 & Yes \\
\hline 4851 & California State University-San Marcos & San Marcos & CA & 7 & No \\
\hline 1327 & Carleton College & Northfield & MN & 14 & Yes \\
\hline 606 & Carthage College & Kenosha & WI & 23 & Yes \\
\hline 1938 & Catawba College & Salisbury & NC & 11 & Yes \\
\hline 416 & Catholic University of America & Washington & DC & 4 & No \\
\hline 1745 & Cazenovia College & Cazenovia & NY & 11 & Yes \\
\hline 2054 & Central State University & Wilberforce & $\mathrm{OH}$ & 34 & Yes \\
\hline 141 & Chapman University & Orange & CA & 23 & Yes \\
\hline 2240 & Chatham University & Pittsburgh & PA & 13 & Yes \\
\hline 2322 & Cheyney University of Pennsylvania & Cheyney & PA & 34 & No \\
\hline 1941 & Chowan University & Murfreesboro & NC & 20 & Yes \\
\hline 2523 & Christian Brothers University & Memphis & TN & 18 & No \\
\hline 2435 & Citadel Military College of South Carolina & Charleston & SC & 9 & Yes \\
\hline 507 & Clark Atlanta University & Atlanta & GA & 41 & Yes \\
\hline 1151 & Clark University & Worcester & MA & 5 & Yes \\
\hline
\end{tabular}


Institutions Participating in the 2015 CIRP Freshman Survey

\begin{tabular}{|c|c|c|c|c|c|}
\hline ACE & Institution & City & State & $\begin{array}{c}\text { Stratification } \\
\text { Cell } \\
\end{array}$ & $\begin{array}{c}\text { Included in } \\
\text { National Norms } \\
\end{array}$ \\
\hline 1044 & Colby College & Waterville & ME & 14 & Yes \\
\hline 1752 & College of Mount Saint Vincent & Bronx & NY & 16 & No \\
\hline 1152 & College of the Holy Cross & Worcester & MA & 18 & Yes \\
\hline 7402 & Colorado Christian University & Lakewood & co & 22 & Yes \\
\hline 319 & Colorado College & Colorado Springs & $\mathrm{CO}$ & 14 & Yes \\
\hline 321 & Colorado School of Mines & Golden & $\mathrm{co}$ & 3 & No \\
\hline 318 & Colorado State University-Fort Collins & Fort Collins & $\mathrm{CO}$ & 2 & No \\
\hline 359 & Connecticut College & New London & $\mathrm{CT}$ & 14 & No \\
\hline 1763 & Cornell University & Ithaca & NY & 6 & No \\
\hline 5821 & Covenant College & Lookout Mountain & GA & 23 & No \\
\hline 1573 & Creighton University & Omaha & NE & 18 & Yes \\
\hline 6430 & CUNY Lehman College & Bronx & NY & 8 & Yes \\
\hline 7254 & CUNY Medgar Evers College & Brooklyn & NY & 7 & No \\
\hline 6166 & Dalton State College & Dalton & GA & 7 & No \\
\hline 2244 & Delaware Valley College & Doylestown & PA & 12 & Yes \\
\hline 5882 & DeSales University & Center Valley & PA & 17 & No \\
\hline 2247 & Dickinson College & Carlisle & PA & 14 & Yes \\
\hline 1005 & Dillard University & New Orleans & LA & 38 & No \\
\hline 687 & Dominican University & River Forest & IL & 17 & Yes \\
\hline 1943 & Duke University & Durham & NC & 6 & No \\
\hline 753 & Earlham College & Richmond & IN & 23 & Yes \\
\hline 2845 & Eastern Washington University & Cheney & WA & 7 & No \\
\hline 464 & Eckerd College & Saint Petersburg & $\mathrm{FL}$ & 23 & Yes \\
\hline 5105 & Embry-Riddle Aeronautical University-Daytona Beach & Daytona Beach & FL & 13 & No \\
\hline 1158 & Emmanuel College & Boston & MA & 17 & Yes \\
\hline 2787 & Emory \& Henry College & Emory & VA & 20 & Yes \\
\hline 511 & Emory University & Atlanta & GA & 6 & Yes \\
\hline 362 & Fairfield University & Fairfield & $\mathrm{CT}$ & 18 & Yes \\
\hline 6529 & Fairleigh Dickinson University-College at Florham & Madison & NJ & 12 & Yes \\
\hline 2788 & Ferrum College & Ferrum & VA & 20 & No \\
\hline 463 & Florida State University & Tallahassee & $\mathrm{FL}$ & 2 & Yes \\
\hline 1773 & Fordham University & Bronx & NY & 5 & Yes \\
\hline 5414 & Franklin Pierce University & Rindge & NH & 11 & Yes \\
\hline 897 & Friends University & Wichita & KS & 12 & Yes \\
\hline 2446 & Furman University & Greenville & SC & 14 & Yes \\
\hline 961 & Georgetown College & Georgetown & KY & 23 & Yes \\
\hline 421 & Georgetown University & Washington & DC & 6 & No \\
\hline 515 & Georgia Institute of Technology-Main Campus & Atlanta & GA & 3 & Yes \\
\hline 519 & Georgia Southern University & Statesboro & GA & 2 & No \\
\hline 2263 & Gettysburg College & Gettysburg & PA & 14 & Yes \\
\hline 5199 & Grace College and Theological Seminary & Winona Lake & IN & 21 & Yes \\
\hline 1006 & Grambling State University & Grambling & LA & 34 & Yes \\
\hline 641 & Greenville College & Greenville & IL & 21 & No \\
\hline 834 & Grinnell College & Grinnell & IA & 14 & Yes \\
\hline 1953 & Guilford College & Greensboro & NC & 22 & Yes \\
\hline 1338 & Gustavus Adolphus College & Saint Peter & MN & 23 & Yes \\
\hline 1776 & Hamilton College & Clinton & NY & 14 & No \\
\hline 7022 & Hampshire College & Amherst & MA & 14 & No \\
\hline 9107 & Harrisburg University of Science and Technology & Harrisburg & PA & 11 & No \\
\hline 1777 & Hartwick College & Oneonta & NY & 13 & Yes \\
\hline 180 & Harvey Mudd College & Claremont & CA & 14 & Yes \\
\hline
\end{tabular}


Institutions Participating in the 2015 CIRP Freshman Survey

\begin{tabular}{|c|c|c|c|c|c|}
\hline ACE & Institution & City & State & $\begin{array}{c}\text { Stratification } \\
\text { Cell }\end{array}$ & $\begin{array}{c}\text { Included in } \\
\text { National Norms }\end{array}$ \\
\hline 2267 & Haverford College & Haverford & PA & 14 & Yes \\
\hline 2072 & Hiram College & Hiram & $\mathrm{OH}$ & 12 & Yes \\
\hline 1755 & Hobart William Smith Colleges & Geneva & NY & 14 & Yes \\
\hline 2794 & Hollins University & Roanoke & VA & 13 & Yes \\
\hline 152 & Holy Names University & Oakland & CA & 16 & Yes \\
\hline 424 & Howard University & Washington & DC & 41 & Yes \\
\hline 8 & Huntingdon College & Montgomery & AL & 20 & Yes \\
\hline 762 & Huntington University & Huntington & IN & 22 & No \\
\hline 642 & Illinois College & Jacksonville & IL & 22 & Yes \\
\hline 7813 & Institute of American Indian and Alaska Native Culture & Santa Fe & NM & 7 & Yes \\
\hline 1785 & Iona College & New Rochelle & NY & 16 & Yes \\
\hline 91 & John Brown University & Siloam Springs & AR & 14 & Yes \\
\hline 1956 & Johnson C. Smith University & Charlotte & NC & 35 & Yes \\
\hline 2272 & Juniata College & Huntingdon & PA & 13 & No \\
\hline 1272 & Kalamazoo College & Kalamazoo & MI & 14 & Yes \\
\hline 1617 & Keene State College & Keene & NH & 8 & Yes \\
\hline 652 & Knox College & Galesburg & IL & 14 & Yes \\
\hline 523 & LaGrange College & Lagrange & GA & 21 & Yes \\
\hline 653 & Lake Forest College & Lake Forest & IL & 14 & No \\
\hline 2947 & Lawrence University & Appleton & WI & 14 & Yes \\
\hline 1794 & Le Moyne College & Syracuse & NY & 17 & Yes \\
\hline 2277 & Lebanon Valley College & Annville & PA & 22 & Yes \\
\hline 2194 & Lewis \& Clark College & Portland & OR & 14 & Yes \\
\hline 7448 & LIM College & New York & NY & 11 & Yes \\
\hline 2539 & Lincoln Memorial University & Harrogate & TN & 13 & Yes \\
\hline 2279 & Lincoln University of Pennsylvania & Lincoln University & PA & 34 & Yes \\
\hline 2195 & Linfield College-McMinnville Campus & McMinnville & OR & 23 & No \\
\hline 2796 & Longwood University & Farmville & VA & 8 & No \\
\hline 1961 & Louisburg College & Lousiburg & NC & 31 & No \\
\hline 657 & Loyola University Chicago & Chicago & IL & 5 & Yes \\
\hline 1086 & Loyola University Maryland & Baltimore & MD & 18 & Yes \\
\hline 841 & Luther College & Decorah & IA & 23 & Yes \\
\hline 2283 & Lycoming College & Williamsport & PA & 22 & Yes \\
\hline 1344 & Macalester College & Saint Paul & $\mathrm{MN}$ & 23 & Yes \\
\hline 769 & Manchester University & North Manchester & IN & 21 & No \\
\hline 1796 & Manhattan College & Riverdale & NY & 18 & Yes \\
\hline 2801 & Mary Baldwin College & Staunton & VA & 20 & No \\
\hline 1275 & Marygrove College & Detroit & MI & 16 & Yes \\
\hline 2543 & Maryville College & Maryville & TN & 23 & Yes \\
\hline 1496 & Maryville University of Saint Louis & Saint Louis & MO & 4 & Yes \\
\hline 1963 & Meredith College & Raleigh & NC & 12 & Yes \\
\hline 2290 & Messiah College & Mechanicsburg & PA & 23 & Yes \\
\hline 1278 & Michigan Technological University & Houghton & MI & 3 & No \\
\hline 2633 & Midwestern State University & Wichita Falls & TX & 8 & Yes \\
\hline 199 & Mills College & Oakland & CA & 13 & Yes \\
\hline 1412 & Millsaps College & Jackson & MS & 23 & Yes \\
\hline 2289 & Moravian College and Moravian Theological Seminary & Bethlehem & PA & 22 & Yes \\
\hline 5796 & Morehouse College & Atlanta & GA & 35 & Yes \\
\hline 1094 & Morgan State University & Baltimore & MD & 40 & No \\
\hline 844 & Morningside College & Sioux City & IA & 23 & Yes \\
\hline 1096 & Mount St. Mary's University & Emmitsburg & MD & 17 & Yes \\
\hline
\end{tabular}


Institutions Participating in the 2015 CIRP Freshman Survey

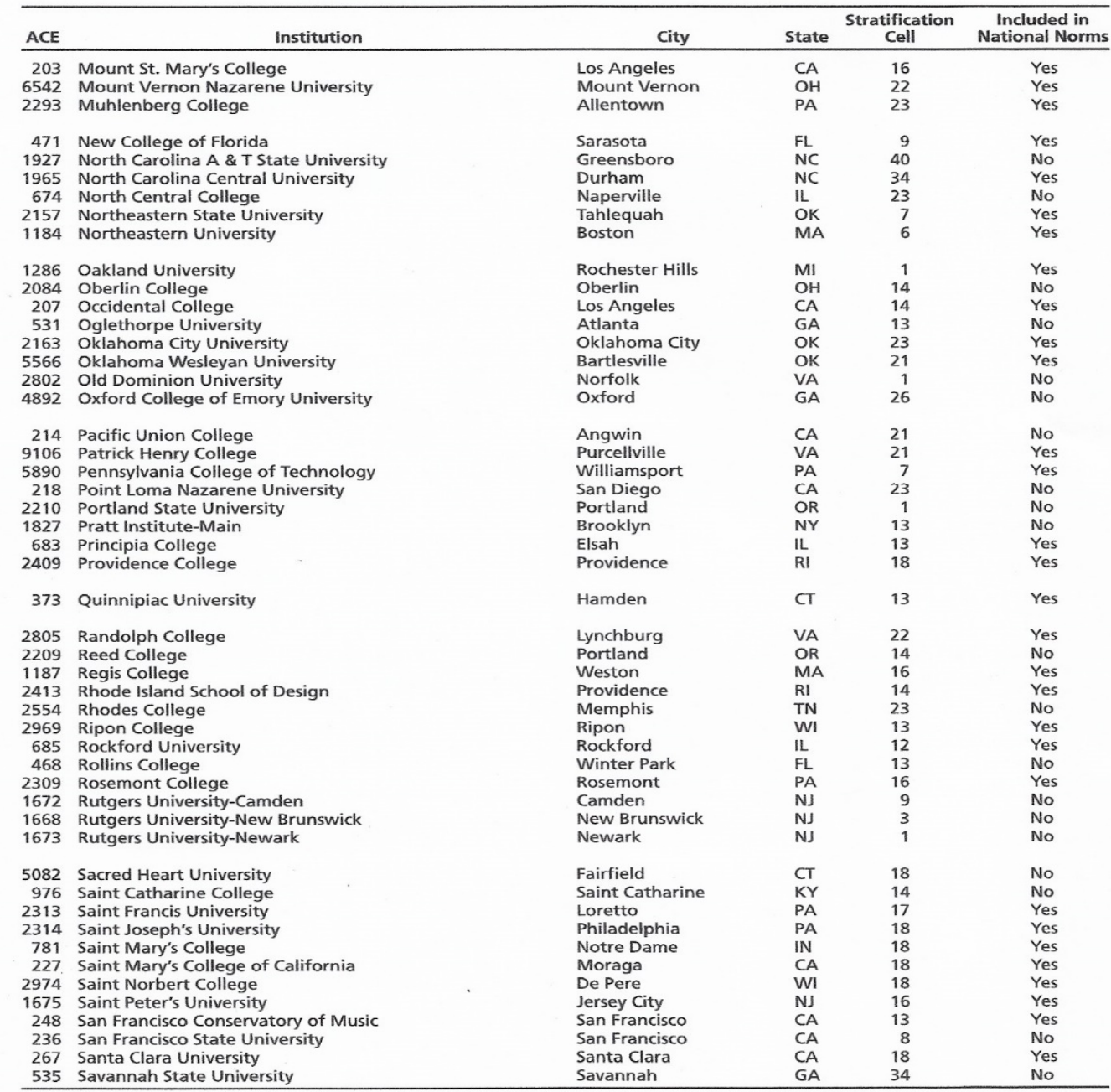


Institutions Participating in the 2015 CIRP Freshman Survey

\begin{tabular}{|c|c|c|c|c|c|}
\hline ACE & Institution & City & State & $\begin{array}{c}\text { Stratification } \\
\text { Cell }\end{array}$ & $\begin{array}{c}\text { Included in } \\
\text { National Norms }\end{array}$ \\
\hline 693 & School of the Art Institute of Chicago & Chicago & IL & 13 & Yes \\
\hline 2857 & Seattle Pacific University & Seattle & WA & 23 & Yes \\
\hline 2858 & Seattle University & Seattle & WA & 18 & No \\
\hline 1676 & Seton Hall University & South Orange & NJ & 4 & Yes \\
\hline 2564 & Sewanee-The University of the South & Sewanee & $\mathrm{TN}$ & 23 & No \\
\hline 1836 & Siena College & Loudonville & NY & 18 & No \\
\hline 2944 & Silver Lake College of the Holy Family & Manitowoc & Wl & 16 & Yes \\
\hline 1188 & Simmons College & Boston & MA & 13 & Yes \\
\hline 1189 & Smith College & Northampton & MA & 14 & No \\
\hline 170 & Sonoma State University & Rohnert Park & CA & 8 & No \\
\hline 2553 & Southern Adventist University & Collegedale & TN & 21 & No \\
\hline 2657 & Southern Methodist University & Dallas & $\mathrm{TX}$ & 5 & No \\
\hline 2664 & Southwestern University & Georgetown & TX & 23 & Yes \\
\hline 502 & Spelman College & Atlanta & GA & 35 & No \\
\hline 1846 & St. Lawrence University & Canton & NY & 14 & Yes \\
\hline 5398 & St. Louis College of Pharmacy & St. Louis & MO & 11 & Yes \\
\hline 1949 & St. Andrews University & Laurinburg & NC & 20 & Yes \\
\hline 2648 & St. Mary's University & San Antonio & TX & 17 & Yes \\
\hline 5498 & St. Thomas Aquinas College & Sparkill & NY & 11 & Yes \\
\hline 473 & Stetson University & DeLand & $\mathrm{FL}$ & 13 & Yes \\
\hline 1110 & Stevenson University & Stevenson & MD & 11 & Yes \\
\hline 25 & Stillman College & Tuscaloosa & $\mathrm{AL}$ & 38 & No \\
\hline 1204 & Suffolk University & Boston & MA & 12 & Yes \\
\hline 7028 & SUNY at Purchase College & Purchase & NY & 9 & No \\
\hline 4894 & SUNY Institute of Technology at Utica-Rome & Utica & NY & 9 & Yes \\
\hline 2336 & Swarthmore College & Swarthmore & PA & 14 & No \\
\hline 2675 & Texas Christian University & Fort Worth & $\operatorname{TX}$ & 5 & No \\
\hline 2063 & The College of Wooster & Wooster & $\mathrm{OH}$ & 14 & Yes \\
\hline 476 & The University of Tampa & Tampa & $\mathrm{FL}$ & 12 & Yes \\
\hline 2692 & The University of Texas at El Paso & El Paso & TX & 1 & No \\
\hline 7256 & Touro College & New York & NY & 12 & No \\
\hline 379 & Trinity College & Hartford & $\mathrm{CT}$ & 14 & No \\
\hline 2685 & Trinity University & San Antonio & TX & 23 & Yes \\
\hline 435 & Trinity Washington University & Washington & DC & 16 & No \\
\hline 24 & Troy University & Troy & $\mathrm{AL}$ & 8 & No \\
\hline 1024 & Tulane University of Louisiana & New Orleans & LA & 6 & Yes \\
\hline 341 & United States Air Force Academy & USAFA & $\mathrm{CO}$ & 9 & Yes \\
\hline 380 & United States Coast Guard Academy & New London & $\mathrm{CT}$ & 9 & Yes \\
\hline 1893 & United States Military Academy & West Point & NY & 9 & Yes \\
\hline 48 & University of Alaska-Fairbanks & Fairbanks & AK & 1 & No \\
\hline 76 & University of Arkansas at Pine Bluff & Pine Bluff & AR & 34 & Yes \\
\hline 382 & University of Bridgeport & Bridgeport & $\mathrm{CT}$ & 11 & Yes \\
\hline 257 & University of California-Los Angeles & Los Angeles & CA & 3 & Yes \\
\hline 262 & University of California-Riverside & Riverside & CA & 1 & No \\
\hline 260 & University of California-San Diego & La Jolla & CA & 3 & Yes \\
\hline 259 & University of California-Santa Barbara & Santa Barbara & CA & 3 & No \\
\hline 1456 & University of Central Missouri & Warrensburg & MO & 8 & No \\
\hline 1276 & University of Detroit Mercy & Detroit & MI & 18 & Yes \\
\hline 567 & University of Hawaii at Manoa & Honolulu & $\mathrm{HI}$ & 1 & Yes \\
\hline 9109 & University of Hawaii-West Oahu & Kapolei & $\mathrm{HI}$ & 7 & Yes \\
\hline 584 & University of Idaho & Moscow & ID & 1 & Yes \\
\hline 704 & University of Illinois at Urbana-Champaign & Champaign & IL & 3 & No \\
\hline 6086 & University of Maryland-Baltimore County & Baltimore & MD & 2 & Yes \\
\hline 1207 & University of Massachusetts Amherst & Amherst & MA & 2 & Yes \\
\hline
\end{tabular}


Institutions Participating in the 2015 CIRP Freshman Survey

\begin{tabular}{|c|c|c|c|c|c|}
\hline ACE & Institution & City & State & $\begin{array}{c}\text { Stratification } \\
\text { Cell }\end{array}$ & $\begin{array}{c}\text { Included in } \\
\text { National Norms }\end{array}$ \\
\hline 5773 & University of Massachusetts-Dartmouth & North Dartmouth & MA & 9 & No \\
\hline 1294 & University of Michigan-Ann Arbor & Ann Arbor & MI & 3 & Yes \\
\hline 6400 & University of Michigan-Flint & Flint & $\mathrm{MI}$ & 9 & No \\
\hline 1984 & University of North Carolina at Chapel Hill & Chapel Hill & NC & 3 & Yes \\
\hline 2031 & University of North Dakota & Grand Forks & ND & 1 & Yes \\
\hline 322 & University of Northern Colorado & Greeley & $\mathrm{CO}$ & 1 & Yes \\
\hline 785 & University of Notre Dame & Notre Dame & IN & 6 & Yes \\
\hline 2212 & University of Oregon & Eugene & OR & 2 & No \\
\hline 2341 & University of Pennsylvania & Philadelphia & PA & 6 & No \\
\hline 6232 & University of Pittsburgh-Bradford & Bradford & PA & 8 & Yes \\
\hline 2342 & University of Pittsburgh-Pittsburgh Campus & Pittsburgh & PA & 2 & Yes \\
\hline 2844 & University of Puget Sound & Tacoma & WA & 14 & Yes \\
\hline 265 & University of Redlands & Redlands & CA & 13 & Yes \\
\hline 1889 & University of Rochester & Rochester & NY & 5 & Yes \\
\hline 374 & University of Saint Joseph & West Hartford & $\mathrm{CT}$ & 17 & Yes \\
\hline 2458 & University of South Carolina-Columbia & Columbia & SC & 3 & No \\
\hline 9119 & University of South Florida Sarasota-Manatee & Sarasota & $\mathrm{FL}$ & 9 & Yes \\
\hline 268 & University of Southern California & Los Angeles & CA & 6 & No \\
\hline 157 & University of the Pacific & Stockton & CA & 4 & Yes \\
\hline 2104 & University of Toledo & Toledo & $\mathrm{OH}$ & 1 & No \\
\hline 2764 & University of Vermont & Burlington & VT & 2 & Yes \\
\hline 787 & Valparaiso University & Valparaiso & IN & 23 & Yes \\
\hline 2567 & Vanderbilt University & Nashville & $\mathrm{TN}$ & 6 & Yes \\
\hline 5053 & Vanguard University of Southern California & Costa Mesa & CA & 20 & No \\
\hline 1891 & Vassar College & Poughkeepsie & NY & 14 & Yes \\
\hline 5517 & Villa Maria College & Buffalo & NY & 16 & Yes \\
\hline 2347 & Villanova University & Villanova & PA & 18 & Yes \\
\hline 2828 & Virginia Union University & Richmond & VA & 38 & No \\
\hline 2459 & Voorhees College & Denmark & SC & 38 & No \\
\hline 789 & Wabash College & Crawfordsville & IN & 13 & Yes \\
\hline 5562 & Walsh University & North Canton & $\mathrm{OH}$ & 17 & Yes \\
\hline 2214 & Warner Pacific College & Portland & OR & 20 & Yes \\
\hline 1988 & Warren Wilson College & Swannanoa & NC & 13 & Yes \\
\hline 2829 & Washington and Lee University & Lexington & VA & 14 & No \\
\hline 7023 & Wayne County Community College District & Detroit & MI & 26 & No \\
\hline 1588 & Wayne State College & Wayne & NE & 8 & No \\
\hline 1295 & Wayne State University & Detroit & MI & 1 & Yes \\
\hline 1895 & Wells College & Aurora & NY & 12 & Yes \\
\hline 384 & Wesleyan University & Middletown & $\mathrm{CT}$ & 14 & Yes \\
\hline 5035 & Western New England University & Springfield & MA & 12 & Yes \\
\hline 2352 & Westminster College & New Wilmington & PA & 22 & Yes \\
\hline 707 & Wheaton College & Wheaton & IL & 23 & No \\
\hline 2867 & Whitman College & Walla Walla & WA & 14 & Yes \\
\hline 2297 & Widener University-Main Campus & Chester & PA & 4 & No \\
\hline 2354 & Wilkes University & Wilkes-Barre & PA & 12 & Yes \\
\hline 2215 & Willamette University & Salem & OR & 14 & Yes \\
\hline 2355 & Wilson College & Chambersburg & PA & 20 & Yes \\
\hline 1992 & Wingate University & Wingate & NC & 12 & Yes \\
\hline 1993 & Winston-Salem State University & Winston-Salem & NC & 34 & Yes \\
\hline 1026 & Xavier University of Louisiana & New Orleans & LA & 39 & Yes \\
\hline 2359 & York College Pennsylvania & York & PA & 13 & No \\
\hline
\end{tabular}




\section{CURRICULUM VITAE}

Vickie G. Bridgeman

\section{SUMMARY of QUALIFICATIONS \\ Counseling and Advising Skills}

- Provide academic counseling and advising services to prospective and currently enrolled students regarding Baccalaureate degree programs as well as Masters in Teaching

- Assist students with class scheduling, registration, admissions, petitioning process, careers and majors, academic difficulties and individualized academic plans

- Refer students to Tutoring and other support services

- Supervised and coordinated peer advising program and graduated assistants, which included recruitment and training needs

- Attended meetings, seminars, and training to learn new skills to better serve students

- Experienced in the provision of counseling to a wide student population including; traditional and non-traditional, at-risk, exploratory/undecided students, persons with disabilities, and members of numerous cultural backgrounds

\section{Administrative and Organizational Skills}

- Supervised academic counselors/academic specialists, academic coaches. support staff, graduate interns and student workers

- Responsible for overseeing the daily operation of several support centers

- Responsible for support staff yearly evaluations

- Responsible for assigning projects to support staff, graduate/interns and student workers

- Coordinated academic fairs and special diversity events

- Created academic forms, brochures for office use and recruiting

- Conducted degree clearances

- Determined eligibility for student awards

- Coordinated college transfer manual published by the Provost office

- Coordinated, develop and assess new programs for at-risk and special groups

- Compiled data and produced analytical statistical reports

- Coordinated and developed potential retention strategies for at-risk and special groups

- Coordinated Undergraduate Affairs Freshmen Orientation 
- Coordinated Career Discovery workshops

- Assisted with preparing annual reports for REACH and Cultural Center

\section{Customer Service and Public Relations Skills}

- Served as liaison with designed department and centers

- Presented at special programs and events

- Provided follow up service to applicants with special request in an efficient and effective manner

- Represented department/school/center at various University-wide events

- Greet students and parents at Welcome Week and other university events

\section{Work Experience}

\section{University of Louisville}

2017

Interim Director, Cultural Center

2017

Associate Director, Cultural Center

2017

Director, REACH Academic Development

2014

Director of Undergraduate Studies, Advising

2005

Academic Counselor, Sr., REACH

2003

Academic Counselor II, School of Education

2000

Academic Counselor II, Division of Transitional Studies 1998

Admissions Counselor, Admissions Office 1995

Program Assistant II, Housing and Residence Life 1993

Lab Assistant, School of Dentistry

1987
Feb. 1986 to May

Feb. 2017 to May

Aug. 2014 to Feb.

July 2005 to Aug.

Oct. 2003 to July

May 2000 to Oct.

May 1998 to May

Aug. 1995 to May

May 1993 to Aug.

April 1987 to May

Feb. 1986 to April

\section{Education}

University of Louisville

PhD- Educational Leadership and Organizational Development, May 2021

Master of Arts - Higher Education, May 2002

Master of Education- Counseling and Psychology, May 1993

Bachelor of Science- Sociology, December 1985

Associate in Arts - Social Science, December 1983 